\title{
Vegetation of the Hixon Columbian Sharp-Tailed Grouse Habitat Management Plan Area, Washington County, Idaho
}

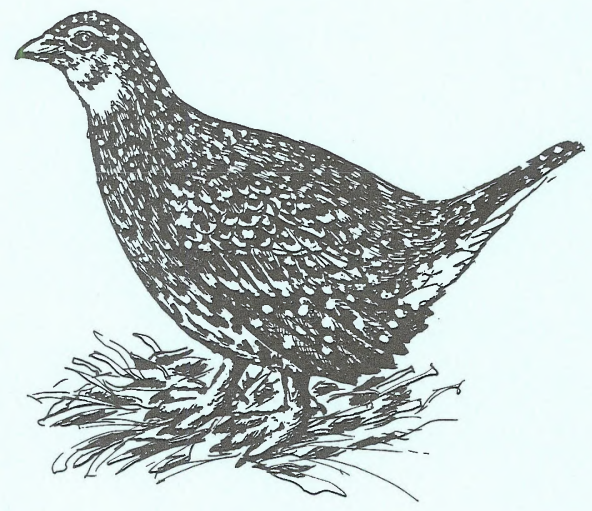


by

Michsel Mancuso and Robert Moseley

Conservation Dan Center

February 1997

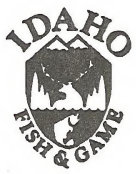

Idaho Department of Fish and Game Natural Resource Policy Bureau 600 South Walnut, P.O. Box 25

Boise, Idaho 83707

Stephen Mealey, Director

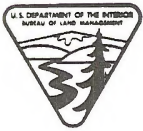

Challenge Cost-share Report Preparod for:

Bureau of Land Management

Lower Snake River District

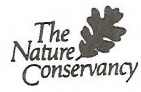

Cascade Resource Area 


\section{Abstract}

The Hixon Columbian Sharp-tailed Grouse Habitat Management Plan Area supports the largest and one of the last known populations of Columbian sharp-tailed grouse (Tympanuchus phasianellus columbianus) in western Idaho. The Bureau of Land Management manages the 27,740 acre area cooperatively with the Idaho Department of Fish and Game and The Naure Conservancy. The need for a vegetation map of the area to help land managers had been previously identified. Our primary objective was to inventory, classify, and map the distribution of plant communities of the Habitat Management Plan area.

We identfied 24 plant community types within the project area, several of which are either poorly or undescribed in regional classifications. We conducted a limited amount of vegetation sampling to help characterize the composition and structure of some of the community types. Classification for the vegetation map is based on 13 cover types grouped into six habitat classes - sagebrush, grassland, scabland, mountain shrub, conifer forest, and riparian. The most common cover type is xeric sagebrush, covering roughly $34 \%$ of the project area. It is followed by the rock buckwheat $(24 \%)$, bluebunch wheatgrass $(17 \%)$, mountain shrub $(9 \%)$, and bulbous bluegrass $(7 \%)$ cover types. Each of the other eight cover types provide less than $5 \%$ coverage. We also assigned ecological condition ranks to selected cover types. The vegetation map is comprised of 154 polygons, ranging in size from about 1,879 to 8 acres, with a mean of 177 acres. The vegetation map is in both a GIS and non-GIS format at a scale of $1: 24,000$.

Two populations of squawapple (Peraphyllum ramosissimum), a BLM Sensitive plant species were revisited and information about them updated. No new populations of squawapple or other rare plants were discovered. We also updated vegetation information and assessed the conservation status of Bucliwheat Flats Research Natural Area (RNA).

\section{Acknowledgments}

We would like to thank Jack LaRocco for his initiation and support of this project. We also thank Linda Williams and Andrew Pimer for their help with the vegetation sampling, and Lawrence Hartpence for producing the GIS-generated vegetation map. The Nature Conservancy provided funding for digitization and production of the GIS version of the vegetation map. 


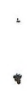




\section{Table of contents}

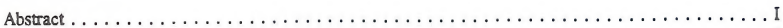

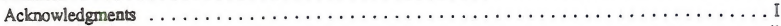

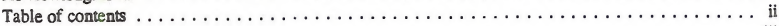

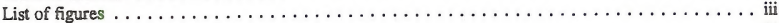

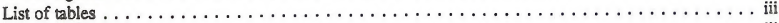

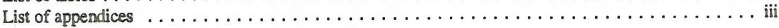

The Hixon Columbian sharp-tailed grouse Habitat Management Plan Area

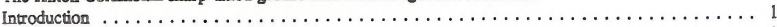

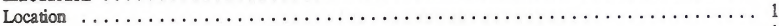

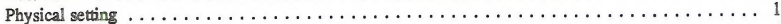

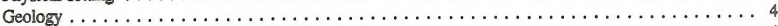

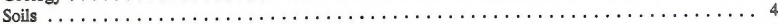

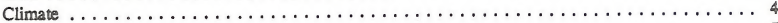

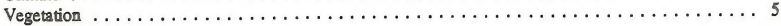

\section{A vegetation map for the Hixon Columbian sharp-tailed grouse Habitat Management Plan Area}

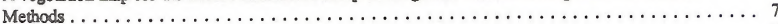

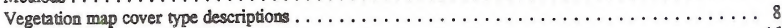

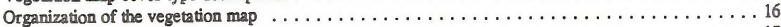

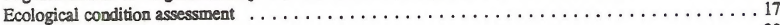

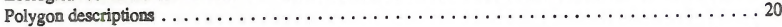

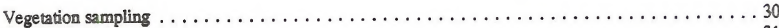

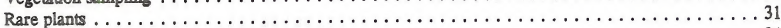

Buckwheat Flats Research Natural Area . . . . . . . . . . . . . . . . . . . . . . . 34

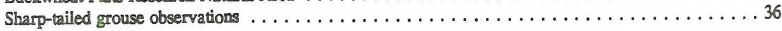

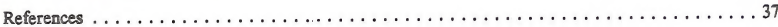




\section{List of figures}

Figure 1 Location of the HMP Area in Idaho $\ldots \ldots \ldots \ldots \ldots \ldots \ldots \ldots \ldots \ldots$

Figure 2. General location and boundaries of the HMP Area $\ldots \ldots \ldots \ldots \ldots \ldots \ldots \ldots$

Figure 3. Locations of Peraphyllum ramosissimun within the HMP Area $\ldots \ldots \ldots \ldots \ldots \ldots$

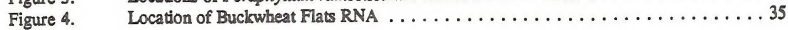

List of tables

Table 1. Plant community types occurring within the HMP Area $\ldots \ldots \ldots \ldots \ldots \ldots$

Table 2. Cover types for the HMP Area vegetation $\operatorname{map} \ldots \ldots \ldots \ldots \ldots \ldots \ldots \ldots \ldots$

Table 3. Cover type frequencies for the HMP Area vegetation map . . . . . . . . . 18

Table 4. Total and relative extent, and average polygon size for the vegetation map cover types 19

Table 5. Plant community types sampled in the HMP Area $\ldots \ldots \ldots \ldots \ldots \ldots \ldots \ldots$

\section{List of appendices}

Appendix 1. Locations of leafy spurge (Euphorbia esula) within the HMP Area.

Appendix 2. Size, cover type, inclusions, and ecological condition summary for the vegetation map polygons.

Appendix 3. Average cover and constancy values for six community types in the HMP Area.

Appendix 4. Location of vegetation plots in the HMP Ares.

Appendix 5. Western Heritage Task Force plot forms II and III.

Appendix 6. Element Occurrence Records for Peraphyllum ramosissimum in the HMP Area.

Appendix 7. Location of sharp-tailed grouse observations in the HMP Area. 
' 


\section{Introduction}

The Hixon Columbian Sharp-tailed Grouse Habitat Management Plan Area (HMP Area) supports the largest and one of the last known populations of Columbian sharp-bailed grouse (Iympanuchus phasianellus columbianus) in western Idaho. The grouse is a Bureau of Land Management (BLM) Sensitive Species, an Idaho Department of Fish and Game (IDFG) Species of Special Concern, and on the U.S. Fish and Wildife Service's Species of Concern list (Conservation Data Center 1996). The BLM manages the HMP Area cooperatively with the IDFG and The Nawre Conservancy (TNC). The primary cooperative objectives are to manage the HMP Area for good to excellent babitat conditions and a corresponding population of 300-400 Columbian sharp-tailed grouse (Bureau of Land Management 1994). The population has maintained a spring count of approximately 100 birds over the past several years.

The BLM completed its Hixon Columbian Sharp-tailed Grouse Habitat Management Plan in 1994 (Bureau of Land Management 1994). One of the planned actions scheduled for 1996 was to produce a vegetation map for the HMP Area. To satisfy this planned action, the BLM and the IDFG's Conservation Datn Center $(C D C)$ entered into a cooperative Challenge Cost-share agreement. Our primary objective was to inventory, classify, and map the distribution of plant communities within the HMP Area.

A coarse-scale vegetation map was completed for the southeastern corner of the HMP Area in 1987 as part of a Columbian sharp-tailed grouse habitat selection study (Marks and Marks 1987). A complete and finerscale vegetation map for the HMP Area is necessary to belp implement management decisions concordant with the HMP goals of improving sharp-tailed grouse habitat and increasing population numbers. As part of the vegetation map, another objective for the CDC was to catalog the plant communities and their ecological condition in this special management area. Our other project objectives were to map and evaluate populations of squawapple (Peraphyllum romosissimum), a BLM Sensitive plant species known to occur within the HMP Area, and to assess the conservation status of the Buclswheat Flats Research Natural Area (RNA). Inaplementation of the HMP is also meant to benefit sensitive species such as squawapple, and add a measure of protection to the portion of the Buckwheat Flats RNA within the HMP Area boundaries (Bureau of Land Managemeat 1994).

\section{Locrtion}

The HMP Aree is located in west-central Idaho, approximately 15 miles north of Weiser, in Washington County (Figures 1 and 2). It encompasses approximately 27,740 acres, of which 19,730 are administered by the BLM and 8,010 are privately owned. The Payette National Forest borders the HMP Area to the north and northwest along the scuthern flanis of the Hit Mountains. Private lands border the southwestern, southern and eastern boundary lines. State Highway 95 passes within one mile of the HMP Area's southem boundary. The Mann Creek road provides the only direct public access into the HMP Area.

Physical setting

The HMP Area is characterized by rolling broken terrain dissected by several minor to larger-sized drainages. Steep areas are associated with slopes descending the brosd ridges to the draing bottoms. Mann, Sage, and Keithly creeks are the main stream systems, and generally flow in a north to south 


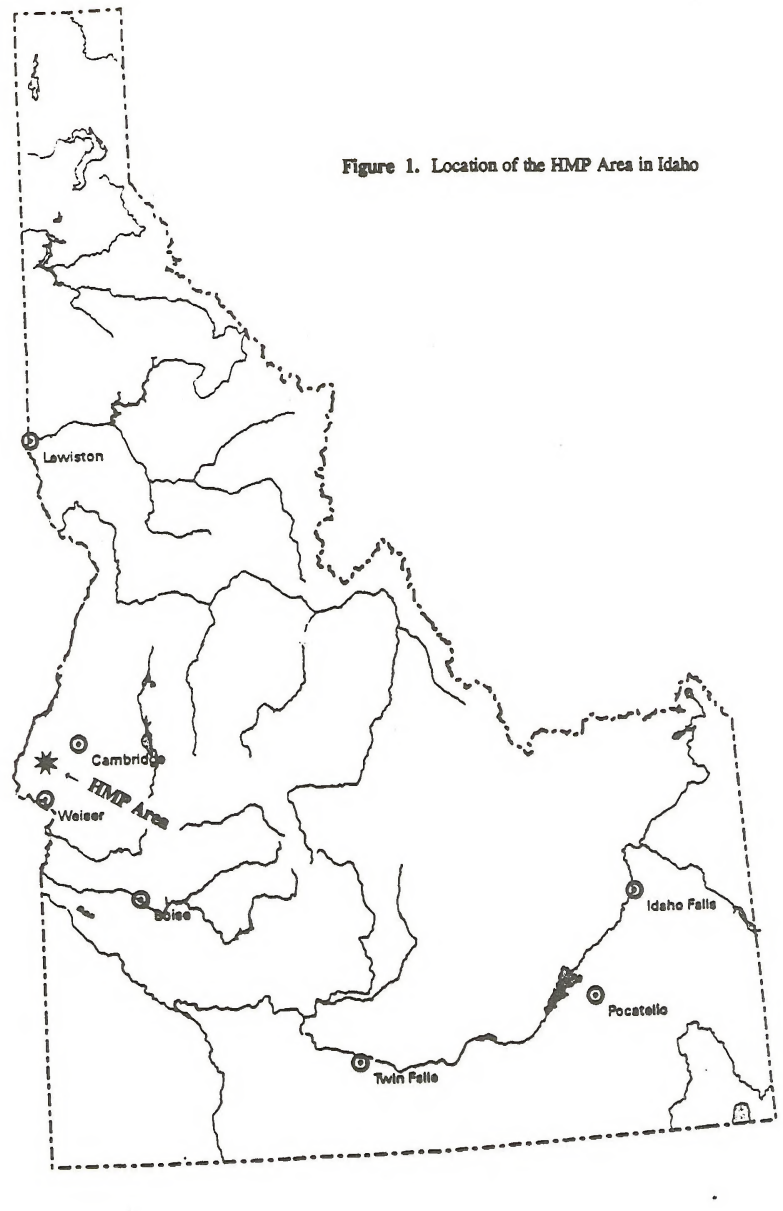




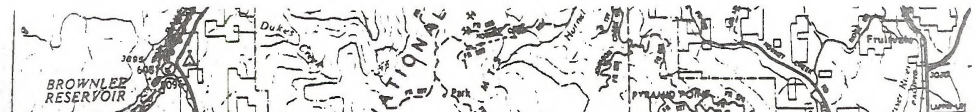
(7i) (2)

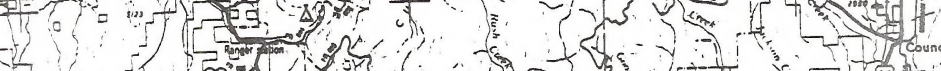

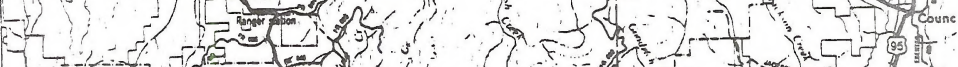

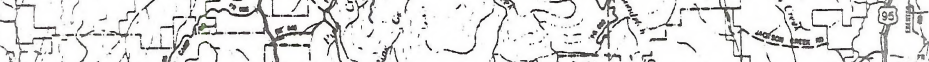

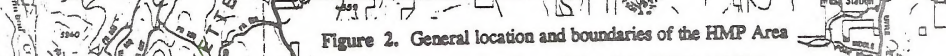

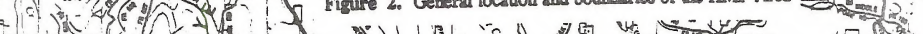

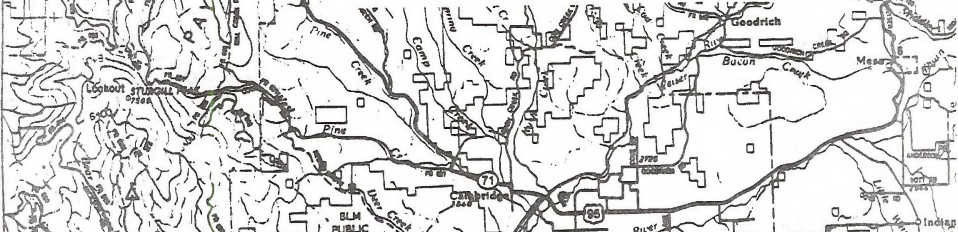

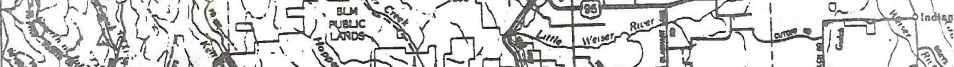
(2) 150 (1) inc

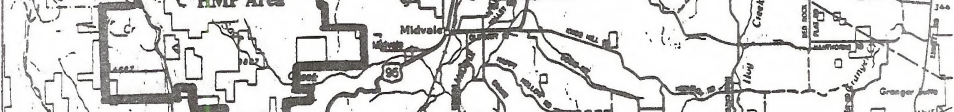

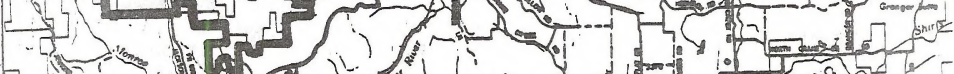

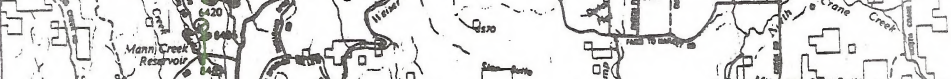

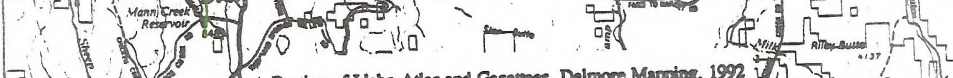

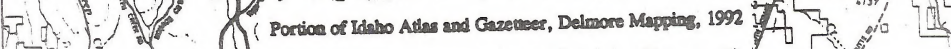

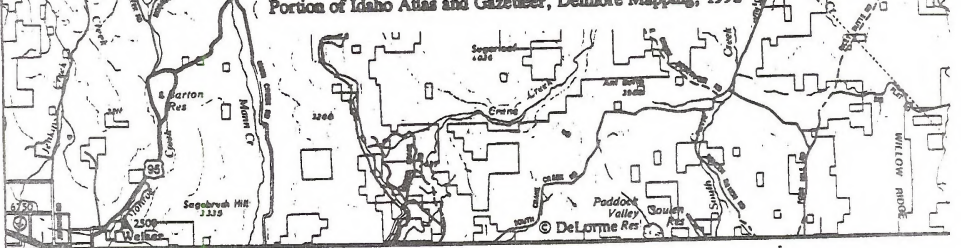


direction through the HMP Area. The uplands also trend north to south, but a diversity of aspects are provided by the many knolls and intersecting spur ridges. Elevations range from approximately 5,400 feet in upper Sage Creek to 3,100 feet along Mann Creek.

The HMP Ares is located within Bailey's Blue Mountain section (M332G) of the Middle Rocky Mountain Steppe - Coniferous Forest - Alpine Mesdow Province described by McNab and Avers (1994). Using other classifications, the HMP Area is located within the Wallowa-Seven Devils Section of the Columbia Intermontane Province (Ross and Savage 1967), and Blue Mountain Ecoregion (Omernik and Gallant 1986). It is part of the Columbia Division - Weiser Unit of the Idaho Floristic Region classification (Ertter and Moseley 1992).

\section{Geology}

The HMP Area is underlain by the Miocene-aged Columbia River Basait Group flows. It is located within a geologic area known as the Weiser embayment, the southenstern most extension of the Columbia Plateau. Following vulcanism, pronounced structural activity occurred throughout the embayment. The Weiser Basalt units in the Mann Creek ares were uplifted as the Surgill Peak block and anticline continued to rise. The area has a northeastern alignment, paralleling the Snake River fault system (Fitzgerald 1982). There are inclusions of arkosic sandstone and fine-grained volcanoclastic rocks within the HMP Area, mainly along the steep slopes above Mann Creek (Mitchell and Bennett 1979).

\section{Soils}

Most soils in the HMP Ares formed in a thin loess mantle over basalt residurum. Development of some of the deeper soils also includes colluvial material. Most are classified as Argixerolls. Gem-ReywatBakeoven, and Rigging-Meland soil unit groups dominate the HMP Area uplands. These main soil units vary from very shallow to moderately deep, and gently to steeply sloping. All are well-drained. Soil profiles are stony, at least in the upper layers, and loams are the main textural class. Clay accumulations are typical for these soils. Other soil units such as Klicker, DeMasters, Deshler, Midvale, Haw, and Gross are less abundant and widely distributed. Alluvial soils of the stream botioms show litule profile development and are derived mainly from the dominam basalt rock (Soil Conservation Service 1992).

We compared our vegetation map with the Soil Conservation Service's (1992) soil survey map for the HMP Area and found several consistent relationships. Xeric sagebrush (Antemisia tridensata sep. xericensis) communities are nearly exclusively associsted with Gem-Reywat, Riggins, Meland-Riggins, and to a lesser extent Gem and Groes soil units, while low sagebrush (Artemisia aribuscula) commonly occurs within the clayey Gem soil units. Scabland vegetation occurs in the shallow Bakeoven and Riggins, and to a lesser extent Gem-Reywat soil units. Canyon grasslands are associated with the Riggins soil unic Large mountain shrubfield communities are primarily associated with Meland-Riggins and Klicker soil units, and Doughas-fir (Psendotsuga mentiesin) stands with Klicker, DeMasters, and Meland soil units (Soil Conservation Service 1992).

\section{Climate}

From late fall to early spring, the climate of west-central Idaho is typically influenced by cool and moist Pacific maritime air. Periodically, this westerly flow is intermpted by outbreaks of cold, dry, continental air from the north. During the summer and early fall months, a Pacific high pressure system dominates 
weather patterns, resulting in minimal precipitation and more continental climatic conditions overall (Ross and Savage 1967). Weather data from Weiser, about 15 miles to the south, reflects general climate trends for the HMP Area. At Weiser, $49 \%$ of the average 12.4 inches $(316 \mathrm{~mm})$ of annual precipitation falls during the November through January winter months. Most of this would be snow in the HMP Area. There is another spike of increased precipitation during May and June before the dry summer begins, when only $14 \%$ of the average annual precipitation falls from July through October. The average anmual temperature at Weiser is $54.2^{\circ} \mathrm{F}\left(11^{\circ} \mathrm{C}\right)$, with December being the coldest and July the warmest months of the year (Johnson 1981). Because it averages over 1000 feet higher elevation, average temperatures are lower and precipitation higher within the HMP Area compared to Weiser.

\section{Vegetation}

The vegetation of the HMP Area is comprised of a mosaic of sagebrush, scabland, mountain shrubfield, grassland, conifer, and riparian plant communities. This mosaic largely parallels differences in aspect, soil type, and disturbance patterns. Sagebrush-steppe vegetation covers a majority of the rolling uplands. Xeric sagebrush (Artemisia tridentata ssp. xericensis) is the main tall sagebrugh species, with antelope bitterbrush (Purshia tridentata) being a prominent associate in most places. Grassland vegetation is most extensive where fire has lilled the sagebrush and antelope bitterbrush. Climax grasslands occur on dry, rocky, steep slopes in the major drainage canyons. Bluebunch wheatgrass (Agropyron spicarum) is the main bunchgrass in all late seral condition sagebrush and grassland habitats. Interestingly, Idabo fescue (Festuca idahoensis) is uncommon, being limited to a few north-facing slopes. Bulbous bluegrass (Poa bulbosa) is the primary invasive grass throughout the HMP Ares. It is an introduced perennial species that dominates all early seral vegetation, and is well established in many mid-seral stands as well.

Many ridgecrests and other rocly, shallow soil sites support a sparse, low-growing vegetation. High rock cover characterizes all of these scabland areas. Rock bucikwheat (Eriogorum sphaerocepholum) is the most common of the several scabland community types. They comprise the second most common vegetation class within the HMMP Area. Sandberg's bluegrass (Poe secunda) and/or bulbous bluegrass are the main scabland grasses. Areas with very clayey soils occur along many of the bottomlands and often support low sagebrush (Artemisia arbuscula) communities. Inclusions of low sagebrush occur in upland areas, but are much less common than scabland vegetation. The preliminary vegetation cover type map outlined in the HMP (Bureau of Land Management 1994) appears to grossly overestimate the amount of low sagebrush, especially in the northern and western portions of the HMP Ares.

Deciduous mountain shrub communities are interspersed throughout the HMP Area and support a diverse suite of tall to low shrubs. They are best developed in draws, slope concavicies, and along the brows of many northerly- and easterly-facing slopes. The rose family (Rosaceae) is well represemted, with bittercherry (Prunus emarginata) or cholkecherry (Prunus virginiana) being common community dominants. Douglas-fir (Pseudotuge menziesil) stands occur on mesic aspects at the higher elevations, but are more extensive on adjacent Forest Service lands. Narrow bands of black hawthorne (Crascegus douglasii)- or mountain alder (Alnus incana)-dominated riparian vegetation occur along most watercourses. A small portion of the HMP Area has been seeded to intermediate wheatgress (Agropyron ituermedium).

We identified 24 plant community types within the HMP Area (Table 1). Twenty of the types are based on descriptions in various published classifications, while four are not yet part of any regional classification. The bulbous bluegrass type is the only one that is clearly an anthropogenic type. It occurs as a very 
Table 1. Plant community types occurring within the HMP Area.

\section{Name}

${ }^{1} \mathrm{Ref}$.

Sageboush shrubland

1. Xeric sagebrush/bluebunch wheatgrass

(Artemisia tridentasa ssp. xericensis/Agropyron spicanum)

2. Xeric sagebrush/Idaho fescue

(Artemisia tridentate ssp. rericensis/Festuca idahoensis)

3. Basin big sagebrush/basin wildrye

(Artemisia tridentata var. tridentata/Elymus cinereus)

4. Low sagebrush/Sandberg's bluegrass

(Arremisia arbuscula/Poa secunda)

5. Low sagebrush/bluebunch wheatgrass

(Artemisia arbuscula/Agropyron spicatum)

6. Low sagebrush/Idaho fescue

(Artemisia arbuscula/F estuca idahoensis)

7. Antelope bitterbrusb/bluebunch wheatgrass

(Purshia tridentasa/Agropyron spicatum)

Grassland

8. Bluebunch wheatgrass-Sandberg's bluegrass/arrowleaf balsamroot

(Agropyron spicaum-Poa secunda/Balsamorhiza saginato)

9. Idaho fescue-bluebunch wheatgrass

1

10. Bulbous bluegrass

(Poa bulbasa)

\section{Scabland}

11. Rock buckwheat/Sandberg's bluegrass (Eriogonum sphoerocephalum/Poc secunda)

12. Thyme-leaved buckwheat/Sandberg's bluegrass (Eriogonum thymoides/Poa secunda)

13. Stiff sagebrush/Sandberg's bluegrass (Artemisia rigida/Poa secunda)

14. Gray's biscuitroot/Sandberg's bluegrass (Lomasium grayi/Pos securda)

Mountain shrubland

15. Mountain shrub

16. Talus-shrub garland

17. Mallow ninebark

(Physocarpus mabraceus)

Conifer forest

18. Douglas-fir/common mowberry (Pseudotsuga menziesti/Symphoricarpas albuss)

19. Douglas-fir/mallow ninebark (Pseudotsuga menziesil/Physocarpus mahaceus)

20. Douglas-fir/pinegrass

(Pseudotsuga menriesil/Calamagrastis rubescens)
1

1

1

1

1

1

2

2

none

3

3

2

none

none

4

4

5

5

5 
(Table 1. continued)

Name

${ }^{1} \mathrm{Ref}$

21. Grand fir/white spirea

5

(Abies grandis/Spiraea berulifolia)

Biparian

22. Black hawthorne

(Crataegus douglasii)

23. Mountain alder/water birch

none

(Alnus incona/Berula occidentalis)

24. White alder/syringa

(Ainus thombifolia/Philadelphus lewisiz)

${ }^{1}$ References (Ref.) used to classify the vegetation are: 1 = Hironalca et al. (1983); 2 = Tisclale (1986); 3 = Daubenmire (1970); 4 = Johnson and Simon 1987; 5 = Steele et al. 1981; 6 = Miller (1976).

early/early seral condition community in degraded xeric sagebrush, antelope bitterbrush, and bluebunch wheatgrass habitat types. The cover type names used for the vegetation map are more inclusive and often encompess more than one community type. Plant nomenclaure follows Hitchcock and Cronquist (1973) for most species.

There was a pronounced difference in the ecological condition of the unburned vegetation located within the "Hixon Preserve Field" exclosure versus adjacent areas open to livestock grazing. Plant communities within the exclosure were commonly more diverse and in a more advanced seral stage. In 1989 , over $30 \%$ of the HMP Area was burned by wildifre (Bureau of Land Mamaement 1994), mostly in the Sage Creek drainage. The fire eliminated large areas of sagebrush and antelope bitnerbrush coverage. Overall, we saw little regeneration of these shrubs during our 1996 survey work. Bluebunch wheatgrass is common in places, but in most burned aress, the present grassland vegetation is dominated by bulbous bluegrass and annual bromes.

Noxious weeds are not that well established within the MMP Area yet. A few small, scattered populations of leafy spurge (Euphorbia esula) were observed and have been mapped (Appendix 1). This species is rapidly expanding its range in Washington County, and prompt control, including periodic inventories, will be important to prevent further establishment within the HMP Area. Hoary whitetop (Cardaria draba) is more widespread, but seems to be concentrated around the Fairchild Reservoir and associated ditchway areas. Scotch thistle (Onopordum acanthium) or other thistle species (Cirsium spp.) are locally common in several disturbed areas. We did not observe any knapweed (Censourea species) populations. However, most disurbed aress prone $n$ lonpweed invasion were visited eariy in the season, prior to the time species in this group flower.

\section{VEGETATION MAP FOR THE HIXON COLUMBIAN SHARP-TAILED GROUSE HABTTAT MANA GEMENT PLAN AREA}

\section{Methods}

The vegetation map for the HMP Area is based on the field imventory method. Surveys were conducted by 
hiling through as much of the HMP Area as possible. Access was gained using the Mann Creek, East Fork Deer Creek, Fairchild Reservior/Sage Creek, and Keithly Creek rosd networks. Field work wes conducted between May 21 - June 10 and August 12 - 13, 199\%. The boundaries of a particular vegetation unit were delineated in the field onto a clear acetate overlay taped to the appropriate $1: 24,000$ scale color aerial photograph. The aerial photographs used for this project were taken for the BLM on July 31,1987 , under identification code $\mathrm{DD}-87 \mathrm{BC}$. Photos 6-7-11 to 13, 6-8-20 to 25, 6-9-20 to 24, and 6-10-21 to 24 provide stereoscopic coverage for most of the HMP Ares. Vegetation and other notes necessary for classification were recorded into our field notebooks. These notebooks are on file at the CDC office in Boise.

After completing our field work, polygons delineated on aerial photos were refined and transferred to 1:24,000 orthophoto maps. These were then traced onto 1:24,000 U.S.G.S. topographic quadrangles and provide the template for GIS digitization. The vegetation map comprises portions of four 7.5' U.S.G.S. topogrpahic quadrangles - Hopper Creek, Mann Creek NW, Midvale Hill, and Surgill Peak. The vegetation map exists in two formats. One is a color-and numerically-coded GIS generated map, and the other consists of numerically-coded polygons drawn onto the four U.S.G.S. topographic quadrangles covering the HMP area. The scale of both formats is $1: 24,000$.

The vegetmion map classification is based on existing cover types reflectiog a site's actual vegetation. We used floristic, structural, and to a lesser exteat wildlife habitat criteria to devise the cover type classification. Cover type circumscription is besed on published clascifications as much as poseible (see Table 1). Each polygon (vegetstion mapping unit) on the map has been assigned a primary cover type. Polygon boundries were delineated largely on the basis of vegetation pattern bomogeneity, although large homogenous blocles of vegetation are uncommon dve to frequent changes in topography and soils. Because of this, the majority of polygors are comprised of more than one cover type. The typical pattern is to have a polygon dominated by one cover type, but containing one or more other cover type inclusions. These inclusions are noted in the polygon descriptions and in Appendix 2. Because of their importance as sharptailed grouse habitat, inclusioss of the mountain shrub and black bawthome cover types are depicted on the vegetation map as well as being noted in the polygon description. A designated symbol (0) shows the occurrence of mountain shrub and black hawthorne inclusions on the hard copies of the regetation map.

Cover types are described from field arveys, supplemented by a limited amoun of selective vegetation sampling. In addition, the ecological condition of many sagebrush, grassland, and scabland communities was assessed during field surveys. This information is noted in the polygon descriptions section and in Appendix 2.

\section{Vegetation map cover type descriptions}

The HMP Area vegetation map consiats of 13 cover types grouped into six habitat classes - sagebrush, grassland, scabland, mountain shrub, conifer forest, and riperian (Table 2). Bach cover type has a six letter code used in the polygon descriptions. The codes are derived from the scientific name of the cover type's dominam species. Aquatic babitats such as reservoirs and stock ponds are not considered in this classification.

\section{Sagebrush cover types}

Xeric sqgebrush (Antemisin wdemena sp, rericensir: ARTURX). The presence of xeric sagebrush with a 
Table 2. Cover types for the HMP Area vegetation map.

\begin{tabular}{|c|c|}
\hline Name & Code \\
\hline \multicolumn{2}{|l|}{ Sagebrush } \\
\hline $\begin{array}{l}\text { 1. Xeric sagebrush cover type } \\
\text { (Antemisia tridentase ssp. xericensis) }\end{array}$ & ARTTRX \\
\hline $\begin{array}{l}\text { 2. Low sagebrush cover type } \\
\text { (Artemisia arbuscula) }\end{array}$ & ARTARB \\
\hline \multicolumn{2}{|l|}{ Grassiand } \\
\hline $\begin{array}{l}\text { 3. Bluebunch wheatgrass cover type } \\
\text { (Agropyron spicatum) }\end{array}$ & AGRSPI \\
\hline $\begin{array}{l}\text { 4. Bulbous bluegrass cover type } \\
\text { (Poc bulbosa) }\end{array}$ & POABUL \\
\hline $\begin{array}{l}\text { 5. Intermediate wheat cover type } \\
\text { (Agropyron intermedium) }\end{array}$ & AGRINT \\
\hline \multicolumn{2}{|l|}{ Scabland. } \\
\hline $\begin{array}{l}\text { 6. Rock sagebrush cover type } \\
\text { (Eriogorum sphoerocephalum) }\end{array}$ & ERISPH \\
\hline $\begin{array}{l}\text { 7. Thyme-leaved buclwheat cover type } \\
\text { (Eriogonum thymoides) }\end{array}$ & ERTTHY \\
\hline $\begin{array}{l}\text { 8. Gray's lomatum cover type } \\
\text { (Lomatium groyl) }\end{array}$ & LOMGRA \\
\hline \multicolumn{2}{|l|}{ Mountain shoub } \\
\hline $\begin{array}{l}\text { 9. Mounmin sbrub cover type } \\
\text { Conifer fores }\end{array}$ & MTSHRUB \\
\hline $\begin{array}{l}\text { 10. Douglas-fir cover type } \\
\text { (Pseudotsuga menziesti) }\end{array}$ & PSEMEN \\
\hline \multicolumn{2}{|l|}{ Ripacian } \\
\hline $\begin{array}{l}\text { 11. Black hawhorne cover type } \\
\text { (Crataegus douglasit) }\end{array}$ & CRADOU \\
\hline $\begin{array}{l}\text { 12. Mountain alder cover type } \\
\text { (Abus incona) }\end{array}$ & ALNINC \\
\hline $\begin{array}{l}\text { 13. White alder cover type } \\
\text { (Alnus mombifolia) }\end{array}$ & ALNRHO \\
\hline
\end{tabular}

graminoid-dominated understory distinguishes this cover type. Antelope bitterbrush is often prominent and in some cases equals or surpases the covernge of reric sagebrush. In older stands that heve escaped recent fires, the antelope bitterbrush is often taller than the reric sagebrush. Canopy cover of the two shrubs varies from greater then $50 \%$ to less than $10 \%$, and is commonly in the $10 \%-20 \%$ range. Dense stands tend to be local and scattered within the more open areas. The only other upright shrub that commonly occurs within this community is gray rabbitbrush (Chrysothamous nouseasus).

Bluebunch whentgrass is the primary bunchgrass is late and mid-seral communities. Squirreltail (Sitanion hystrix) can be common in places and is likely indicative of a more mid-seral condition. Bulbous bluegrass dominates large areas with an early seral understory. It is also abundant in many mid-seral communities. 
Other introduced grasses such as the annual bromes (Bromus spp.) can also be common in all but late seral communities. Most polygons contain a mosaic of successional stages that probably parallel the livestock grazing and fire history of the area. Idaho fescue does not occur in this cover type except locally on a few north-facing slopes. Native forb diversity is greater in mid- and late-seral communities. Forbs such as balsamroot (Balsamorhiza segittasa), spurred lupine (Lupinus laxifionus), and common yarrow (Achilleo millefolium) are usually present even in disturbed areas.

Xeric sagebrush is the most common cover type in the HMP Area. It is also a common inclusion within the other map cover types, especially on deeper soils pockets within the various scabland types, and as the matrix between tall shrub patches characterizing many mountain shrub communities. Nearly all of this cover type is representative of the Arremisia tridentata ssp. xericensis/Agropyron spicarum (Artux/Agrspi) habitat type (Hironaka et al. 1983). Polygons with the ARTTRX cover are this habitat type unless noted otherwise in the polygon description. The Artemisia tridentasa ssp. xericensis/F esusca idahoensis (Artur/Fesida) habitat type (Hironalo et al. 1983) is uncommon, found only along northerly slopes above Sage Creek in the eastern portion of the HIMP Area. Areas where most of all of the reric sagebrush and antelope bitrerbrush has been killed by fire are mapped as one of the grassland cover types. The xeric sagebrush cover type encompasses the few antelope bitwerbrush communities that occur within the HMP Area. These communities are related to the Purshie tridentata/Agropyron spicarun (Purti/Agrspi) habitat type described by Hironaka et al. (1983). Patches of basin big sagebrush (Anemisia sridentata ssp. iridentara) occur along some terraced bottomlands that are also part of the reric sagebrush cover type. These areas are likely related to the Artemisia sridentara ssp. tridentatalEhymus cinereus babitat type (Hironaka et al. 1983), but are 20 disurbed it is difficult to tell for sure. Additional general information concerning ssp. rericensis can be found in Rosentreter and Kelsey (1991) and Wimward and Tisdale (1977). Xeric sagebrush vegetation was sampled at three sites, and the date summarized (Appeadix 3).

Low sagebrush (Artemisia ambusmia: ARTARB) - This cover type is fairly widespread within the FMP Area, but only a few larger sites in the Faircbild Reservoir ares are mapped sepantely. Low sagebrush communities are best developed on very clayey solis that are ephemerally saturated in the spring due to poor drainage properties. The high-clay soils tend to be have a light surface cover and in most cases can be distinguished on aerial phoms. The larger low sagebrush communities are associated with drainage botom areas, with small inclusions occurring in upland zeric sagebrush or scabland cover types. Low sagebrush clearly dominates this cover type, with coverage varying between $10 \%$ and $35 \%$ in most places. Lowgrowing antelope bitterbrush may be present in low density. Bluebunch wheatgrass is the most abundant graminoid in most late seral stands. In earlier seral communities it decreases significantly, while bulbous bluegrass and squirreltail increase. Associnted forb cover is low, although diversity can be relstively high, including several species otherwise uncommon in the HMP Ares. Bare ground coverage is usually at least $50 \%$.

Most low sagebrush communitied within the HMP Ares are the Artemisio arbuscula/Agropyron spicanum (Artarb/Agrspi) habitat type (Hiromala et al. 1983). Two other low sagebrush hobitat types described by Hironaka et al. (1983) occur in minor amounts, Artemisile arbuscula/Pon secuonde (Artarb/Poasec) and Artemisia arbuscula/s esmica idahoensis (Artarb/Ferids). Antemisia arbuscula/Poa securia occurs on sites with soils wo shallow is support blvebunch whestgress, while Artemisia arbuscula/F erruca idahoensis is differentiated by the presence of Idaho fescue. Both are noted as inclusions in a couple of polygons. Low sagebrush vegetation was sampled at three sites, and the datn summarized (Appendir 3). 


\section{Grassland cover types}

The HMP Area is located in a region where the lowlands are dominated by sagebrush-steppe vegetation. As a result, climax grassland vegetation is relatively uncommon compared to the Hells Camyon area further north. Most polygons mapped as the xeric sagebrush cover type contain naturally open areas with widely scattered shrubs. For purposes of the vegetation map, these open, buachgrass-dominated grassland areas are considered part of the xeric sagebrush cover type mosaic, and not mapped separately as grasslands.

Bluebunch wheatorass (Agropyron spicanm: AGRSPD - This cover type includes two types of vegetation: (1) climar grasslands that never supported shrubs and related to the caryon grassland vegetrtion typifying Hells Canyon to the sorth, and (2) grasaland vegetation in burned sagebrush communities that are climax Arttry/Agrspi. Grassland vegetation containing bluebunch wheatgrass characterizes this cover type in both cases. Climax grasslands are found on northeasterly and westerly slopes within the Buckwheat Flats RNA, east- and west-facing slopes above the Mann Creek road and in upper Sage and Keithly creels, xeric slopes above Fir Creek, and the south-facing slope above lower Adames Creek. All of these areas are sioep and rocky. The soils above the Mann Creek roed are not derived from Columbia River Basalt rocks like the rest of the HMP Area, but from sedimentary and fine-grained volcaniclastic parent material (Mitchell and Bennet 1979). These grasslands are related to the Agropyron spicanum-Pos secunda/Balsamomizo sagirtasa (Agrspi-Poasec/Balsag) habitat type described by Tisdale (1980). The Bucikwheat Flats RNA area also supports a minor amoumt of the Fesauca idahoensis-Agropyron spicatum (Fesida-Agrspi) habitat type (Tisdale 19:6).

This cover type is more common in burned reric sagebrush/bluebunch whestgrass sites, where little or no shrub regeneration has taken place. Herbaceous composition is similne to the reric sagebrush cover type. Bluebunch wheatgrass and native forbs dominate late seral berbacecus layers. Bulbous bluegrass and/or squirreltail may be co-dominsan, or even dominste mid-seral conditions. Early seral grassland vegetation strongly dominated by bulbous bluegrass is mapped as the bulbous bluegrass cover type.

Bulbous bluegrass (Pan bulbosa. POABUIL) - This is a very early or early seral condition cover type with the vegetation dominated by bulbous bluegrass. Annual brome species are usually common and bluebunch wheatgrass rare or comfioed to scattered clusters. Associated native forbs tend to be "increasers" such as hawksbeard (Crepis spp.), spurred lupine, and autumn willowweed (Epilobium panicularum). Introduced weedy forbs include salsify (Tragopogon dubius) and thistles (Cirsiun spp.). This cover type occurs in areas where the native bunchgrasses were likely depleted prior to fires that killed off the xeric sagebrush and antelope bitterbrush. In places, burned shrub skeletons or only the charred bases may remain. The habitit type for these sites is predominntely Artemisia tridenuata ssp. xericensis/Agropyron spicanum, but also includes Artemisla arbuscula/Agropyron spicarum, Purhia tridentata/Agropyron spicanum and Agropyron spicanm-Poc secunda/Balsamorhize sagincua These early seral grasslands often occur in areas of gentle topography that were, and still may be used heavily by livestock.

Intermediate when (Arnowuron intermedium: AGRINDO - This cover type applies to areas that have been successfully seeded to intermodiate wheat monocultures. The nadive vegention, including the shrubs are basically gone, although some regeneration may be occurring. It does not include aress where intermediate wheat has just been interseeded and components of the native vegetation persist. The vegetation is considered a very early seral version of the Anemisia midensata ssp. xericensis/Agropyron spicanun habitat type. This cover type is confined to one polygon in the southeastern portion of the HMP Area, east of Deer 
Creek.

\section{Scabland cover types}

Scabland refers to sites where soils are stony and very shallow to bedrock, and supporting a sparse, lowgrowing vegetation. Most sites are flat to gently sloping. Further west, in Oregon and Washington, a well developed cryptogamic crust is usually associated with scabland sites. This is not the case in Idaho, where crust development is minimal and bare ground/gravel-small pebble/rock coverage usually high. However, many of the rocks and larger pebbles jutting above the surface may be covered with lichens and to a lesser degree mosses. Scabland vegetation contains a characteristic low-shrub dominant, Sandberg's bluegrass as the main native bunchgrass, and a suite of distinctive low forbs, most of them absent in nearby deeper soil habitats. Daubenmire (1970) suggests that variation in the fracture network of the underlying basalt may be a key factor in determining the variation in scabland shrub dominants. Livestock may trail through, but probably do not spend much time foraging in the scablands. Seral pathways bave not been well-studied for most scabland vegetation. Most comrnunities within the HMP Area appear to be largely mid-seral, with bulbous bluegrass at least as common as Sandberg's bluegrass. Iate seral examples contain relatively litule bulbous bluegrass, while an early seral herbaceous byer has few native bunchgrasses. The scabland communities are relatively resistant to fire, and unburned inclusions are commoniy surrounded by burned xeric sagebrush babitats.

For purposes of the vegetation map we recognize three scabland cover types. A fourth scabland community type, stiff sagebrush/Sandberg's bluegrass (Antemisia rigida/Poa secunda; Artrig/Poasec) occurs within the HMP Area, but strnds are of insufficient size to warrant a separate cover type. It is restricted to a few inclusions in the eastern half of the HMP Area. The presence of stiff sagebrush instead of one of the low buckwheats chrracterizes this scabland community. Grass and forb associates appear to be similar to the other scabland types. Regional classifications by Daubenmire (1970), Rall (1973), Tisdale (1986), and Johnson and Simon (1987) describe strff sagebrush communities. Minor amouns of the Anemisia arbuscula/Poo secunda habitat type occur within the FIMP Ares, but we are recognizing it as part of the sagebrush cover type series even though it shares several characteristics with scabland vegetation.

Rock buck where (Erieganum spharocenhahum: ERISPED - Rock buckwheat is the dominast and in many cases the only low-growing shrub occurring in this cover type. Small amount of Eriogonum thymoides and/or $\boldsymbol{E}$. umbellatum may be imterspersed, often in a segregated maner. A low, sprawling form of antelope bitterbrush ocessionelly occurs along the scabland firinges. Toul shrub cover is under $20 \%$ in most if not all places. Sandherg's bluegrass is the primary native bunchgrass in late seral stands. The presence of this grass and the abeence of bluebunch wheatgrass belp detine this cover type. Bulbous bluegrass is the main invasve grase and the dominant graminoid in at least portione of many polygons. Many examples of this cover type have more bulbous bluegrass than Sandberg's bluegrass, but otherwise look undisturbed. It appears likely that bulbous bluegrass will remain a part of these scabland communities indefinitely. Forb covernge is low, with Lomothum spp. (biscuitroots), Altum spp. (onions), Microseris troximoides (falss-agoveris), and Trifolin macrocephahum (big-head clover) being common associstes. The tandem of buckwheats and associnted forbs can provide a colorful wildflower display in the spring.

This is the most common scabland cover type within the HMP Ares. The other scablard communities occur as inclusions within this main type. This cover type is related to the Eriogonum sphaerocephabum/Poa secunda habiat type described by Daubenmire (1970), although it differs in several 
ways - (1) the presence of bulbous bluegrass; (2) Sandberg's bluegrass coverage tends to be lower (even counting the cover of bulbous bluegrass); (3) somewhat lower associated forb diversity; and (4) the association of different species of Lomatium, and the absence of Haplopappus stenophylus. We conducted ecological sampling at three locations, and the dat have been summarized (Appendix 3).

Thyme-leaved buchatheat (EDiogonum thumoides: ERITHOO - This is the most depauperate of the scabland cover types. Thyme-leaved buckwheat plants are well-spaced, occurring at less than $10 \%$ cover. Other buckwheats are rare or absent, with Sandberg's bluegrass being the main native bunchgrass. Bulbous bluegrass is the principle invasive grass, but it does not establish very well within this cover type. Grass cover is also usually less than $10 \%$. Forbs may be abundant in number, but because individuals are small and fine-leaved, their cover is minimal. Large expressions of this cover type are sare, and more often it occurs as an inclusion within the rock buclwheat type. Because of this pattern, the vegetation map does not contain polygons with only the thyme-leaved buckwheat cover type.

This cover type differs from the Eriogonum thymoides/Poa secunda babitat type described by Daubenmire (1970) in similar ways as the rock buclswheat cover type. We sarupled three sites and the dat have been summarized (Appendix 3).

Gray's hiscuitroot (Lomarinm grayi. LOMGRA) - This scabland cover type is distinguished by the dominance of Gray's biscuitroot, with Sandberg's bluegrass being the main native bunchgrass. Bucliwheats or other shrubs are rare or absem. Bluebunch wheatgrass and squirreltnil are occasionally represented at low density. Bulbous bluegrass has invaded most sites to one degree or another. Associated forb diversity and abundance appears similar to the other scabland communities. This minor cover type is usually part of a larger rocis buckwheat-dominated scabland complex, or an inclusion within the reric sagebrush or grassland cover types. It has not been described in any regional classifications. We sampled one site within the Buclowheat Flats RNA and have summarized the data (Appendix 3). A variation of this cover type was observed on steep, very rocky, sparsely vegetated slopes that contained a profusion of hot-rock penstemon (Penstemon deusnus) and scattered clumps of bluebunch wheatgrass.

\section{Mountain shrub cover type}

Mountain shrub comrunities are widespread within the HMP Ares. They are best developed on steep easterly exposures, especially along upper slope and brow positions. Mountain shrubfields are common along northern aspects at the lower elevations, but tend to be replaced by Douglas-fir stands above approximately 3,600 feet in the Fir and Keithly creels areas. Draws, slopes adjacent to riparian areas, topographic concavities, and ridgetops with deeper, better drained soils are other areas that often support mountain shrub vegetation. Many shrubtields are long and narrow in shape. Shrub cover is variable and can be discontiruous in places, bur overall is usually at least $50 \%$. Shrubfields characterized by a patchy shrub distribution are usually interspersed within a reric sagebrush/bluebunch wheatgrass community matrix. Marry shrubfields have burned in recent fires that have swept through parts of the HMP Area. In most places we observed good shrub regeneration. This is primarily an upland vegetation, but it occasionally occurs in riparian habitats.

Mountain shrub MTSURUR) - Vegetation dominated by a diverse list of deciduous shrub species distinguishes this cover type. Common shrubfield species include bittercherry, cholecherry, serviceberry (Amelanchier alnifolia), raallow ninebark, Wood's rose (Rasa woodsib), black hawhorne, antelope bitterbrush, Rocly Mountain maple (Acer glabrum), common snowiberry (Symphoricarpos albus), 
mountain snowberry (Symphoricarpos oreophilus), snowbrush ceanothus (Ceanothus velutinus), Oregon creeping grape (Berberis repens), and big sagebrush (apparently both Arremisia tridensosa ssp. vascyana and ssp. xericensis). Many shrubfields are dominated by one species, most commonly bittercherry. Less often chokecherry is the community dominant. In the Keithly Creek drainage, several shrubfields are dominated by mallow ninebark. Snowbrush ceanothus or antelope bitterbrush are the most abundant shrubs in a few siujations. Polygon descriptions will note when a particular species is known to be the community dominant. There are also many mountain shrub communities where there is no clear dominant. The composition and ratio of shrub species comprising these mired shrubfields is variable. Shrubfield structure ranges from a single uniform height, to more complex multiple layer communities. Thickets generated from many root sprouts is a distinguishing character of many bittercberry-and chokecherry-dominated communities.

Some mountain shrubfields at upper elevations within the HMP Area contain scattered individual or small clusters of Douglas-fir trees, while other areas that bave recently burned contain snags and/or young regeneration. These seral shrubtield comnunities occur in the Keithly Creek, Fir Crcek, and upper Sage Creek areas. Bittercherry is the most abundamt shrub in nearly all cases. Steele and Geier-Hayes (1989) recognize bittercherry as one of the mid-seral shrub layer successions within the Douglas-fir/mallow ninebark habitat type. They also recognize snowbrush ceanothus and Scovier's willow (Salbr scouleriana) layer groups for this babitat tyge, both of which appear to be present within the EMMP Area.

The mounaio shrub cover type includes talus-shrub gariands, which are inclusions of large to small nlus streams ringed by a deciducus shrubs. The garlands are positioned on steep slopes downslope from eroding cliffs or rock outcrops. Common gariand species are syringn (Philadelphus lewisti), cholrecherry, elderberry (Sambucus cerulea), and serviceberry. Talus-shrub garlands are not as common within the HMIP Area as further north in Hells Canyon.

Montane mixed deciduous shrub communities are not described is any regional classification. Roberts (1971) investigated bittercherry on the Boise National Forest, but does not include a classification. Mancuso and Moseley (1995) provids some descriptive information for bittercherry communities in the Brownlee area. Mancuso (1995) briefly summarizes cholkecherry communities for the Ratrdennet creelas area north of the HMP Area. Mansgement, successional, and vegetntion informstion for \& number of seral shrub community groups are discussed in Steele and Geier-Hayes $(1989 ; 1993)$. Talus-shrub garland vegetation for the Hells Canyon area is described by Johnson and Simon (1987).

\section{Forest cover types}

The most extensive forest stands within the MMP Area are found on the slopes above Keithly Creek. Well developed stands also occur in the Fir Creel, and 10 a lesser degree upper Sage Crsek drainages. Large blocks of conifer forest are abundarat north of the HMP Area in the Hit Mountains on the Payette National Forest. Douglas-fir is the primary conifer species througbout the MMP Ares. Ponderose pine (Pinus ponderosa) are scattered within sorne forest stands, and grand fir (Abies grondis) occurs locally along Keitaly Creek.

Douglas-fie (Esendorsura menziasti. PSEMEEN) - Open to closed stands of Dougiss-fir readily distinguishes this cover type. Larger polygons ussully contain both open and closed canopy areas. The understory is dominated by deciduous shrub species in most places. Shrub density is highest where the canopy is more open. Common snowberry and mallow ninebark are the most common forest shrubs, although 
bittercherry, serviceberry, white spiraes (Spiraea betulifolia), and Rocicy Mountain maple can also be common. A fringe of shrubs often extends beyond the forest margin and grades into the adjacent sagebrush-bitterbrush vegetation. Areas where shrubs are more or less absent support a pinegrass (Calamagrostis nubescens) understory. There are also a few forested areas where intensive livestock and probably wildlife use as well, has resulted in an understory of mostly bare ground and/or weedy annuals. This was observed in areas adjacent to stock reservoirs and gente upper slopes, where a lot of trailing and bedding occurs. On the steep slopes above Keithly Creek, bands of grassland vegetation regularly interrupt the forest where the soils are rocly and shallow. These canyon grassland (Agropyron spicaum-Poo secunda/Bolsamorhiza sagirtata babitat type) inclusions are mapped as part of the forest vegetation.

Most forest polygons support the Pseudotsuge menziesii/Symphoricarpos albus (Psemen/Symaib) or Pseudotsuga menviesii/Physocarpus malvaceus (Psemen/Phymal) habicat types (Stsele et al. 1981). The Pseudotsuga menziesii/Calamagrostls rubescens (Psemen/Calrub) babitat type (Steele et al. 1981) is less widespread. Terraces along Keithly Creek near the northern boundary of the HMP Area support small amounts of the Abies grandis/Spiraea betultfolia (Abigra/Spibet) babitat type (Steele et al. 1981). They note that in some places common snowberry replaces white spiraea as the understory species. This is the case along Keitbly Creek. Several swali, outlying forest polygons contain a mixed deciduous shrub understory usually domioated by bittercherry. These areas apparently support the Pseudotsuge menziesii/Physocarpus malvaceus babitat type. Stands that have recently burned in the Keithly Creek and upper Sage Creek drainages are presently dominated by mountain shrub species.

\section{Riparian cover types}

Riparian vegetation within the FIMP Ares occurs as a narrow band alongside perennial and ephemeral watercourses, and usually has a sharp ecotone differentiating the adjacent uplands. Most riparian stretches are shrub-dominated. There are a few wet meadow habitats dominated by species such as common spikerush (Eleocharis palustris) or other graminoids. These are noted in the polygon descriptions, but no vegetation map cover types are described for riparian meadow vegetation.

Black hawhome (Crataegus douglasil: CRADOU) - This riparian cover type is distinguished by the dominance of black hawthorne, which often forms a nearly impenetrable thicket. The black bawthorne usually averages $3-5 \mathrm{~m}$ tall, and multiple size (age?) classes were observed in most places. Some riparian sections can have abundant Geyer's willow (Saltr geyeriana), or whiplach willow (Saltr lasiandra). Other deciduous shrubs such as Wood's rose, cholecherry, serviceberry, golden currant (Ribes aureunn), and common snowberry occur at low density. Along Deer Creek, red-osier dogwood (Comus stolonifera) was the main associated shrub. The herbaceous layer seems to usually have higher graminoid than forb coverage, and invariably couthins several introduced species such as Kenwicly bluegrass (Pos pratensis). The heavy livestock use associated with these riparian areas bas infuenced their composition and structure. Riparian vegetation domineted by black hawhorne has been reported from throughout the Pacific Northwest. In all instances, it is reported to be rare or uncommon due to impects of livestock grazing and agricularal activities (Groseman et al. 1994)

Marks and Marks (1987) noted their riparian (RIPA) cover type for the FMP Ares corresponded to Daubenmire's (1970) Crataegus douslasil//ieracleum lanown habitat type. Although they are similar in some regards, we feel neither of Daubenmire's (1970) C. douglasii habitat types (Crataegus douglasi//Symphoricarpos albus is the other one) are fully satisfactory. There are several other regional classifications that contain black hawthorne types. The C. douglasiliRase moodsil association outlined in 
Grossman et al. (1994) appears to be similar in most regards. Mancuso and Moseley (1995) outline a black hawthorne cover type for their Brownlee study area. Crowe and Clausnitzer (1995) describe a disturbanceinduced black hawthorne community type for the Wallowa Mountains that is similar except for the lack of willows. Kovalchik (1987) describes a black hawhorne riparian association for central Oregon, and Hansen et al. (1995) describe a grazing-induced C. succulenta (succulent bawhorne) community type for Montana that includes black hawthorne. Black hawthorne riparian communities within the BMP Area may also be disclimax, or disturbance induced, at least in some places. Many riparian segments dominated by black hawthorne contain sufficient water to support willow-dominsted communities. The occurrence of scattered short stretches with a lot of willow may indicate a remnant rather than subordinate status. We sampled three black hawthorne communities within the HMP Ares, and have summarized the data (Appendix 3).

Mountain alder (Alous incana: ALNTNC) - Keithly Creek and sections of Sage Creek support riparian vegetation dominated by a dense mountain alder overstory and diverse understory shrub layer that includes willow species (Salix spp.), syringa, Rocky Mountain maple, black hawthorne, Wood's rose, water birch (Betula occidenralis), common snowberry, red-osier dogwood, and golden currant. There may be intermittent gaps in the aider overstory, and for short stretches it may be replaced by water birch, willow species (e.g., Salix rigida), or black cottonwood (Populhs trichocarpa). Doughs-fir is the most common conifer species sprinkled in these riparian areas, although pondercas pine and grand fir (along Keithiy Creek) can also occus.

Mountain alder/water birch and mountain alder/willow are two associations we observed within the HMP Area. The former appears related to Miller's (1970) Alnus incana/Bowula occidentalis community type. This cover type occurs where there is permanent streamflow. We did not sample any mountain aider communities and it is difficult to correlate them to other classified communities. Kauffiman et al. (1985), Kovalchik (1987), Evenden (1989), Padget et al. (1989), Crowe and Clausnimer (1995), Hansen et al. (1995), and Manning and Padget (1995) all describe mountnin alder community types that may be applicable to one degree or another, although none seen fully satisfactory for the HMP Ares.

White alder (Alnus thombifolia: AINRBO) - This cover type is restricted to Mama Creek and confluent lower Adams Creek. It is characterized by a white alder overstory and a diverse multi-layer shrub understory. Common shrube include red-osier dogwood, syringa, Wood's rose, blsck bawthorne, common snowberry, Rocky Mountain maple, and golden currant. Herbaceous cover is variable. Black cottonwood trees protrude above the white alder in some sections to form a discontinuous upper canopy, along with a mix of some dead and decadent trees. The white alder carnopy is mostly closed, but varies to being open in some stretches. The width of the white alder riparian zone varies from less than $10 \mathrm{~m}$, to greater than $30 \mathrm{~m}$.

White alder communities dominate many tributaries of the lower Salwon, lower Clearwater, and Snake river canyons. Mann Creek approaches the southernmost extension of white alder in Idaho. The most comprehensive regional treatment of white aider is by Milles (1970). Huschle (1975) and Daubenmire (1970) also describe white alder types. Mancuso and Moseley (1995) include \& white alder cover type for their Browalee area vegetation map. Casul inspection suggest white alder along Mano and lower Adams creeks is related to Miller's (1970) Alnus rhombifolia/Philadebhus lewisil community type.

Organization of the vegetation map

The vegetation map consists of 154 polygors, numbered 1 to 154 . The numbering sequence begins in the 
southeastern portion of the HMP Ares and scrolls to the north and west. Polygons 1-80 and 119-154 are located east of Mann Creek, while polygons 81-118 are to the west. Polygons 1-41 occur largely on the Midvale Hill quadrangle, polygon 42-118 largely on the Mann Creek NW quadrangle, polygons 119-141 largely on the Sturgill Peak quadrangle, and 142-154 largely on the Hopper Creek quadrangle. Riparian polygons are usually long and linear in shape. In several cases, these long polygons encompass more than one cover type. Adjacent upland polygon numbers are used to reference descriptive information for the tiparian vegetation along a particular stream segment. The width of most riparian polygons exaggerates the actual width of the riparian vegetation. This was unavoidable for the sake of clarity.

The size of the HMP Area is approximately 27, 740 acres (Bureau of Land Management 1994). The GISgenerated vegetation map entails 27,317 acres. This discrepancy is party due to the omission of Fairchild Reservoir and other smaller stock reservoirs in the calculations. Another likely contributing factor is the imprecise match of the actual HMP Area boundaries with the approximate boundaries delineated for the vegetation map.

Classification of the vegetation map is besed on 13 cover types. Each polygon is assigned a primary cover type reflecting the dominant vegetation. The polygon descriptions also contain information regarding cover type inclusions, ecological condition, and other descriptive informstion. The vegetation of a particular area within the HMP Area can be determined by referencing the appropriate polygon description. It is necessary to have a copy of the vegetation map to determine which polygon covers a particular area.

The thyme-leaved buckwheat (ERTMY) and Gray's biscuitroot (LOMGRA) cover types occur only as inclusions. The interwediate wheat (AGRINT) and white alder (ALNRHO) cover types occur in only one polygon apiece. Polygons with the reric sagebrush (ARTTRX) and rock buclwheat (ERISPH) cover types are the most comnoon and cover the greatest ares. The mounnin shrub (MTSHRUB) cover type is the most common inclusion. Polygon range in size from 1,879 acres (polygon "37). Mean polygon size is approximately 177 acres. Table 3 summarizes the frequency of each cover type, while Table 4 summarizes the extent and average polygon size for each cover type. Because they occur only or maicly as inclusions, screages for the ARTARB, ERTIHY, and LOMGRA cover types are not accurately reflected in the vegetation map. Appendir 2 list the cover type, size (acreage), inclusions, and ecological condition assersment for each polygon.

\section{Ecological condition asesement}

Seral staus is a key factor in appraising wildlife habitat (Thoms 1979). One of our objectives for the vegetation map was to provide an ecological assessmem of selected habitas within the HMP Area. Our approach was to assign ecological rambs on an individual polygon basis. Because not all cover types are conducive to ready ecological assessmem we limited our assessmem to polygons dominated by sagebrush, grassland, and scabland cover types. The assignments represent our best judgement based on rapid ocular survey method. No quantitutive sampling was done. The majority of poly gons are comprised of vegetation supporting a mix of seral conditions. Ecological rank aseignnents reflect the overall and predominant status of the polygon's vegetation. For some polygons this is best expressed as a range of ecological ranks. The ecological rasks are based on saquential stages of retrogression from the sites netural potential vegetation (climas). The natural poteatinal vegetation equates to the habitat type for a given site. The ecological ranks are slightly modified from Johnson and Simon (1987) and defined as follows:

Climax - the stable state when species composition and density do not change appreciably over time and 
Table 3. Cover type frequencies for the HMP Area vegetation map.

\begin{tabular}{llll}
\hline & \multicolumn{2}{c}{ Erequency } \\
& Brimary cover type (g) & 'Cover type as an inclusion \\
ARTTRX & 42 & $(27)$ & 29 \\
ARTARB & 2 & $(1)$ & 9 \\
AGRSPI & 15 & $(10)$ & 6 \\
POABUL & 7 & $(5)$ & 1 \\
AGRINT & 1 & $(<1)$ & 0 \\
ERISPH & $29(19)$ & 15 \\
ERITHY & 0 & $(0)$ & 14 \\
LOMGRA & 0 & $(0)$ & 9 \\
MTSHRUB & $23(15)$ & 45 \\
PSEMEN & $18(12)$ & 9 \\
CRADOU & $13(8)$ & 4 \\
ALNINC & 3 & $(2)$ & 1 \\
ALNRHO & 1 & $(<1)$ & 0 \\
TOtal & & & 142
\end{tabular}

"Iaclusions for the MTSFRUB and CRADOU cover types are depicted on the vegetation map.

dominant species are reproducing.

Late seral - Climax species are present, but not at climax density and composition levels. Exotic species are present in only small amounts. Mid seral - The major climax species are present, but at rechiced density and composition. Associsted species sensitive to disturbance have a reduced abundance or may be missing, while species rending to increase with disturbence often occur in slewed abundance. Invading species are usually common.

Early seral - Major climax species are present, but in peril of being lost from the community. Native species that tend to increase with disturbence may be common. Invading species are abundant and usually dominate the vegetation. A disclimax will likely result if degradation contimes.

Very early seral - Climax species are abeant or so few as to malne antural recolonization highly unlikely. Invading species strongly dominate the vegetation. A disclimax exists, and generally only manipulative change can reintroduce native dominams, at least in the short term.

Disturbances throughout the AMP Are limit any climax stage vegetntion to small, fragmented areas. Livestock graxing and associated activities such as roeds, stoclponds, fencing, and vegetation treament are the most widespread disturbances within the HMP Ares. The construction of Fairchild Reservoir was a major local disturbance. Wildfires have had a large effect on vegetation patterns within the RMP Area. Disturbances caused by wildlife are also evident in places. The Hiron Preserve Field is a large fenced area in the southeastem quarter of the HMP Area that is no longer grazed by livestock. Most late seral 
Table 4. Total and relative extent, and average polygon size for the vegetation map cover types.

\begin{tabular}{lccc}
\hline & ${ }^{1}$ Aerialextent (acres) & Relative extent(\%) & Avg, polygon size (acres) \\
ARTTRX & 9,162 & 34 & 213 \\
ARTARB & 194 & $<1$ & 97 \\
AGRSPI & 4,761 & 17 & 317 \\
POABUL & 1,890 & 7 & 270 \\
AGRINT & 123 & $<1$ & 123 \\
ERISPH & 6,449 & - & 179 \\
ERTHY & - & - & - \\
LOMGRA & - & 9 & - \\
MTSHRUB & 2,431 & 4 & 97 \\
PSEMEN & 1,167 & 2 & 58 \\
CRADOU & 614 & 1 & 41 \\
ALNINC & 403 & $<1$ & 100 \\
ALNRHO & 122 & 100 & 122 \\
TOTAL & 27,317 & & 177 \\
\end{tabular}

${ }^{1}$ Acreages are approximate because additions and subtractions of aerial extert due to inclusions are not taken into account. The relative extent calculation is also approximate because it too is based on the primary cover type for each polygon, and therefore, does not tale into account inclusions. Because no polygons list them as the primary cover type (only inclusions), there are no values for ERTTHY or LOMGRA.

condition sagebrush-steppe habitat east of Mann Creek is found within this area.

Within the HMP Area, bulbous bluegrass is the most common invasive grass, followed by the anmual bromes, such as cheatgrass (Bromus tectorum). Very early or early seral condition vegetation is implicit for polygons containing the bulbous bluegrass cover type. Even late seral communities urually contain small amounts of these exotic species. Native forb species that tend to increase with livertock graning disturbance include yarrow, howksbeard, spurred lupine, and autumn willowweed. Salsify, thistles, and aumble mustard (Sisymbrium alsissinum) are exotic forbs commonly present in disturbed areas.

Different seral stages may apply for the different life-form layers within a community (Hall et al. 1995). Within the HMP Area, this most commonly applies to aress with the reric sagebrush/bluebunch wheatgrass habitat type. Sagebrush communities that burned and show no shrub regeneration are considered to have an early seral shrub layer. The associated herb layer may be late seral, however, if it is dominated by bluebunch whestgrass and other native species. Other permutntions are also possible. Seral status information is contained in the polygon descriptions. 
Polygon descriptions

Because of their importance as sharp-tailed grouse habitat, the location of mountain shrub (MTSHRUB) and black hawthorne (CRADOU) inclusions are included on the vegetation map. Forty-five polygons contain mountain shrub inclusions, and four contain black bawthorne inclusions large enough to be depicted on the vegetation map. In many cases there are more than one inclusion per polygor. Mounain shrub and black hawthorne inclusions are referenced in bold type in the following polygons description.

1. ARTTRX cover type - mix of early and mid-seral conditions; a few scattered deciduous shrubs. There is a small patch of mabire black cottonwood trees associated with a spring and old line shack.

2. ARTTRX cover type - mostly early seral in western, and mid-seral condition in eastera half of polygon; antelope bitterbrush is sparse in places, but well represented along ridges and upper slopes. There is an inclusion of late seral Artur/Fesida h.t. (with little sagebrush, but high antelope bitterbrush coverage, so perhaps Purtri/Fesida b.t.) on a steep north-facing slope in the northeastern part of the polygon. Site for plots $96 \mathrm{MMO03}$ and 004 .

3. CRADOU cover type - large and decadent willow shrubs (Saltr geyeriana and S. lasiandra) are abundant in stretches; riparian channel supports a band of wet meadow vegetation downstream from the polygon.

4. ERISPH cover type - bulbous bluegrass is most abundant associated grass; small inclusions of ERITHY.

5. AGRINT cover type - scattered individual or small patches of reric and low sagebrush, as well as antelope bitterbrush along ridgecrest.

6. ARTTRX cover type - mix of early and mid-ceral understory; few till decichous sarubs; only scattered small inclusions of ERISPH or open rocky aress; at least one ARTARB inclusion. Squawapple (006, part of 007 ) occurs within the polygon. The channel leading downstream from Fairchild Reservoir supports a strip of wet mesdow vegetntion with common spike-rush.

7. CRADOU cover type - a mix of deciduous shrub species associated with the black hawthorne; small wet meadows in adjacent bocomlands; site for plot 96MMOO1.

8. ERISPH cover type - mir of iate and mid-seral condition; smnll deciduous shrub pach at north end of polygon; site of plot $96 \mathrm{MMMON}$.

9. POABUL cover type - Artirz/Agrspi h. t. that has burned and is now largely a bulbous bluegrassdominated graseland; squirreltail is common in many places, while bluebunch wheatgrass is sparse except for a few scatred inclusions where it is more common; a few ARTTRX, ARTARB, and small MTSHRUB inclusions. There is evidence of mechnrical ripping over large areas aseociated with the BLM's sagebrush reseeding project. No sagebrush seedlings were observed during the spring, 1996.

10. ARTTRX cover type - Artiry/Fevida habitat type probably is late seral condition.

11. CRADOU cover type - there is a small chump of black cotromwoods, a small wet mesdow, and a 
patch of cattails (Typha larifolia) at head of spring.

12. ARTTRX cover type - mosty mid-seral, grading into early seral grassland vegetation similar to polygon $\# 9$ along its western edge.

13. ARTTRX cover type - Arttrz/Fesida h. t. probably in late seral condition.

14. ERISPH cover type - mid-seral with a few late seral portions; inclusions of ARTTRX on scattered mounds of deeper soil.

15. AGRSPI cover type - late seral condition; lots of rock rubble and talus streams with abundant hot rock penstemon (Penstemon deusius) on steep west-facing slope. The steep north-facing slope above Sage Creek supports Fesida/Agrspi h.t. and talus-shrub garlands. Located within the Buckwheat Flats RNA.

16. ERISPH cover type - with ARTTRX, and small inclusions of ERTHY and LOMGRA; mix of early and mid-seral conditions with bulbous bluegrass common throughout the flats. Located within the Buckwheat Flats RNA and site of plot 96MM010.

17. Sage Creek - ALNINC cover type in vicinity of polygon 22 , with Salix spp. and inclusions of CRADOU in the vicinity of polygons \# 9 and 10 . CRADOU cover type in vicinity of polygons \# 71 and 78; with biack cottonwood occurring in places, as does a dense tall shrub mix on the slopes adjacent to the creek. Upper Sage Creek in the vicinity of polygons \#133 and 75 is mostly PSEMEN cover type, with mixed deciduous shrub. This combination intrudes into polygon / 133 as depicted on the vegetation map.

18. POABUL cover type - bluebunch wheatgrass co-occurs on east-facing slopes; ARTTRX is scattered along toeslope and western one-third of polygon; inclusions of MTSHRUB consisting of stunted chokecherry clones on slopes, and mixed species in draw.

19. MTSHRUB cover type - shrubfields dominated by chokecherry intermixed within sagebrush vegetation that has burned. The deciduous shrubs have resprouted (some mortality), but most of sagebrush and antelope bitterbrush were killed. Bluebunch wheatgrass is prominent in openings.

20. AGRSPI cover type - burned (early seral) Arturz/Agrspi h.t. with few remnant shrubs and lots of bulbous bluegrass; herbaceous layer varies from early to late seral; several large ERISPH inclusions.

21. AGRSPI cover type - burned (early seral) Arturz/Agrspi h.t. with few shrubs remaining; bulbous bluegrass is common in places, and the berbaceous layer ranges from early and late seral.

22. AGRSPI cover type - burned (early seral) Arurd/Agrspi h.t. with all the sagebrush killed; bulbous bluegrass common, and Idaho fescue present on northerly inclusions.

23. ERISPH cover type - with inclusions of ERTHY and LOMGRA.

24. AGRSPI cover type - Artrx/Agrspi h.t. that has mostly burned; there is litule remnant sagebrush (early seral), and the berbaceous layer is mostly mid-seral. There are inclusions of MTSHRUB on eastfacing slopes, CRADOU stringers along drainge botom, and limited ERISPH. Idaho fescue occurs on some northerly exposures. 
25. ARTTRX cover type - with low of antelope bitterbrush, and inclusions of MTSHRUB domingted by chokecherry.

26. ERISPH cover type - with ERITHY in places; patches of ARTTRX are beavily grazed and degraded, and some areas interseeded with intermediate wheatgrass; MTSHRUB inclusions.

27. ARTTRX cover type - early seral understory; with MTSHRUB inclusions.

28. ARTTRX cover type - early seral understory with litule bluebunch wheatgrass remaining. MTSHRUB inclusions found in small draws and brow positions.

29. ERISPH cover type - inclusions of ARTTRX intermixed with MTSHRUB on northerly exposures and in draws, and ARTIRX with early seral understory on south-facing slopes.

30. ERISPH cover type - with ERITHY and AGRSPI inclusions.

31. CRADOU cover type.

32. CRADOU cover type.

33. AGRSPI cover type - burned Artwry/Agrspi h.t. with few shrube remaining; bulbous bluegrass is common in places; early seral, with a mostly mid-seral understory.

34. ERISPH cover type - with large inclusions of ERTHYY along ridgecrest; inclusions of ARTTRX and AGRSPI, both of which are grazed by livestock

35. AGRSPI cover type - burned (early seral) Artur/Agrspt b.t. with only a few shrubs remaining; understory is mostly mid-seral, with bulbous bluegrass being common in places. There is a patch of leafy spurge (Euphorbis esula) in the polygon.

36. ERISPH cover type - majority of area has burned; ERISPH is the most common scabland type in a mosaic that includes burned and unburned Artrr/Agrspi, and Agrspi-Poasec/Balsag h.t's. Unburned sagebrush vegetation supports an early to mid-seral understory, while bulbous bluegrass dominates the burned areas. Nearly all of the metive grasaland vegetition has burned and is early seral stage dominated by bulbous bluegrass, although Sandberg's bluegras is common in places. MTSHRUB inclusions have resprouted in moet places. Some burned areas may have been the Purti/Agropi h.t. Plot 90MM014 is located within the polygon.

37. "East Fork' Sage Creek - ALNINC cover type in vicinity of polygons 33 and 35 , with Salix spp. being a common aseociate, and interspersed with CRADOU and scattered Douglas-fir trees. CRADOU further upstream in the vicixity of polygon 36 and site of Plot 96MM013. The upper end of the drainge in the vicinity of polygon 146 apports CRADOU. There are inclusions of PSEMEN located near the plot, as well as MTSHRUB in small draws and slopes adjacent to the chamel.

38. MTSHRUB Cover type.

39. CRADOU cover type - Dry Creek; there are intermiment gaps in shrub coverage along the riparian 
corridor.

40. MTSHRUB cover type - within mosaic of ARTTRX and ERISPH.

41. ARTTRX cover type - mostly mid-seral; inclusions of MTSHRUB in draws and steep lee of ridgecrests that are heavily grazed; bittercherry and chokecherry abundant in places. There are also inclusion of CRADOU in riparian areas, and small areas with stiff sagebrush. Portions of polygon between Dry and Keithly creeks near the eastern boundary of the HMP Area have burned, and considerable sagebrush and bitterbrush regeneration was observed.

42. CRADOU cover type - Deer Creek; red-osier dogwood is a prominent associate.

43. ERISPH cover type - a few inclusions of ARTTRX.

44. POABUL cover type - burned flats that probably supported low sagebrush and xeric sagebrush habitat types.

45. ERISPH cover type - with late seral condition ERITHY community at north end of polygon.

46. ERISPH cover type - early wo mid-seral; with inclusions of ARTTRX and MTSHRUB.

47. AGRSPI cover type - burned (early seral) Arturz/Agrspi h.t.; the tall deciduous shrubs have resprouted nicely, but the sagebrush and bitterbrush are gone; MTSHRUB inclusions are common.

48. ARTARB cover type - extensive clay soils area; herbeceous layer is mostly mid-seral, but also early seral; squirreitail is more common than bluebunch wheatgrass in places; patches of mixed MTSHRUB. Plot $96 \mathrm{MM} 009$ is located in this polygon. The channel leading downstream from Fairchild Reservoir supports a strip of wet meadow vegetation with common spike-rush. There are no tall shrubs along the channel.

49. ERISPH cover type - scablands vegetation is more common along western balf of polygon, while ARTARB dominates the eastern half. There are small inclusions of MTSHRUB along lee of loolls and small patches of ARTTRX associated with tops of inolls. Squawapple (portion of 007) occurs within the polygon.

50. MTSHRUB cover type - mixed shrub species with lots of snowbrush ceanothus and bluebunch wheatgrass common in the openings. Bittercherry dominates the point ridge in the southern part of the polygon. Squawapple $(005)$ occurs within the polygon.

51. ARTTRX cover type - the more gentle upper slopes are mostly late seral condition with lots of antelope biturbrush, a few widely scattered western juniper (Juniperis occidentalis) trees and frequent MTSHRUB inclusions that are dominated by bittercherry in most cases. Large portions of the steep midto lower slopes support Agrspi-Poasec/Balsag h.t., with high rock cover and inclusions of talus-shrub garlands.

52. ARTTRX cover type - mostly mid-seral; a few low density patches of MTSHRUB; patches of scotch thistle occur around reservoir; location of plot 96MMO07. 
53. ERISPH cover type - ERITHY common; mostly late seral condition; location of plot $96 \mathrm{MM} 008$.

54. MTSHRUB cover type - within an ARTTRX matrix.

55. POABUL cover type - burned Artura/Agrspi h.t. with scattered small inclusions of ARTARB and ERISPH that did not burn; bluebunch wheatgrass is rare in flats, but more common on gentle slopes.

Corral is located in northern section of polygon.

56. MTSHRUB cover type - within an ARTTRX matrix.

57. CRADOU cover type - location for plot 96MM016.

58. ARTTRX cover type - mix of burned and unburned sagebrush habitat; inclusions of ERISPH and MTSHRUB.

59. ARTTRX cover type - with extensive MTSHRUB inclusions, and one of PSEMEN with deciduous shrubs at northern end of polygon; also inclusion of Artarb/Fesida h.t.

60. ERISPH cover type - late to mid-seral condition; minor amounis of ERITHY.

61. MTSERUB cover type - patches of shrubs within a sagebrush matrix; approximately equal amounts of shrubfields and sagebrush; ditch bisects polygon.

62. ARTARB cover type - late to mid-seral condition; location of plots 96MMOOS and 96MMO06.

63. ARTTRX cover type - diverse vegetation with frequent inclusions of MTSHRUB that are typically dominated by bittercherry, and patches of PSEMEN. Inclusions of ARTARB (Artarb/Poasec and Artarb/Agrspi h.t's.)

64. PSEMEN cover type - southern balf of polyson supports Dougias-fir with a all shrub understory dominated by bittercherry, with Rocity Mountain maple, and aspen (Populbus sremuloides); also portions with mostly common snowberry. Northen half of polygon is dominated by deciduous shrub vegetation, mostly bittercherry.

65. AGRSPI cover type - majority of slope supports grassland vegetation, including places in late seral condition. Sagebrush is absem or sparse except along more gentle upper slopes. Antelope bitherbrush occurs more consistently, but at low density. There are inclusions of PSEMIEN, small deciduous shrub patches, and thiss-shrub garlands, ss well as rock outcrops and talus streanos. The upper ridgecrest contains lace seral scablands dominnted by ERISPH, with small amounts of ERITHY and Artrig/Poasec.

66. ERISPH cover type - scabland-dominated vegetation in a mosaic with ARTIRX with inclusions of ERITHY aod ARTARB.

67. ERISPH cover type - commonly in a mosaic with ARTTRX; inclusions of MTSHRUB in draws and easterly slopes, and also ARTARB (Artarb/Poasec h.t.).

68. MTSHRUB cover type - within a mosaic of ARTTRX; cholecherry is abundamt; small inclusions of 
ERISPH.

69. ERISPH cover type - inclusions of ARTTRX varying from late to early seral condition, and strips of MTSHRUB.

70. ARTTRX cover type - mostly unburned, with early and mid-seral areas; inclusions of ERISPH and MTSHRUB.

71. ARTTRX cover type - burned and unburned, with high sagebrush and antelope bitterbrush mortality in the burned portions; early and mid-seral berbaceous vegetation in burned areas; MTSHRUB has resprouted well with lots of chokecherry.

72. ERISPH cover type - with inclusions of ERITHY, and AGRSPI in spots where sagebrush burned.

73. CRADOU cover type - greater shrub density, including some Douglas-fir trees in upstream portion of polygon.

74. POABUL cover type - southern, more gently sloping portions of polygon support a mix of POABUL, ERISPH and ARTTRX. The steep east-facing slopes in northern half of polygon are dominated by POABUL with scabland inclusions and a few MTSHRUB stands. Uncertain how much of polygon burned.

75. AGRSPI cover type - steep, open slopes with rocky and/or scabland inclusions; ERISPH occurs on broad spur ridge faces; ARTTRX on slopes above draws with MTSHRUB in the draw bottoms. Bulbous bluegrass is abundant in places, and vegetation is in early to mid-seral condition.

76. "West Fork" Sage Creek - CRADOU cover type in vicinity of polygons " 58 and 59 . The hydrology of this area has been altered by a transbasin ditch to Fairchild Reservoir. Further upstream in the vicinity of polygon 120 , the riparian vegetation is comprised of dense tall shrubs. We are unsure if black hawthorne dominates this stretch. Scattered Douglas-fir trees are also present.

77. "Middle Fork" Sage Creek - CRADOU cover type in vicinity of polygon " 68, with inclusions of ALNINC. Associated species include black cotronwood, Rocky Mountain maple, and peach-leaved willow (Salix anygdaloides).

78. ARTTRX cover type - the sagebrush is sparse in places; inclusions of ERISPH, especially near the Forest Service boundary; MTSHRUB dominated by cholecherry in places, and PSEMEN in upper end of polygon.

79. MTSHRUB cover type - gentle valley with many seeps and springs, with abundant chokecherry, and CRADOU patches associated with several of the seeps; ARTARB inclusions in clayey areas along bottoms.

80. ALNRHO cover type - Mann Creek riparian zone.

81. AGRSPI cover type - sperser vegetrtion and more rock on southerly aspects; some sagebrush and antelope bitterbrush; inclusion of PSEMEN near Mamn Creek. Mostly mid-seral, but with areas in late seral condition. 
82. ARTTRX cover type - mostly late and mid-seral; mosaic vegetation that also includes ERISPH and MTSHRUB.

83. PSEMEN cover type - Psemen/Phymal h.t.; shrubby canopy openings dominated by bittercherry; small inclusions of Arttra/F esida h.t.

84. MTSHRUB cover type - with scattered small clumps and individuals of Douglas-fir; ARTTRX inclusions in open areas.

85. AGRSPI cover type - mostly late and mid-seral; antelope bitterbrush (many of them dead) widely scattered across the slope; a little sagebrush in places; rock outcrops and talus streams common; inclusions of talus-shrub garlands.

86. AGRSPI cover type - steep grassland slopes in late to mid-seral condition; inclusions of ARTTRX along moderate more stable upper slopes; deciduov: shrub strip along lower slopes adjacent to Mann Creek.

87. ARTTRX cover type - mid- to late seral; with open areas supporting Agrspi-Poasec/Balsag h.t., plus scattered deciduous shrubs.

88. PSEMEN cover type - Psemen/Symalb and Psemen/Phymal h.t's; the western one-third of the polygon has a more open, spotty canopy with larger shrubfields.

89. ARTTRX cover type - largely mid-seral; in a mosaic with lots of scabland vegetation domingted by LOMGRA. Fence along ridge is in disrepair.

90. ARTTRX cover type - a mosaic with MTSRRUB dominated by bithercherry; mostly mid-seral.

91. PSEMEN cover type - Psemen/Phymal the dominant habitat type; with interspersed shrubfield and sagebrush vegetation.

92. ARTTRX cover type - mostly late seral, with some areas mid-seral; MTSHRUB inclusions (with scattered Douglas-fir) are common and comprise about $35 \%$ of the polygon; minor ERISPH inclusions.

93. ARTTRX cover type - with some deciduous shrubs near Fir Creek; moetly mid-seral.

94. PSEMEN cover type - Psemen/Symalb and perhaps some Psemen/Calrub habitat types; there are some large trees within this polygon. The Fir Creek riparian zone contains Douglas-fir, with gaps dominated by black hawthome.

95. ARTTRX cover type - mid-seral; with more antelope bitterbrush than sagebrush.

96. ARTTRX cover type - in a mosaic pattern with MTSHRUB patches usually dominated by bittercherry, scabland vegetation, and minor amounts of ARTARB that are associated with the rocky channels of ephemeral creek bottoms near the western edge of HMP area. A mix of early and mid-seral herbaceous layer. 
97. ERISPH cover type - in a mosaic with rocky AGRSPI; varies from late seral to early seral in vicinity of stock pond.

98. PSEMEN cover type - Psemen/Symalb habitat type; the western $30 \%$ of polygon contains scattered Douglas-fir intermized with large patches of MTSHRUB.

99. AGRSPI cover type - mostly mid-seral; with LOMGRA in some of the many rocky inclusions; ARTTRX along the more stable upper slope positions; small draws dissecting slope with stringers of mixed species MTSHRUB.

100. PSEMEN cover type - Psemen/Phymal habitat type.

101. MTSHRUB cover type - largely talus-shrub garlands, with inclusions of AGRSPI in open areas.

102. MTSHRUB cover type - multi-layered shrubfields generally domingted by bittercherry, with some intermixed Douglas-fir.

103. ARTTRX cover type - mid-seral; more antelope bitterbrush than sagebrush.

104. POABUL cover type.

105. ARTTRX cover type - a range of seral stages; several MTSHRUB inclusions, and small scabland openings.

106. PSEMEN cover type - twin polygons with Douglas-fir and a mixed deciduous shrub understory.

107. ERISPH cover type - patterned ground topography with inclusions of ERITHY and small patches of ARTTRX.

108. MTSHRUB cover type - with nearly equal amounts of ARTTRX in southern part of polygon that is mostly mid-seral, but varies from early to late; the shrub patches are dominated by Prumus spp. and vary from dense to open; a few small ERISPH inclusions.

109. PSEMEN cover type - open canopy with dense deciduous shrub layer with lots of bittercherry.

110. PSEMEN cover type - open canopy with deciduous shrub understory.

11. ARTTRX cover type - with a well developed sagebrush and antelope bitterbrush layer; inclusions of MTSHRUB. Herbaceous layer varies from early to mid-seral areas.

112. ARTTRX cover type - late and mid-seral except near stock reservoirs; MTSHRUB inclusions are common and usually dominated by bittercherry; shrubfields in draws may also contain black hawthome, aspen, or occasionally Douglas-fir; several scabland inclusions.

113. CRADOU cover type - aspea/black hawhorne patches occur in polygon; there is also a narrow wet meadow complex alongside the creek. 
114. ARTTRX cover type - gently undulating topography; occurring on slightly raised areas as a mosaic with ARTARB in the intervening poorly drained swales; bulbous bluegrass dominates the early seral herbaceous layer in both sagebrush types.

115. ARTTRX cover type - mosaic vegetation with many MTSHRUB inclusions; bulbous bluegrass is the predominant grass in flatter areas, while bluebunch wheatgrass is common on the slopes; mid-seral condition overall; scabland inclusions.

116. PSEMEN cover type - with mixed deciduous shrub understory; fire scars blacken the bases of most of the conifers.

117. MTSHRUB cover type - includes areas with scattered shrubs interspersed within a mid-seral bluebunch wheatgrass matrix; antelope bitterbrush is the most common shrub in places; Idaho fescue present on north-facing slope.

118. ARTTRX cover type - mid-seral; with scattered serviceberry shrubs, and grading into POABUL near southern boundary of the HMP Area; rock outcrop/cliff inclusion.

119. MTSHRUB cover type - bittercherry is most common shrub; intermixed with patches of ARTTRX, and small PSEMIEN inclusions.

120. ERISPH cover type - MTSHRUB inclusions; also with small inclusions of ERTTHY and ARTTRX.

121. PSEMEN cover type - with aspen and mired deciduous shrubs.

122. ERISPH cover type-mid-seral.

123. PSEMEN cover type - Psemen/Symalb habitat type; in eastern section of polygon, small forest stands occur in a mosaic with shrubfield and sagebrush habitats; inclusions of ARTTRX.

124. ERISPH cover type.

125. MTSHRUB cover type - with scattered PSEMEN and small amounts of ARTTRX.

126. PSEMEN cover type - Psemen/Symalb habitat type; with some ponderosa pine in the stand.

127. ARTTRX cover type - with inclusions of ERISPH and MTSHRUB.

128. ERISPH cover type - with small inclusions of MTSHRUB, and AGRSPI on steeper slopes.

129. MTSHRUB cover type.

130. MTSHRUB cover type - with scattered iodividual and patches of Douglas-fir; Scouler's willow (Salix scouleri) is common in upper end of polygon.

131. CRADOU cover type - some Douglas-fir in places. 
132. ERISPH cover type.

133. ARTTRX cover type - with common inclusions of MTSHRUB; widely scattered Douglas-fir, especially on slopes above and in draws; a few small ERISPH inclusions.

134. MTSHRUB cover type - with scattered Douglas-fir.

135. PSEMEN cover type.

136. ARTTRX cover type - this area is probably dominated by the Arttrx/Agrspi h.t. However, we did not visit this area and are uncertain how much, if any burned, and present vegetation patterns. The polygon may be a mosaic of unburned sagebrush-antelope bitterbrush and bluebunch wheatgrass- and/or bulbous bluegrass-dominated areas.

137. ARTTRX cover type - with extensive MTSHRUB inclusions, especially along upper slopes and in draws; late and mid-seral areas.

138. MTSHRUB cover type - bittercherry and chokecherry dominate the upper slopes, but nearly pure stands of mallow ninebark occur along some mid- and lower-slope positions. Blackened snags scattered throughout the polygon indicate past fire, although several clumpe of Douglas-fir survived the burn. ARTIRX, but with much more antelope bitterbrush than sagebrush, occurs across lower slopes.

139. PSEMEN cover type - mostly the Psemen/Symalb habitat type; mixed deciduous shrubfields occur in openings.

140. POABUL cover type - mosaic of open grassland vegetation that includes areas of mid-seral AGRSPI, scabland vegetation dominated by LOMGRA with minor amounts of Artrig/Possec h.t., and MTSHRUB in draws. Most of antelope bitterbrush has ben killed by fire and appears to have been much more common than sagebrush (perhaps a bitterbrush and not sagebrush habitat type?).

141. PSEMEN cover type - Psemen/Phymal habitat type across most of slope, with sections of Psemen/Symalb. There are a few small scattered burned area. Small patches of Abigra/Spibet occur along upper Keithly Creek near the north end of HMP Ares. Forest vegetation is regularly interrupted with open areas supporting AGRSPI grasslands. Deciduous shrubfields often dominated by mallow ninebark are locally associated with many forest margin and open areas.

142. ERISPH cover type - with inclusions of LOMGRA, and Artrig/Poasec b.L

143. AGRSPI cover type - early and mid-seral; bulbous bluegrass is common, including as part of the LOMGRA inclusions; a few shrubfield inclusions in small draws.

144. MTSHRUB cover type - shrubs are most dense in small draws and along steep upper to mid-slopes. This area has burned, with snags still standing in places, but scattered individual and small patches of Douglas-fir remain. There is an inclusion of PSEMIEN with aspen and dense bittercherry in the understory. The southern half of polygon is largely ARTTRX with deciduous shrub inclusions.

145. PSEMEN cover type - riparian area containing Douglas-fir with mired deciduous shrubs; the 
Douglas-fir is sparse in segments, where get inclusions of CRADOU.

146. ERISPH cover type - LOMGRA is also common in this mosaic with ARTTRX; bulbous bluegrass is abundant and sagebrush babitats are mostly early seral. Location for plot $90 \mathrm{MM} 015$.

147. MTSHRUB cover type - dominated by bittercherry with some Douglas-fir intermixed; inclusion of PSEMEN with disturbed understory adjacent to stock reservoir.

148. MTSHRUB cover type - some aspen mixed in.

149. PSEMEN cover type - mostly Psemen/Phymal babitat type; some burned snags along top margin of stand.

150. ARTTRX cover type - mix of burned and unburned vegetation, nearly all in early seral condition; inclusions of ERISPH, including large example around Point 4367, at southern end of polygon.

151. MTSHRUB cover type - within sagebrush matrix.

152. ARTTRX cover type - a mosaic of sagebrush stands largely degraded and with an early seral understory (some mid-seral portions), scabland vegetation consisting mainly of LOMGRA, and frequent MTSHRUB in draws and adjacent sideslopes. The shrubfields vary from mixed species, to being dominated by bittercherry or mallow ninebark.

153. MTSHRUB cover type - in a mosaic with ARTTRX that supports a mostly early seral understory. Shrubfields are mostly dominated by bitercberry, although some petches dominated by mallow ninebark or mixed species. Part of polygon has burned in the past and apparently supported stands of Douglas-fir.

154. ALNINC cover type - Keithly Creek riparinn zone. Upstrenm from where Forest Service rond drops down to Keithly Creek the riparian vegetation is cominated by mountain alder, with water birch common in stretches. For the most part, black cottonwood occurs as scattered individuals or small clumps, but is more common over few short areas. The riparian vegetation was not surveyed downstream from the Forest Service road, but is likely the same.

\section{Vegetation sampling}

Several plant communities within the HMP Area bave not been quantitatively sampled and classified, or have received only minimal investigation. The relationship between communities located in west-cantral Idaho and other regional classifications is often unclear due to the paucity of ecological sampling of nonforest habitats in the ares. We conducted a limited amount of ecological sampling to quamify selected community types. This information wes useful for comparisons to existing claseifications, to write the cover type descriptions for the vegetation map, and to document undescribed types. A total of 16 plots were sampled in six community types (Table 5). Exch community type was sampled at three sites except for Lomartum groyt/Pou secuonda, which was sampled at only one site. Plots are referenced using a unique alpha-mumeric code (plot code) and numbered 96MM001 to 96MM016. Plot locations are mapped (Appendix 4), and species cover and constancy information summarized for each community (Appendix 3). 
Table 5. Plant community types sampled in the HMP Ares.

Community type

Antemisia tridenasa ssp. xericensis/Agropyron spicanm

Artemisia arbuscula/Agropyron spicarum

Eriogonum sphaerocephalum/Poa secunda

Eriogonum thymoides/Poa secunda

Lomatium grayi/Poa secunda

Crasaegus douglasii
Ploc code numbers

$003,004,007$

$005,006,009$

$002,008,015$

$010,012,014$

011

$001,013,016$

Plots were subjectively located in areas that appeared representative of the particular community type. Sampling was conducted in areas supporting late seral vegetation when possible. Upland plots were $10 \mathrm{~m}$ by $10 \mathrm{~m}$ in sire, while riparian plots were $25 \mathrm{~m}$ long and varied from 7-10m wide. Plow were not permanently marked. Sampling protocol follows Bourgeron et al. (1991), and Western Heritage Task Force Forms II and III were completed for each plot. The complete set of original data sheets are on file at the CDC office in Boise, with copies at the BLM's Lower Snake River District office in Boise. A sample of these field forms are in Appendir 5.

Rare plants

Cursory searches for rare plants were incorporated into our vegetation map field work. No new populations of BLM Sensitive or other rare plant species were discovered during this field work. Squawapple is the only rare plant species previously known to occur within the HMP Area. Potential habitat for at least two other species, Dermatocarpon (Dermasocarpon lorenzianum) and Snake River goldenweed (Haplopoppus radianus) is found within the HMP Area.

Squawapple (Rerapholloun ramosissionum)

Squawapple (Peraphylum namosissimum) is an intricately and rigidly branched deciduous shrub. It is the only BLM Sensitive plant species documented to occur within the KMP Ares. Peraphyllum is a monotypic genus in the rose (Rosaceae) family. It distribution extends from north-central Oregon, south along the east side of the Sierras through central Californin, and east to western Colorado and northeastern New Mexico (Shaw et al. 1991).

In Idaho, squawapple is known only from the Weiser/Mann Creek area in Washington County. Eastem Oregon populations of squawapple are restricted to a narrow transitional belt along the sagebrush and pondeross pine forest interface, between 4,200 and 4,500 feet elevation (Johnson and Simon 1987). The nearest Oregon populations are found in the LaGrande area. Most populations in Idaho occur within the sagebrush-steppe zone below 4,000 feet elevation, usually in association with other shrub species.

Within the HMP Ares, squawapple is known from three occurrences (CDC occurrences 005, 006, and 007 ) south of Fairchild Reservoir (Figure 3). We did not discover any new populations during our vegetation map surveys. We revisited two occurrences $(005,007)$ and obtained updated information (Appendix 6). The original location information associsted with occurrence 007 was somewhat vague. This 


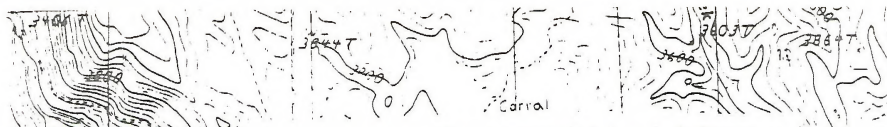

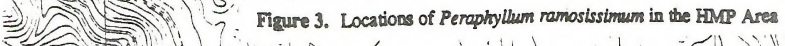

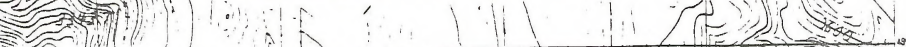

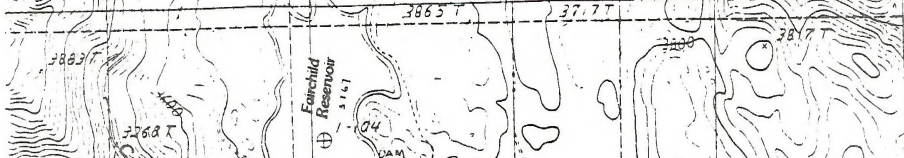

(a)

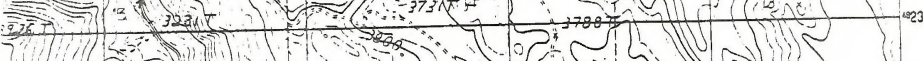

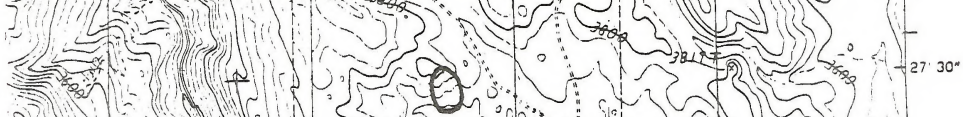

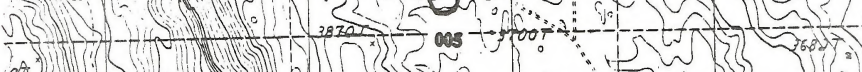

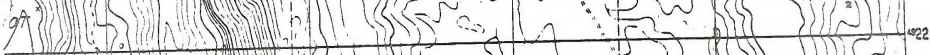
var sey (a)

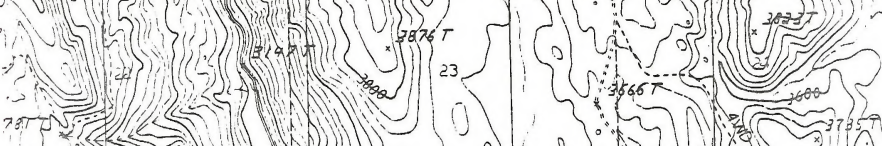

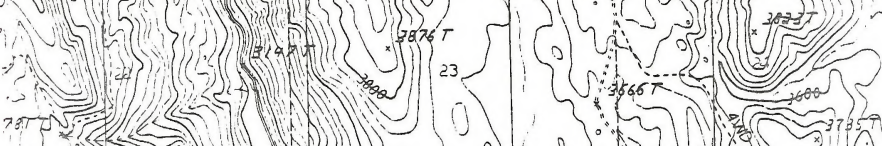
(2) (a) (T)

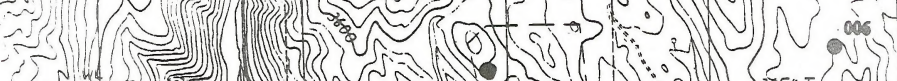

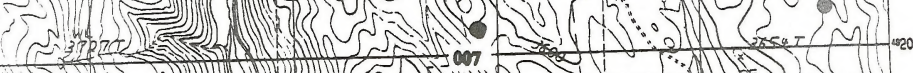
3 3)

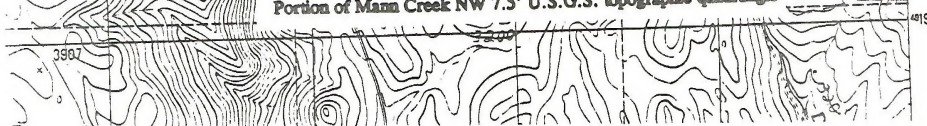


occurrence is now known to be located a little south of where it was previousiy mapped, and consists of two separate subpopulations. We did not relocate occurrence 006 , and its status is unimown.

Forage value of squawapple varies throughout its range (Smith 1974). Beside being browsed by wildlife and livestock, the fruits are used by birds and rodents. Plants from the HMP and nearby areas tend to be severely hedged, indicating their high palatability. Nearly all fruits were aborted on plants we observed in 1996. Additionally, few if any seedlings have been observed in recent years at sites that have been visited. Detailed information is lacking for the known occurrences within the HMP Area. Establishing monitoring plots, or at least reference photo points would help track these occurrences over time. The monitoring plan being developed for the HMP Area should incorporate squawapple populations as much as possible. Minimizing further deterioration of existing squawapple babitat is probably the most important conservation measure at known sites. Protecting and monitoring existing squawapple occurrences should receive priority over supplemental plantings.

Supplemental planting of squawapple within the HMP Area will require initial research regarding appropriate seed or rootstock availability. Seed collecting may be necessary to acquire sufficient material of the regional ecotype. When dealing with species of conservation concern such as squawapple, it is important to consider the long-term consequences of diluting the local genetic structure with introductions from other areas. Squawapple populations in Idaho are small and located along the periphery of the species' main distribution. These populations may be important from a conservation standpoint (Lesica and Allendorf 1992). We recommend using local seed or rootstocls material for any squawapple augmentation within the HMP Area.

Initial survival of squawapple plantings is otten low. Seedings grow slowly and may require protection for up to three years post-planting, but it is very persistent once established. The existence of distinct ecotypes that are possibly restricted to specific soil types makes selection of appropriate seed sources important (Shaw et al. 1991). Information regarding growing and planting squawapple is contained in several publications (Stark 1966; Smith 1974; Vories 1981; Belcher 1985; and Shaw et al. 1991).

Logical places for squawapple plantiags would be sites with similar environmental and vegetation characteristics as nearby existing occurrences. Three general areas contain potentially suitable habitat - (1) near Fairchild Reservoir (portions of polygons 47, 52,59,61, 63, and the upper slopes of polygons 51 and 65); (2) the soutbeastern corner of the HMP Area (polygons 1, 2, and segments in 6, which is a large polygon); and (3) west of Mam Creek (portions of polygons 115 and 118). Mountain shrub planting as identified in the HMP, has been oagolng for several years. Squawapple plantings may be easier to accomplish in conjunction with these other shrub plantings. If supplemental squawapple planting is pursued, we recommend one to three initial sites be chosen, depending on the amount of material available. Monitoring and assesement of these sites should be conducted before \& much larger effort is undertaken. Seed collection and rootstock production can be ongoing chring this experimental period. This may require BLM coordination with a mursery or other cooperator.

\section{Dermatocacpon (Dermatocarpon lorendanum)}

Dermatocarpon is a small, grayish-colored, sqamulose lichen that grows attached to basalt pebbles in dry exposed habitats. It is apparently rare in North America, where only a few sites in California, Oregon, and Idaho are known (McCune and Goward 1995). In Idaho, dermatocarpon has been collected only from near the gravel pit near Midvale Hill, although it may extend into the nearby Buckwheat Flats RNA (R. 
Rosentreter, Idaho BLM State Botanist, pers. comm., 1996). It is a BLM Sensitive species in Idaho (Conservation Data Center 1990). We did not observe the lichen within the RNA or HMP Area. We purposefully searched for dermatocarpon at only a few select sites, and it is possible we overlooked the lichen due to our inexperience with this species.

\section{Snake River goldenweed (Hoplopapous madianus)}

Snake River goldeaweed is another BLM Sensitive plant species that potentially could occur within the HMP Area. No Snake River goldenweed was observed while conducting our field work for the vegetation map. Several populations of the robust form of the closely related Columbia goldenweed (Haplopapprss carthamoides var. carthomoides) were found around Fairchild Reservoir. These populations contain individual plants which could pass as Srake River goldenweed. Other populations of Columbia goldenweed likely occur within the HMP Area. Information to help differentiate these two similar goldenweed tara has been outlined (Mancuso and Moseley 1993).

\section{Buckwheat Flats Research Natural Area}

As part of our vegetation survey, we revisited the Buckwheat Flats RNA. Beside collecting information for the vegetation map, we also evaluated the area's conservation status and whether current management is consistent with BLM policy. The RNA consists of two segments, and is 200 acres in size (Figure 4). The eastern haif of the RNA is located approximately 0.3 mile outside the HMP Area and supports a diverse vegetation. Scabby aress support Eriogonum sphaerocephatum/Poa secunda, Eriogonuens thymoides/Poa secunda, and Lomartum groyi/Poa secunda plant communities. Plot $96 \mathrm{MM} 011$ is located in an example of the L. grayi/P. secunda cover type. Steep slopes in the center of the 80 acres burned during the early $1990^{\prime}$ 's. Western and northeastern-facing slopes support Agropyron spicatum-Poe secunda/Balsamonira sagirtara grassland vegetation that are mostly in mid-seral condition. Northern aspects east of Point 3363 support a few acres of the Fesnuce idahoensis/Agropyron spicanum habitat type. A patch of leafy spurge occurs in a small draw in this ares (see Appendix 1). Many of the individusal and small clumps of chokecherry scattered across these slopes burned, with apparently only spoty regeneration. Northeastern portions of the RNA support stands of Purshia tridentasa/Agropyron spicanum, with at least one small area also containing some Idaho fescue. The vegetation across State IKighway 95 appears to be mostly disturbed Artemisia tridentata ssp. zericensis/Agropyron spicanum, and limited amounts of scabland. The only lnown Idaho location for the BLM Sensitive lichen species Demavocarpon lonenzianum (dermstocarpon) is near the gravel pit adjacent to the RNA. It also possibly occurs in the RNA. We did not observe the lichen within the RNA, but could have overloolbed it due to our inexperience with this species.

Several factors are compromising the eagtern 80 acre block of the RNA. Most seriously is expansion of the gravel pit closer to the RNA. There is a minor two-track roed lesding from the pit ares to the northwestern corner of the RNA, and Highway 95 dissects the southenstern corner. Cattle were observed grazing just north of the RNA, and cowpies were scsttered within it boundaries. There are no ferces ro prevent: livestock acceasing the RNA from the Sage Creak area. Bulbous bluegrass and annual bromes are well established within the RNA and a small patch of leafy spurge has been discovered.

The 120 acre westem balf of the RNA is located within the HMP Ares. The gentle broad ridge complex is dominated by scabland vegetation. Eriogonum sphaerocephahum/Poa secunda is the most common community type, with smaller areas conkining Eriogonum thymoides/Pos secumda and minor amounts of Lomatiun grayi/Poa secuonda. Plot $99 \mathrm{MM} 010$ wes located in one of the Eriogonum thymoldes/Poes secunda 

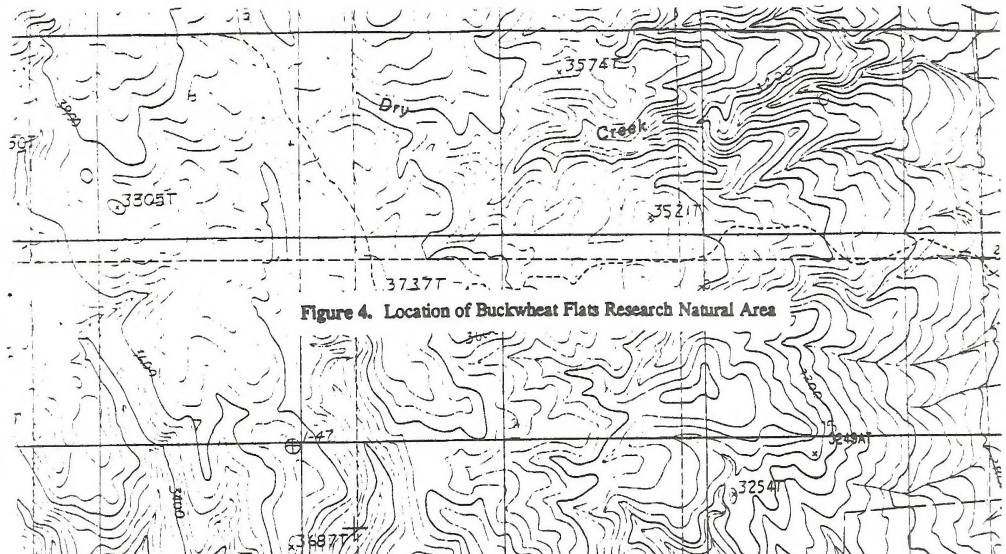

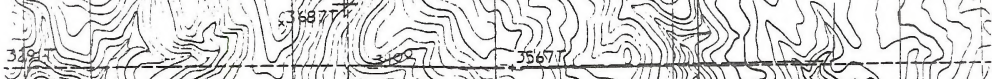

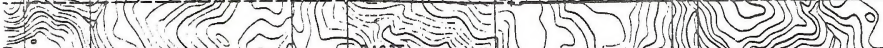

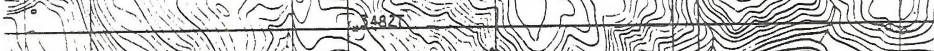

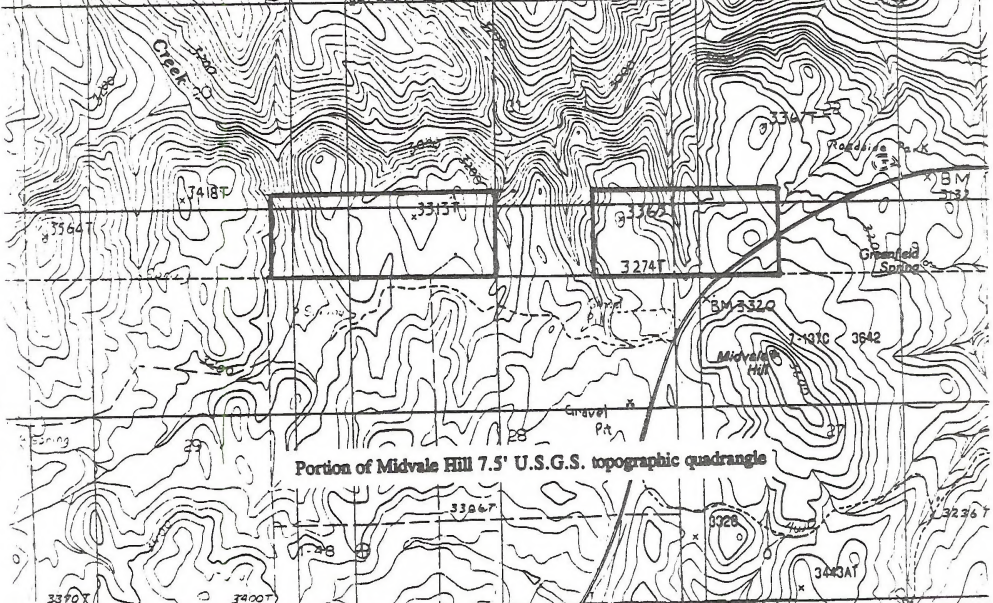

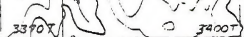

$2=17$

$\sqrt{0} \sqrt{0} \sqrt{2})$

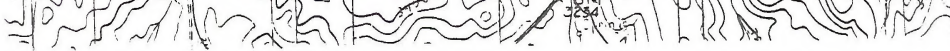


communities. Artemisia tridentate ssp. xericensis/Agropyron spicanum and perhaps Purshio

iridentata/Agropyron spicatun also occur along the broad ridgetop. These tall shrub areas contin abundant bulbous bluegrass with a mainly early seral herb layer. Bulbous bluegrass is also established within most scabland areas. Late seral condition Agropyron spicatum-Poa secunda/Balsamohiza sagirtata occurs along the steep, rocky, west to northeast-facing slopes above Sage Creek and a main tributary. Talus-sbrub garlands also occur in this area. The steep north-facing slope above Sage Creek supports a Festuce idahoensis/Agropyron spicarum community in late seral condition. The western block of the RNA appears to be secure from threats, although cattle graze adjacent areas quite heavily, and weedy grasses are well established. Fences appeared to be intact in the areas we walked.

The Buclwheat Flats RNA was primarily establisbed for its representation of Eriogonum sphaerocephalum/Poc secunda and Eriogonum thymoides/Poa secunda scabland vegetation. Lomatium grcsyi/Poa secunda is another scabland community type represented within the RNA. A Resource Management Plan Maintenance to change the boundaries of the RNA has been proposed by the BLM. The proposal would terminate the RNA designation for the 80 acres outside the HMP Ares, north of Midvale Hill, and transfer the designation to T13N, RAW, Sec $20 \mathrm{NE1/4} \mathrm{SE1/4} \mathrm{and} \mathrm{SE1/4} \mathrm{NE1/4.} \mathrm{The} \mathrm{transferred}$ 80 acres would be contiguous with the existing western block of the RNA and within the FMP Area. One possible drawback of the proposal is losing RNA protection for an area that may be habitat for the rare lichen dermatocarpon. Despite this concem, we recommend the BLM proceed with the Plan Maintenance for several reasons:

1. The portion of the RNA to be terminated is jeopardized by several threats that are difficult to mitigate.

2. The proposed transfer lands are located within the HMP Ares and would afford the RNA an additional level of resource protection. The transfer will increase the prospects for the RNA's longterm conservation.

3. The proposed mansfer lands iscludes the steep west- and north-facing slopes above Sage Creek that were part of TNC's original RNA recommendation beck in the mid-1980's. This ares sroports grassland vegetation in excellent cological condition. The transfer also includes a segment of Sage Creek and its associated riparian vegetation, and adds to the diversity of habitat protected by the RNA.

4. The transfer will consolidate the RNA into a single block of land and facilitate management.

Scabland vegetation is widespresd throughout the HMP Ares, with the most extensive aress locand north of Sage Creek and the RNA. There are additional large scabland habitas along the ridges east of Fairchild Reservoir that are within the "Firos Preserve Field" and not grazed by livestock. This area probably contains the least threatened scablund vegetation in the HMP Ares and any conservation plans for scabland vegetation types should include the "Fixon Preserve Field" as well.

\section{Sharp-tailed groues cbecrvedions}

During our field work, we observed sharp-tailed grouse on three separate occasions (Appendix 7). Three birds (adults?) were flushed from a grassy area on May $30 \mathrm{~h}$, in T13N, R4W, Sec 30 (polygon / 9). On May 31st, a single bird was obeerved in a saddle area in T13N, RSW, Sec 13 (polygon 447 ). A hen and three chicles were seen on June 5th south of Fairchild Reservoir in T13N, RSW, Sec 14 (polygon I 48). 


\section{References}

Belcher, E., chairman. 1985. Handbook on seeds of browse-shrubs and forbs. Technical Publication R8TP8. Allanta, GA: USDA, Forest Service, Southern Region. Prepared by the Browse, Shrub-Forb Committee of the Association of the Official Seed Analysis.

Bourgeron, P.S., R.L. DeVelice, L.D. Engelking, G. Jones, and E. Muldavin. 1991. WHTF site and community survey manual. Version 92B. Western Heritage Task Force, Boulder, CO. 24 p.

Bureau of Land Management. 1994. Hixon Columbian sharp-tailed grouse Habitat Management Plan. Unpublished report on file at Bureau of Land Management, Lower Snake River District, Boise, ID. 30 p., plus appendices.

Conservation Data Center. 1996. Biological and Conservation Dat System, Element tracking files (December 1996), Idaho Department of Fish and Game, Boise, ID.

Crowe, E.A, and R.R. Clausnitzer. 1995. Mid-montane wethands classification of the Malheur, Umatilla, and Wallowa-Whitman National Forests. USDA, Forest Service, Pacific Northwest Region, Wallowa-Whitman National Forest, Baker City, OR. 188 p., plus appendices. Draft.

Daubenmire, R. 1970. Steppe vegetation of Washington. Technical Bulletin 62. Pullman, WA: Washington Agricultural Experiment Station. 131 p.

Ertter, B., and B. Moseley. 1992. Floristic regions of Idaho. Journal of the Idaho Academy of Science 28:57-70.

Evenden, A.G. 1989. Ecology and distribution of riparian vegetation in the Trout Creek Mountains of southeastern Oregon. Ph.D. Dissertation. Oregon State University, Corvallis, OR. 128 p.

Fitzgerald, J.F. 1982. Geology and basalt stratigraphy of the Weiser Embayment, west-central Idaho. Pages 103-128, In: Cenozoic geology of Idaho; B. Bonnichsen, and R.M. Breckenridge eds. Idaho Bureau of Mines and Geology, University of Idaho, Moscow.

Grossman, D.H., K.L. Goodin, and C.L. Reuss, eds. 1994. Rare plant communities of the conterminous United States. An initial survey. Prepared by The Nature Conservancy, Arlington, VA. 620 p.

Hall, F.C. 1973. Plant communities of the Blue Mountains of Oregon. R6-ECOL-79-001. USDA, Forest Service, Pacific Northwest Region, Portland OR.

Hall, F.C., L. Bryan, R. Clausnitzer, K. Geier-Hayes, R. Keane, J. Kertis, A. Shlishy, and R. Steele. 1995. Definitions and codes for seral status and structure of vegetation. Gen. Tech. Rep. PNW-GTR363. Portland, OR: USDA, Forest Service, Pacific Northwest Research Station. 39 p.

Hansen, P.L., R.D. Pfister, K. Boggs, B.J. Cook, J. Joy, and D.K. Hincley. 1995. Classification and management of Montans's riparian and wetland sites. Miscellaneous publication No. 54. University of Montana, Montans Forest and Conservation Experiment Station, School of Forestry, Missoula. $646 \mathrm{p}$. 
Hironaka, M., M.A. Fosberg, and A.H. Winward. 1983. Sagebrush-grass habitat types of southern Idabo. Bulletin No. 35. Forest, Wildlife and Range Experiment Station, University of Idaho, Moscow. 44 p.

Hitchcock, C.L., and A. Cronquist. 1973. Flora of the Pacific Northwest. University of Washington Press, Seattle, WA. 730 p.

Huschle, G. 1975. Analysis of the vegetation along the middle and lower Snake River. M.S. Thesis. University of Idaho, Moscow. 271 p.

Johnson, C.G., and S.A. Simon. 1987. Plant associations of the Wallowa-Snake Province. R6-ECOLTP-255A-86. USDA, Forest Service, Pacific Northwest Region, Wallowa-Whiman National Forest, Baker City, OR. 399 p., plus appendices.

Johnson, F.D. 1981. Idaho: climate/vegetation life zone data. Forestry, Wildlife aod Range Science Experiment Station, University of Idaho, Moscow.

Kauffman, J.B., W.C. Krueger, and M. Vavra. 1985. Ecology and plant communities of the riparian area associated with Catherine Creek in northeastem Oregon. Agricultural Experiment Station Technical Bulletin 147. Oregon Sente University, Corvallis. 35 p.

Kovalchik, B.L. 1987. Riparian zone associations of the Deschutes, Fremont, Ochoco and Winema National Forests. R6-ECOL-TP-279-87. USDA, Forest Service, Pacific Northwest Region, Portiand, OR. $171 \mathrm{p}$.

Lesica, P., and F.W. Allendorf. 1992. Are small populations worth preserving? Conservation Biology $6(1): 135-139$.

Mancuso, M. 1995. A vegetation map of the Rocking M Ranch, upper Demett Creek/Raft Creek Wildlife Conservation Easememt Area, Washington County, Idaho. Unpublished report on file at Idaho Department of Fish and Game, Boise, ID. 38 p., plus appendices.

Mancuso, M., and R. Moseley. 1993. Report on the conservation status of Haplopappus radiarus in Idaho. Status survey report prepared for the Idaho Department of Parls and Recreation, Boise, DD. 32 p., plus appendices.

Mancuso, M., and R. Moseley. 1995. A vegetation map for Brownlee Wildife Management Area, Washington County, Idaho. Unpublished report on file at Idaho Deparment of Fish and Game, Boise, ID. 72 p., plus appendices.

Manning, M.E., and W.G. Pedget 1995. Riparian community type classification for Humboldt and Toiyabe National Forests, Nevada and eastern California. R4-8COL-95-01. USDA, Forest Service, Intermountain Region, Ogden, UT. 306 p. 
Marks J.S., and V. Saab Marks. 1987. Habitat selection by Columbian sharp-tailed grouse in west-central Idaho. Unpublished report on file at Bureau of Land Management, Lower Snake River District, Boise, ID. 115 p.

McCune, B., and T. Goward. 1995. Macrolichens of the northern Rocky Mountains. Mad River Press, Eureka, CA. 208 p.

McNab, W.H., and P.E. Avers, compilers. 1994. Ecological subregions of the United States: Section descriptions. WO-WSA-5. USDA, Forest Service, Washington, D.C.

Miller, T.B. 1976. Ecology of riparian communities dominated by white alder in western Idaho. M.S. Thesis, University of Idaho, Moscow. 154 p.

Mitchell, V.E., and E.H. Bennet, compilers. 1979. Geologic map of the Baker quadrangle, Idaho. 1:250,000 scale. Idaho Bureau of Mines and Geology, Moscow, ID.

Omernik, J.M., and A.L. Gallant. 1986. Ecoregions of the Pacific Northwest. EPA/600/3-86/033. U.S. Environmental Protection Agency, Eavironmental Research Laboratory, Corvallis, OR. 39 p.

Padget, W.G., A.P. Youngblood, and A.H. Winward. 1989. Riparian community type classification of Utah and southeastern Idaho. Gen. Tech. Rep. R4-ECOL-89-01. Ogden, UT: USDA, Forest Service. 191 p.

Roberts, R.W. 1971. Bitter cherry vegetation on the Boise National Forest. M.S. Thesis, University of . Idaho, Moscow. 53 p.

Rosentreter, R., and R.G. Kelsey. 1991. Xeric big sagebrush, a new subspecies in the Arremisia tridentata complex. Journal of Range Management 44(4):330-335.

Ross, S.H., and C.N. Savage. 1967. Idaho earth science: geology, fossils, climate, water, and soils. Idaho Bureau of Mines and Geology, Earth Science Series No. 1, Moscow, ID. 271 p.

Shaw, N.L., Monsen, S.B., and R. Stevens. 1991. Chapter IV-3, Rosaceae In: Monsen, S.B., and R. Stevens, compilers; Restoring range and wildlife habitat in the Intermountain Region. Gen. Tech. Rep. Ogden, UT: USDA, Forest Service, Intermountain Research Station. Draft.

Smith, J. 1974. Peraphylhum ramosissimum Nutu. Pages 576-577 In: Seeds of woody plants in the United States; C.S. Schopmeyer, Technical Coordinator. Agricultural Handbook No. 450. USDA, Forest Service, Washington D.C.

Soil Conservation Service. 1992. Soil survey of Adams-Washington area, Idaho, parts of Adams and Washington counties. Drat.

Stark, N. 1966. Review of highway planting information appropriate to Nevada. College of Agriculture Bulletin No. B-7. Desert Research Institute, University of Nevada, Reno. 
Steele, R., R.D. Pfister, R.A. Ryker, and J.A. Kittams. 1981. Forest babitat types of central Idaho. Gen. Tech. Rep. INT-114. Ogden, UT: USDA, Forest Service, Intermountain Forest and Range Experiment Station. 138 p.

Steele, R., and K. Geier-Hayes. 1989. The Douglas-fir/ninebark babitat type in central Idaho: succession and management. Gen. Tech. Rep. INT-252. Ogden, UT: USDA, Forest Service, Intermountain Research Station. 65 p.

Steele, R., and K. Geier-Hayes. 1993. The Douglas-fir/pinegrass habitat type in central Idaho: succession and management. Gen. Tech. Rep. INT-298. Ogden, UT: USDA, Forest Service, Intermountain Research Station. 83 p.

Thomas, J.W., tech. ed. 1979. Wildlife habitats in managed forests: the Blue Mountains of Oregon and Washington. Agricultural Handbook 553. USDA, Forest Service, Washington, D.C. 512 p.

Tisdale, E.W. 1986. Canyon grasslands and associated shrublands of west-central Idaho and adjacent areas. Bulletin No. 40. Forest, Wildlife, and Range Experiment Station, University of Idaho, Moscow. 42 p.

Vories, K.C. 1981. Growing Colorado plants from seed: a state of the art. Vol. I: Shrubs. Gen. Tech. Rep. INT-103. Ogden, UT: USDA, Forest Service, Intermountain Research Station. 80 p.

Winward, A.H., and E.W. Tisdale. 1977. Taronomy of the Artemisia tridentata complex in Idaho. Bulletin No.19. Forest, Wildlife, and Range Experiment Station, University of Idaho, Moscow. 15.p. 
Vegetation Map for the Hixon Columbian Sharp-tailed Grouse Habitat Management Plan Area

The cover type for each polygon is explained in the text.

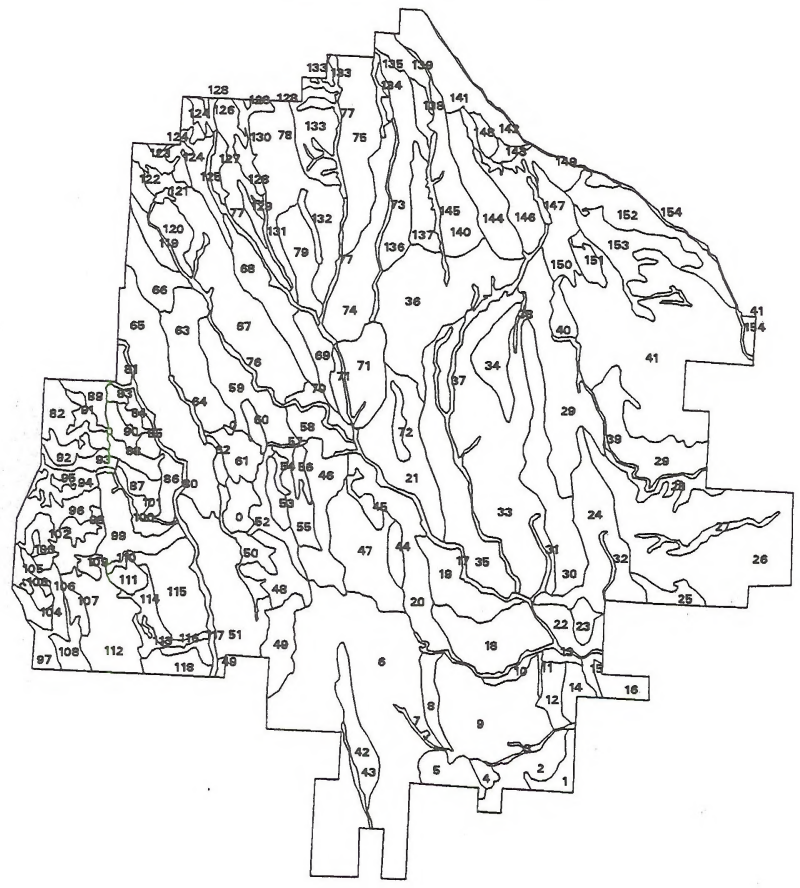

1:24,000 scale copies of the vegetation map are available from the Conservation Data Center (Idaho Department of Fish and Game, P.O. Box 25, 600 S. Walnut, Boise, ID 83707). 

Appendix 1

Locations of leafy spurge (Euphorbia esula) within the MMP Area.

Map 1. Portion of Midvale Hill 7.5' U.S.G.S. topographic quadrangle.

Map 2. Portion of Midvale Hill 7.5' U.S.G.S. topographic quadrangle. 



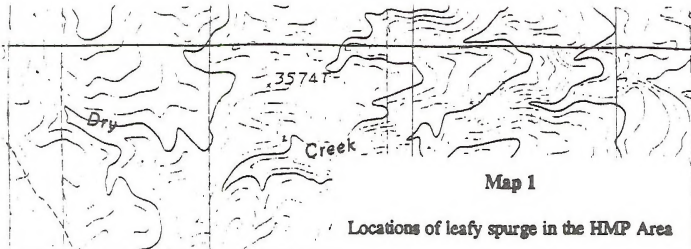

\section{Locations of leafy spurge in the HMP Ares}

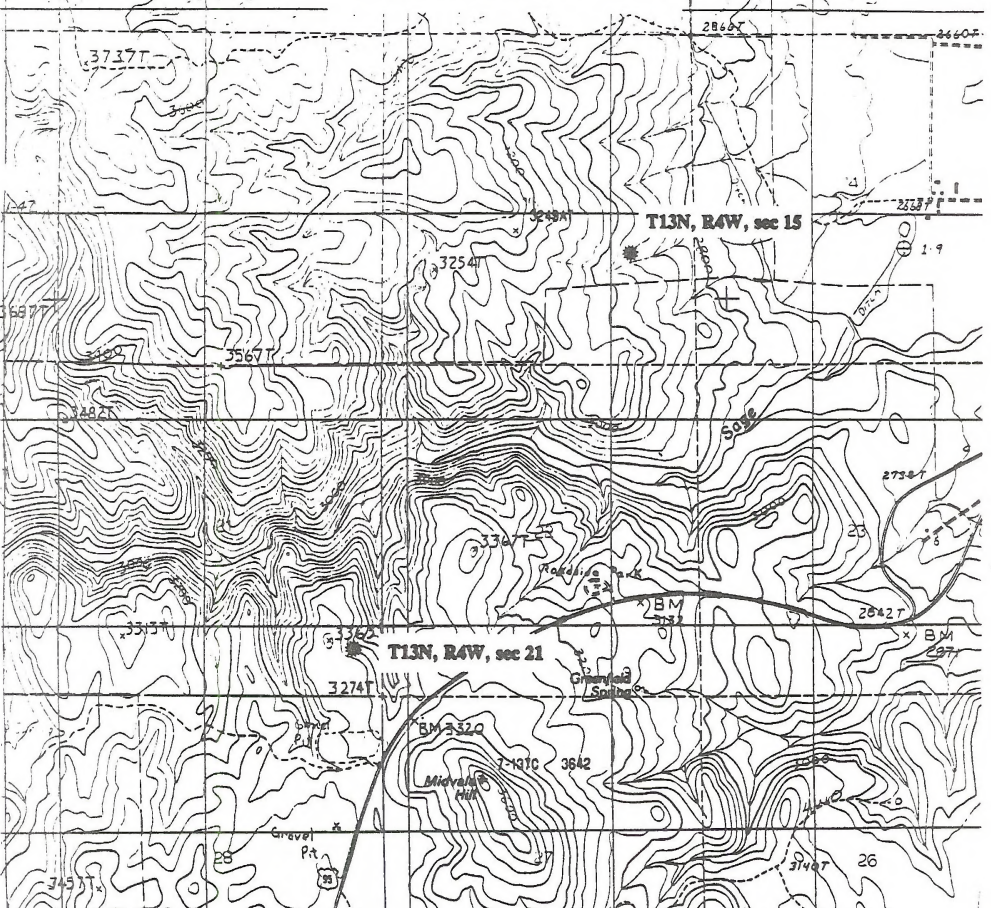

$=100 \times$ 


\section{DEPARTMENT OF THE INTERIOR GEOLOGICAL SURVEY}
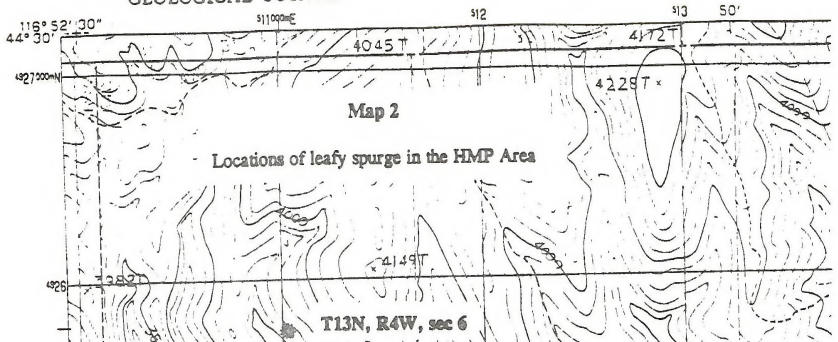

(v)

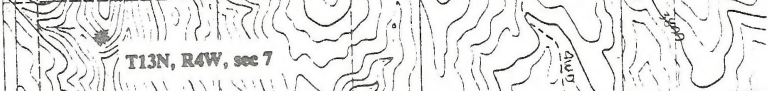

h h

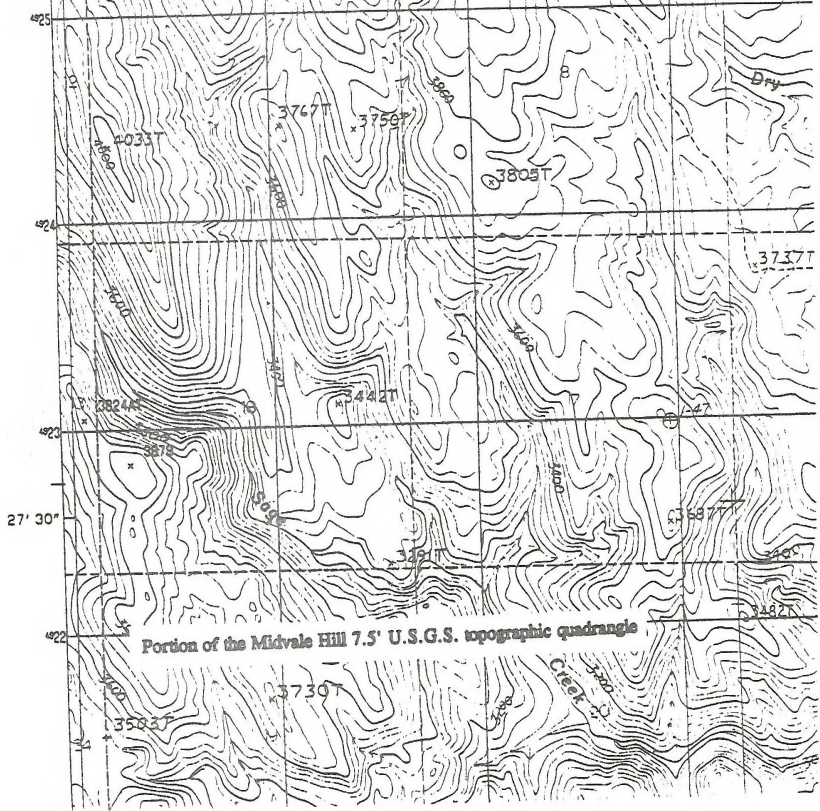


Appendix 2

Size, cover type, inclusions, and ecological condition summary for the vegetation map polygons.

Interpretation of Appendix 2:

Polygon : The vegetation map is comprised of 154 polygons (map units), numbered 1 to 154 .

Size Polygon size in acres as determined by GIS.

Cover type The cover type code names are provided in Table 2.

Inclusion

$$
\begin{array}{ll}
1=\text { ARTTRX } & 8=\text { LOMGRA } \\
2=\text { ARTARB } & 9=\text { MTSHRUB } \\
3=\text { AGRSPI } & 10=\text { PSEMEN } \\
4=\text { POABUL } & 11=\text { CRADOU } \\
5=\text { AGRINT } & 12=\text { ALNINC } \\
6=\text { ERISPH } & 13=\text { ALNRHO } \\
7=\text { ERITHY } &
\end{array}
$$

Ecological condition $Y=$ yes, the selected ecological condition occurs in the polygon $\mathrm{N}=\mathrm{no}$, the selected ecological condition does not occur in the polygon $0=$ no ecological condition assessed for the polygon 

Size, cover type, inclusions, and ecological condition summary for the vegetation map polygons.

\begin{tabular}{|c|c|c|c|c|c|c|}
\hline \multirow[t]{2}{*}{ Polygon " } & \multirow[t]{2}{*}{ Sizo } & \multirow[t]{2}{*}{ Cover type } & \multirow[t]{2}{*}{ Inchusions } & \multicolumn{3}{|c|}{ Ecological condition } \\
\hline & & & & Early seral & Mid-seral & Late seral \\
\hline 1 & 83 & ARTTRX & & $\mathrm{Y}$ & $Y$ & $\mathbf{N}$ \\
\hline 2 & 189 & ARTTRX & & $\mathrm{Y}$ & $\mathbf{Y}$ & $\mathbf{N}$ \\
\hline 3 & 27 & CRADOU & & 0 & 0 & 0 \\
\hline 4 & 34 & ERISPH & & 0 & 0 & 0 \\
\hline 5 & 123 & AGRINT & & $Y$ & $\mathbf{N}$ & $\mathbf{N}$ \\
\hline 6 & 1,879 & ARTIRX & 2 & $Y$ & $\mathbf{Y}$ & $\mathrm{N}$ \\
\hline 7 & 17 & CRADOU & & 0 & 0 & 0 \\
\hline 8 & 90 & ERISPH & & $\mathrm{N}$ & $\mathbf{Y}$ & $Y$ \\
\hline 9 & 606 & POABUL & $1,2,9$ & $Y$ & $\mathbf{N}$ & $\mathrm{N}$ \\
\hline 10 & 33 & ARTTRX & & $N$ & $\mathrm{~N}$ & $\mathrm{Y}$ \\
\hline 11 & 12 & CRADOU & & 0 & 0 & 0 \\
\hline 12 & 94 & ARTTRX & & $\mathrm{N}$ & $\mathrm{Y}$ & $\mathrm{N}$ \\
\hline 13 & 27 & ARTTRX & & $\mathrm{N}$ & $\mathrm{N}$ & $\mathrm{Y}$ \\
\hline 14 & 80 & ERISPH & 1 & $\mathrm{~N}$ & $Y$ & $Y$ \\
\hline 15 & 33 & AGRSPI & & $\mathrm{N}$ & $\mathbf{N}$ & $\mathbf{Y}$ \\
\hline 16 & 90 & ERISPH & $1,7,8$ & $Y$ & $\mathbf{Y}$ & $\mathbf{N}$ \\
\hline 17 & 172 & ALNINC & 11 & 0 & 0 & 0 \\
\hline 18 & 349 & POABUL & 1,9 & $Y$ & $N$ & $\mathrm{~N}$ \\
\hline 19 & 238 & MTSHRUB & & 0 & 0 & 0 \\
\hline 20 & 358 & AGRSPI & & $Y$ & $\mathrm{Y}$ & $Y$ \\
\hline 21 & 402 & AGRSPI & & $Y$ & $Y$ & $\mathbf{Y}$ \\
\hline 22 & 121 & AGRSPI & & $\mathbf{Y}$ & $\mathrm{N}$ & $\mathrm{N}$ \\
\hline 23 & 58 & ERISPH & 7,8 & 0 & 0 & 0 \\
\hline 24 & 463 & AGRSPI & 9,11 & $\mathbf{N}$ & $Y$ & $\mathbf{N}$ \\
\hline 25 & 79 & ARTTRX & 9 & 0 & 0 & 0 \\
\hline 26 & 1,158 & ERISPH & $1,7,9$ & 0 & 0 & 0 \\
\hline 27 & 73 & ARTTRX & 9 & $Y$ & $\mathrm{~N}$ & $\mathbf{N}$ \\
\hline 28 & 99 & ARTIRX & 9 & $Y$ & $\mathrm{~N}$ & $\mathrm{~N}$ \\
\hline
\end{tabular}




\begin{tabular}{|c|c|c|c|c|c|c|}
\hline \multirow[t]{2}{*}{ Polygon " } & \multirow[t]{2}{*}{ Sizo } & \multirow[t]{2}{*}{ Cover type } & \multirow{2}{*}{ Inchusions } & \multicolumn{3}{|c|}{ Ecological condition } \\
\hline & & & & Early seral & Mid-soral & Leto seral \\
\hline 29 & 868 & ERISPH & 1,9 & 0 & 0 & 0 \\
\hline 30 & 431 & ERISPH & 3,7 & 0 & 0 & 0 \\
\hline 31 & 26 & CRADOU & & 0 & 0 & 0 \\
\hline 32 & 16 & CRADOU & & 0 & 0 & 0 \\
\hline 33 & 1,037 & AGRSPI & & $\mathrm{N}$ & $Y$ & $\mathbf{N}$ \\
\hline 34 & 177 & ERISPH & $1,3,7$ & 0 & 0 & 0 \\
\hline 35 & 533 & AGRSPI & & $\mathrm{N}$ & $Y$ & $\mathbf{N}$ \\
\hline 36 & 730 & ERISPH & 9 & 0 & 0 & 0 \\
\hline 37 & 171 & ALNINC & 11 & 0 & 0 & 0 \\
\hline 38 & 13 & MTSHRUB & & 0 & 0 & 0 \\
\hline 39 & 58 & CRADOU & & 0 & 0 & 0 \\
\hline 40 & 70 & MTSHRUB & 1,6 & 0 & 0 & 0 \\
\hline 41 & 1,433 & ARTTRX & 9,11 & $\mathrm{~N}$ & $\mathbf{Y}$ & $\mathbf{N}$ \\
\hline 42 & 26 & CRADOU & & 0 & 0 & 0 \\
\hline 43 & 176 & ERISPH & 1 & 0 & 0 & 0 \\
\hline 44 & 60 & POABUL & & $\mathrm{Y}$ & N & $\mathbf{N}$ \\
\hline 45 & 49 & ERISPII & 7 & 0 & 0 & 0 \\
\hline 46 & 279 & ERISPR & 1,9 & $Y$ & $Y$ & $\mathrm{~N}$ \\
\hline 47 & 374 & AGRSPI & 9 & $\mathrm{Y}$ & $Y$ & $\mathbf{N}$ \\
\hline 48 & 164 & ARTARB & 9 & $\mathrm{~N}$ & $\mathrm{Y}$ & $\mathbf{N}$ \\
\hline 49 & 177 & ERISPY & $1,2,9$ & 0 & 0 & 0 \\
\hline 50 & 116 & MTSHRUB & & 0 & 0 & 0 \\
\hline 51 & 458 & ARTIRX & 9 & $\mathbf{N}$ & $\mathbf{N}$ & $\mathbf{Y}$ \\
\hline 52 & 121 & ARTTRX & 9 & N & $\mathrm{Y}$ & $\mathbf{N}$ \\
\hline 53 & 61 & ERISPH & 7 & $\mathbf{N}$ & $\mathbf{N}$ & $\mathrm{Y}$ \\
\hline 54 & 24 & MTSHRUR & 1 & 0 & 0 & 0 \\
\hline 55 & 124 & POABUL & 2,6 & $Y$ & $\mathrm{~N}$ & $\mathbf{N}$ \\
\hline 56 & 44 & MTSHRUB & 1 & 0 & 0 & 0 \\
\hline 57 & 8 & CRADOU & & . & 0 & 0 \\
\hline
\end{tabular}




\begin{tabular}{|c|c|c|c|c|c|c|}
\hline \multirow[t]{2}{*}{ Polygon } & \multirow[t]{2}{*}{ Sizos } & \multirow[t]{2}{*}{ Cover type } & \multirow[t]{2}{*}{ Inchusions } & \multicolumn{3}{|c|}{ Ecological condition } \\
\hline & & & & Early sernl & Mid-eenal & Lato seral \\
\hline 58 & 119 & ARTTRX & 6,9 & $\mathbf{Y}$ & $\mathbf{Y}$ & $\mathbf{N}$ \\
\hline 59 & 283 & ARTTRX & 9,10 & 0 & 0 & 0 \\
\hline 60 & 41 & ERISPH & 7 & $\mathbf{N}$ & $\mathrm{Y}$ & $\mathbf{Y}$ \\
\hline 61 & 122 & MTSFRUB & & 0 & 0 & 0 \\
\hline 62 & 30 & ARTARB & & $\mathbf{N}$ & $\mathbf{Y}$ & $\mathbf{Y}$ \\
\hline 63 & 345 & ARTIRX & $2,9,10$ & 0 & 0 & 0 \\
\hline 64 & 23 & PSEMMEN & & 0 & 0 & 0 \\
\hline 65 & 586 & AGRSPI & $6,7,10$ & $\mathrm{~N}$ & $\mathbf{Y}$ & $\mathbf{Y}$ \\
\hline 66 & 182 & ERISPH & $1,2,7$ & 0 & 0 & 0 \\
\hline 67 & 659 & ERISPH & $1,2,9$ & 0 & 0 & 0 \\
\hline 68 & 259 & MTSHRUB & 1,6 & 0 & 0 & 0 \\
\hline 69 & 113 & ERISPH & 1,9 & $\mathbf{Y}$ & $\mathbf{Y}$ & $\mathbf{Y}$ \\
\hline 70 & 59 & ARTTRX & 6,9 & $\mathrm{Y}$ & $\mathbf{Y}$ & $\mathbf{N}$ \\
\hline 71 & 286 & ARTIRX & 9 & $\mathbf{Y}$ & $\mathbf{Y}$ & $\mathbf{N}$ \\
\hline 72 & 53 & ERISPH & 3,7 & 0 & 0 & 0 \\
\hline 73 & 46 & CRADOU & & 0 & 0 & 0 \\
\hline 74 & 402 & POABUL & $1,6,9$ & $Y$ & $\mathbf{N}$ & $\mathbf{N}$ \\
\hline 75 & 430 & AGRSPI & $1,6,9$ & $\mathbf{Y}$ & $\mathbf{Y}$ & $\mathbf{N}$ \\
\hline 76 & 105 & CRADOU & & 0 & 0 & 0 \\
\hline$\pi$ & 212 & CRADOU & 12 & 0 & 0 & 0 \\
\hline 78 & 550 & ARTIRX & $6,9,10$ & 0 & 0 & 0 \\
\hline 79 & 180 & MTSHRUB & 2 & 0 & 0 & 0 \\
\hline 80 & 122 & ALNRHO & & 0 & 0 & 0 \\
\hline 81 & 31 & AGRSPI & 10 & $\mathrm{~N}$ & $Y$ & $Y$ \\
\hline 82 & 151 & ARTIRX & 6,9 & $\mathbf{N}$ & $Y$ & $\mathbf{Y}$ \\
\hline 83 & 20 & PSEMAEN & & 0 & 0 & 0 \\
\hline 84 & 33 & MTSHRUB & 1 & 0 & 0 & 0 \\
\hline 85 & 59 & AGRSPI & & $\mathrm{N}$ & $\mathbf{Y}$ & $\mathbf{Y}$ \\
\hline 86 & 81 & AGRSPI & 1 & $\mathrm{~N}$ & $Y$ & $Y$ \\
\hline
\end{tabular}




\begin{tabular}{|c|c|c|c|c|c|c|}
\hline \multirow[t]{2}{*}{ Polygon : } & \multirow[t]{2}{*}{ Sizo } & \multirow[t]{2}{*}{ Cover type } & \multirow[t]{2}{*}{ Inclusions } & \multicolumn{3}{|c|}{ Ecological condition } \\
\hline & & & & Early seral & Mid-esenl & Lato seral \\
\hline 87 & 72 & ARTTRX & & $\mathrm{N}$ & $\mathbf{Y}$ & $Y$ \\
\hline 88 & 70 & PSEMEN & & 0 & 0 & 0 \\
\hline 89 & 74 & ARTTRX & 8 & $\mathrm{~N}$ & $\mathrm{Y}$ & $\mathrm{N}$ \\
\hline 90 & 53 & ARTTRX & 9 & $\mathbf{N}$ & $\mathbf{Y}$ & $\mathbf{N}$ \\
\hline 91 & 48 & PSEMEN & & 0 & 0 & 0 \\
\hline 92 & 70 & ARTTRX & 6,9 & $\mathrm{~N}$ & $\mathbf{Y}$ & $Y$ \\
\hline 93 & 59 & ARTTRX & & $\mathrm{N}$ & $Y$ & $\mathbf{N}$ \\
\hline 94 & 112 & PSEMEN & & 0 & 0 & 0 \\
\hline 95 & 13 & ARTTRX & & $\mathrm{N}$ & $Y$ & $\mathrm{~N}$ \\
\hline 96 & 249 & ARTTRX & 2,9 & $Y$ & $Y$ & $\mathbf{N}$ \\
\hline 97 & 150 & ERISPH & 3 & $\mathbf{Y}$ & $Y$ & $\mathbf{Y}$ \\
\hline 98 & 48 & PSEMEAN & 9 & 0 & 0 & 0 \\
\hline 99 & 222 & AGRSPI & $1,8,9$ & $\mathrm{~N}$ & $\mathbf{Y}$ & $\mathrm{N}$ \\
\hline 100 & 49 & PSEMEN & & 0 & 0 & 0 \\
\hline 101 & 41 & MTSHRUB & 3 & 0 & 0 & 0 \\
\hline 102 & 78 & MTSHRUR & & 0 & 0 & 0 \\
\hline 103 & 14 & ARTIRX & & $\mathbf{N}$ & $Y$ & $\mathbf{N}$ \\
\hline 104 & 52 & POABULL & & $\mathbf{Y}$ & $\mathrm{N}$ & $\mathbf{N}$ \\
\hline 105 & 65 & ARTTRX & 9 & $Y$ & $\mathbf{Y}$ & $\mathbf{N}$ \\
\hline 106 & 14 & PSEAEN & & 0 & 0 & 0 \\
\hline 107 & 45 & ERISPYI & 1,7 & 0 & 0 & 0 \\
\hline 108 & 86 & MTSHRUB & 1 & 0 & 0 & 0 \\
\hline 109 & 27 & PSEMAEN & & 0 & 0 & 0 \\
\hline 110 & 13 & PSEMAEN & & 0 & 0 & 0 \\
\hline 111 & 60 & ARTTRX & 9 & $Y$ & $\mathbf{Y}$ & $\mathbf{N}$ \\
\hline 112 & 355 & ARTTRX & 9 & $\mathrm{~N}$ & $\mathbf{Y}$ & $Y$ \\
\hline 113 & 36 & CRADOU & & 0 & 0 & 0 \\
\hline 114 & 82 & ARTIRX & 2 & $\mathbf{Y}$ & $\mathbf{N}$ & $\mathbf{N}$ \\
\hline 115 & 303 & ARTTRX & 9 & $\mathrm{~N}$ & $Y$ & $\mathbf{N}$ \\
\hline
\end{tabular}




\begin{tabular}{|c|c|c|c|c|c|c|}
\hline \multirow[t]{2}{*}{ Polygon " } & \multirow[t]{2}{*}{ Sizo } & \multirow[t]{2}{*}{ Cover type } & \multirow[t]{2}{*}{ Inchusions } & \multicolumn{3}{|c|}{ Ecological condition } \\
\hline & & & & Early seral & Mid-sonal & Late seral \\
\hline 116 & 22 & PSEMEN & & 0 & 0 & 0 \\
\hline 117 & 38 & MTSHRUB & & 0 & 0 & 0 \\
\hline 118 & 100 & ARTTRX & 4 & $\mathrm{~N}$ & $Y$ & $\mathrm{~N}$ \\
\hline 119 & 73 & MTSFIRUB & 1,10 & 0 & 0 & 0 \\
\hline 120 & 112 & ERISPH & $1,7,9$ & 0 & 0 & 0 \\
\hline 121 & 12 & PSEMRN & & 0 & 0 & 0 \\
\hline 122 & 45 & ERISPH & & $\mathbb{N}$ & $Y$ & $\mathrm{~N}$ \\
\hline 123 & 58 & PSEMEN & 1 & 0 & 0 & 0 \\
\hline 124 & 96 & ERISPY & & 0 & 0 & 0 \\
\hline 125 & 113 & MTSHRUB & 1,10 & 0 & 0 & 0 \\
\hline 126 & 41 & PSEMEAN & & 0 & 0 & 0 \\
\hline 127 & 48 & ARTTRX & 6,9 & 0 & 0 & 0 \\
\hline 128 & 236 & ERISPR & 3,9 & 0 & 0 & 0 \\
\hline 129 & 34. & MTSHRUB & & 0 & 0 & 0 \\
\hline 130 & 97 & MTSHRUB & & 0 & 0 & 0 \\
\hline 131 & 26 & CRADOU & & 0 & 0 & 0 \\
\hline 132 & 33 & ERISPR & & 0 & 0 & 0 \\
\hline 133 & 222 & ARTTRX & 6,9 & 0 & 0 & 0 \\
\hline 134 & 30 & MTSEIRUB & & 0 & 0 & 0 \\
\hline 135 & 11 & PSEMBN & & 0 & 0 & 0 \\
\hline 136 & 328 & ARTTRK & & 0 & 0 & 0 \\
\hline 137 & 140 & ARTTRX & 9 & $\mathbf{N}$ & $Y$ & $Y$ \\
\hline 138 & 55 & MTSHRUB & 1 & 0 & 0 & 0 \\
\hline 139 & \%4 & PSEMARN & & 0 & 0 & 0 \\
\hline 140 & 296 & POABUL & $3,8,9$ & $Y$ & $\mathbb{N}$ & $\mathbf{N}$ \\
\hline 141 & 325 & PSEAMEN & 3 & 0 & 0 & 0 \\
\hline 142 & 44 & ERISPH & 8 & 0 & 0 & 0 \\
\hline 143 & 32 & AGRSR & 8 & $Y$ & $\mathrm{Y}$ & $\mathrm{N}$ \\
\hline 144 & 279 & MTSFRUB & 1,10 & 0 & 0 & 0 \\
\hline
\end{tabular}




\begin{tabular}{|c|c|c|c|c|c|c|}
\hline Polygon & Size & Cover type & Inclusions & \multicolumn{3}{|c|}{ Ecological condition } \\
\hline & & & & Early seral & Mid-geral & Lato soral \\
\hline 145 & 49 & PSEMEN & 11 & 0 & 0 & 0 \\
\hline 146 & 182 & ERISPH & 1,8 & 0 & 0 & 0 \\
\hline 147 & 19 & MTSHRUB & 10 & 0 & 0 & 0 \\
\hline 148 & 37 & MTSHRUB & & 0 & 0 & 0 \\
\hline 149 & 131 & PSEMER & & 0 & 0 & 0 \\
\hline 150 & 196 & ARTTRX & 6 & $Y$ & $\mathrm{~N}$ & $\mathrm{~N}$ \\
\hline 151 & 58 & MTSHRUB & & 0 & 0 & 0 \\
\hline 152 & 298 & ARTTRX & 8,9 & $\mathrm{Y}$ & $\mathrm{Y}$ & $\mathrm{N}$ \\
\hline 153 & 295 & MTSKRUB & 1 & 0 & 0 & 0 \\
\hline 154 & 60 & ALNINC & & 0 & 0 & 0 \\
\hline
\end{tabular}




\section{Appendix 3}

Average relative cover and constancy values for six community types in the MMP Area.

Cover class code values used for Appendix 3 follow Bourgeron et al. (1991).

\begin{tabular}{lll} 
Code Class & & Midpoin \\
\hline 1 & $<1 \%$ & $0.5 \%$ \\
3 & $1 \%$ to $4.9 \%$ & $3 \%$ \\
10 & $5 \%$ to $14.9 \%$ & $10 \%$ \\
20 & $15 \%$ to $24.9 \%$ & $20 \%$ \\
30 & $25 \%$ to $34.9 \%$ & $30 \%$ \\
40 & $35 \%$ to $44.9 \%$ & $40 \%$ \\
50 & $45 \%$ to $54.9 \%$ & $50 \%$ \\
60 & $55 \%$ to $64.9 \%$ & $60 \%$ \\
70 & $65 \%$ to $74.9 \%$ & $70 \%$ \\
80 & $75 \%$ to $84.9 \%$ & $80 \%$ \\
90 & $85 \%$ to $94.9 \%$ & $90 \%$ \\
98 & $95 \%$ to $100 \%$ & $97.5 \%$
\end{tabular}

Ground cover attribute definitions also follow Bourgeron et al. (1991).

Bare soil - bare soil (particles < 1/16 in. dis.)

Gravel - gravel (particles $1 / 16$ to 3 in. dia.)

Rock - rock (particles > 3 in. dis.)

Litter - litter and duff (includes freshly-fallen leaves, needles, twigs, bark, fruits; duff is fermentation layer and humus layer)

Wood - wood (downed fragment $>1 / 4$ in. dila.)

Moss - moss (inchudes club mosess, and for purposes of this study, lichens as well)

Basal vegetation - basal vegetation (the ares occupied by root crowns and stems, not canopy cover)

Water - water (surface water) 

Average relative canopy cover and constancy (in parentheses) of ground cover attributes, lifo-clesses, und vascular plant species in six community types from the HMP Ares.

\begin{tabular}{|c|c|c|c|c|c|c|}
\hline & $\begin{array}{c}\text { Artars/ } \\
\text { Agripi } \\
n=3\end{array}$ & $\begin{array}{c}\text { Artarb/ } \\
\text { Agropi } \\
n=3\end{array}$ & $\begin{array}{c}\text { Erisph/ } \\
\text { Poesec } \\
n=3\end{array}$ & $\begin{array}{c}\text { Erithy/ } \\
\text { Posece } \\
n=3\end{array}$ & $\begin{array}{c}\text { Lomgn/ } \\
\text { Possec } \\
n=1\end{array}$ & $\begin{array}{l}\text { Cradou } \\
n=3\end{array}$ \\
\hline \multicolumn{7}{|l|}{ Ground Cover } \\
\hline bare soil & 60 & 70 & 20 & 10 & 10 & 20 \\
\hline gravel & 1 & 3 & 50 & 60 & 80 & 3 \\
\hline rock & 1 & 1 & 30 & 30 & 10 & 3 \\
\hline litter & 30 & 20 & 3 & 3 & 3 & 60 \\
\hline wood & 1 & 3 & 1 & 1 & 0 & 3 \\
\hline moss & 3 & 3 & 1 & 1 & 1 & 1 \\
\hline baral vegetation & 10 & 10 & 3 & 3 & 3 & 10 \\
\hline water & 0 & 0 & 0 & 0 & 0 & 10 \\
\hline \multicolumn{7}{|l|}{ Lifeclens cover } \\
\hline Shrubs & 30 & 20 & 10 & 3 & 0 & 90 \\
\hline Forbs & 20 & 10 & 10. & 3 & 20 & 10 \\
\hline Graminoids & 30 & 30 & 10 & 3 & 10 & 20 \\
\hline \multicolumn{7}{|l|}{ Shrubs } \\
\hline Amelenchis alnifolin & & & & & & $1(60)$ \\
\hline Arteminia srbuscula & & $20(100)$ & & & & \\
\hline $\begin{array}{l}\text { Artemigin tridentates } \\
\text { xericensis }\end{array}$ & $20(100)$ & & & & & " \\
\hline Chrysothamnus nsuseosus & $1(33)$ & & & & & \\
\hline Cratnegus douglanii & & & & & & $80(100)$ \\
\hline Eriogonum elntum & $1(33)$ & & & & & \\
\hline Eriogonum heracleoides & $3(60)$ & & & & & \\
\hline $\begin{array}{l}\text { Eriogonum } \\
\text { spheerocephalvas }\end{array}$ & & & $10(100)$ & & & \\
\hline Eriogonum thymoidse & & & $1(66)$ & $3(100)$ & & \\
\hline Prunus virginiess & & & & & & $3(100)$ \\
\hline Purshis tridentan & $10(100)$ & $3(66)$ & & & & \\
\hline Ribes aureum & & & & & & $3(100)$ \\
\hline Roses woodsit & & & & & & $10(100)$ \\
\hline Salix geyerians & & & & & & $20(69)$ \\
\hline
\end{tabular}




\begin{tabular}{|c|c|c|c|c|c|c|}
\hline & $\begin{array}{l}\text { Arturd/ } \\
\text { Agrespi } \\
n=3\end{array}$ & $\begin{array}{c}\text { Artarb/ } \\
\text { Agreppi } \\
n=3\end{array}$ & $\begin{array}{c}\text { Erieph/ } \\
\text { Poenece } \\
\mathrm{n}=3\end{array}$ & $\begin{array}{l}\text { Erithyl } \\
\text { Poasec } \\
n=3\end{array}$ & $\begin{array}{l}\text { Lomgral } \\
\text { Posecec } \\
n=1\end{array}$ & $\begin{array}{l}\text { Cnadou } \\
n=3\end{array}$ \\
\hline Symphoricarpos albus & & & & & & $1(33)$ \\
\hline \multicolumn{7}{|l|}{ Forbs } \\
\hline Achilles millefolium & $3(100)$ & $3(100)$ & $1(33)$ & & & $1(100)$ \\
\hline Agoseris glaucs & $1(33)$ & $1(33)$ & & & & \\
\hline Allium acuminstum & & $1(33)$ & $1(66)$ & & $1(100)$ & \\
\hline Allium pervim & & & $1(66)$ & $1(66)$ & & \\
\hline Antennaris flagellaris & & & & $1(33)$ & & \\
\hline Antennaris luzulins & & $10(69)$ & & & & \\
\hline Arabis aparsiflore & & $1(33)$ & & & & \\
\hline Anabis ap. & & $1(33)$ & $1(33)$ & $1(33)$ & & \\
\hline Arenarin congeatas & & $1(66)$ & & & & \\
\hline Artemisis ludovicians & & & & & & $1(33)$ \\
\hline Balamorhizs hookert & & $1(33)$ & $1(33)$ & $1(33)$ & $3(100)$ & \\
\hline Balumorthiza segitrata & $10(100)$ & $3(3)$ & & & & \\
\hline Brodinen douglanii & $1(33)$ & $1(33)$ & & & & \\
\hline Celochorass eurycerpus & $1(60)$ & $1(100)$ & & & & \\
\hline Castilleje chromoss & & $1(33)$ & & & & \\
\hline Cersatium ep. & & $1(33)$ & & & & \\
\hline Clarkis pulchella & $3(33)$ & & & & & \\
\hline Collomis linearis & $1(33)$ & & $1(33)$ & & & \\
\hline Commandrs umbellabs & $1(33)$ & & & & & \\
\hline Crepis occidentalis & $1(100)$ & $1(33)$ & & & & \\
\hline Epilobium glebberimum & & & & & & $3(33)$ \\
\hline Epilobium paniculatuman & & $1(100)$ & & & & \\
\hline Fragaria vesea & & & & & & $1(33)$ \\
\hline Galium aparine & $1(33)$ & $1(33)$ & & & & $1(33)$ \\
\hline Geum macrophyllum & & & & & & $1(33)$ \\
\hline Heplopeppus lanuginosus & & $1(33)$ & & & . & \\
\hline Hydrophylluss ceppitanum & $1(33)$ & & & & & \\
\hline Lometium grayi & & & $3(60)$ & & $20(100)$ & \\
\hline Lomstium leptocarpum & & $1(33)$ & $3(69)$ & $3(60)$ & & \\
\hline
\end{tabular}




\begin{tabular}{|c|c|c|c|c|c|c|}
\hline & $\begin{array}{c}\text { Artural } \\
\text { Agrapi } \\
n=3\end{array}$ & $\begin{array}{c}\text { Artarb/ } \\
\text { Agropi } \\
n=3\end{array}$ & $\begin{array}{c}\text { Erisph/ } \\
\text { Poasec } \\
n=3\end{array}$ & $\begin{array}{c}\text { Erithy/ } \\
\text { Possec } \\
n=3\end{array}$ & $\begin{array}{c}\text { Lomgral } \\
\text { Poasec } \\
n=1\end{array}$ & $\begin{array}{c}\text { Cradou } \\
n=3\end{array}$ \\
\hline Lomntium nudicauls & $3(33)$ & $3(66)$ & & $1(33)$ & & $1(33)$ \\
\hline Lotus purshiana & & $3(33)$ & & & & \\
\hline Lupinus lexiflorus & $3(66)$ & $1(33)$ & & & & $1(33)$ \\
\hline Melilotus officinale & & & & & & 3 (33) \\
\hline Menthe arvensis & & & & & & 1 (33) \\
\hline Microseris troximoides & $1(33)$ & & $1(100)$ & $1(100)$ & $1(100)$ & \\
\hline Mimulus guttacus & & & & & & $1(33)$ \\
\hline Montia perfolinta & & $1(33)$ & & & & \\
\hline Myosotis discolor & & 1 (33) & & & & \\
\hline Naverettin intertexil & & $3(100)$ & & & & \\
\hline Nepeta catars & & & & & & 1 (33) \\
\hline Orobanche fasciculate & & & & $1(33)$ & & \\
\hline Osmorhiza chileanis & & & . & & & $3(60)$ \\
\hline Penstemon gairdneri & & $1(66)$ & $1(33)$ & & & \\
\hline Penatemon glandulosus & $1(33)$ & & & & & \\
\hline Perideridia bolanderi & & & & & & $1(60)$ \\
\hline Phacelis heterophylls & $1(60)$ & & & & & \\
\hline Phecelin linearis & $1(33)$ & & & & & \\
\hline Phiox longifolia & $1(33)$ & & & & & \\
\hline $\begin{array}{l}\text { Phoenocaulis } \\
\text { cherianthoides }\end{array}$ & & & & $1(60)$ & & \\
\hline Pls giobothrys scouleri & & $1(60)$ & & & & \\
\hline Polygonum dougleaii & & & $3(100)$ & $3(100)$ & $3(100)$ & \\
\hline Polygonum kelloggii & & $1(66)$ & & & & \\
\hline Potencilla groili & & & & & & $1(33)$ \\
\hline Rumex criepus & & & & & & $1(33)$ \\
\hline Senecio foetidus & & & & & & $1(33)$ \\
\hline Senecio integgrimus & $1(60)$ & $1(66)$ & & & & \\
\hline Senecio triangularis & & & & & & 1 (33) \\
\hline Siduloen oregruns & 1 (33) & $3(33)$ & & & & $1(33)$ \\
\hline Terescacum officinale & & & & & & $1(60)$ \\
\hline
\end{tabular}




\begin{tabular}{|c|c|c|c|c|c|c|}
\hline & $\begin{array}{c}\text { Artund } \\
\text { A grapi } \\
n=3\end{array}$ & $\begin{array}{l}\text { Arrarb/ } \\
\text { Agrupi } \\
n=3\end{array}$ & $\begin{array}{l}\text { Erisph/ } \\
\text { Poesec } \\
n=3\end{array}$ & $\begin{array}{c}\text { Erithyl } \\
\text { Poeses } \\
n=3\end{array}$ & $\begin{array}{c}\text { Lomgeal } \\
\text { Possec } \\
n=1\end{array}$ & $\begin{array}{l}\text { Cradous } \\
n=3\end{array}$ \\
\hline Tregopogon dubius & $1(66)$ & $1(33)$ & $1(66)$ & $1(33)$ & & $1(33)$ \\
\hline Trifolium longipes & & & & & & $1(33)$ \\
\hline Trifolium macrocephalun & & & $3(66)$ & $1(33)$ & $1(100)$ & \\
\hline Veroencum thaspes & & & & & & $1(33)$ \\
\hline Vicis americansa & & & & & & $1(33)$ \\
\hline Viols ep. & & & & & & 1 (33) \\
\hline Wyethin amplexicaulis & & & & & & $1(33)$ \\
\hline \multicolumn{7}{|l|}{ Gramisoidls } \\
\hline Agropyron spicatum & $20(100)$ & $20(100)$ & & & $1(100)$ & \\
\hline Alopocures roqualin & & & & & & $1(33)$ \\
\hline Bromus briaziformis & $1(33)$ & & & $1(66)$ & & \\
\hline Bromu japonicus & $1(60)$ & & $1(33)$ & $1(60)$ & $1(100)$ & \\
\hline Bromue mollis & $1(33)$ & & $1(33)$ & $1(33)$ & & \\
\hline Bromus toctorurn & $1(33)$ & & $1(33)$ & $1(33)$ & $1(100)$ & \\
\hline Carex microptera & & & & & & $3(33)$ \\
\hline Danthorias unispicets & & $1(33)$ & & & & \\
\hline Elymus giavers & & & & & & $3(66)$ \\
\hline Fertuce bromoides & $1(33)$ & & $1(33)$ & & & \\
\hline Glyceria "p. & & & & & & $1(330$ \\
\hline Koelaria crimtons & $3(33)$ & & & & & \\
\hline Melica bulbona & $3(33)$ & $1(33)$ & & & & \\
\hline Pos bulbosa & $10(66)$ & $10(100)$ & $3(100)$ & $3(100)$ & $3(100)$ & $20(33)$ \\
\hline Pos prebeasis & & & & & & $10(100)$ \\
\hline Pos secundis & $1(60)$ & $3(100)$ & $10(100)$ & $1(100)$ & $3(100)$ & \\
\hline Scippus microcurpens & & & & & & $3(60)$ \\
\hline Sitanion hystris & $1(33)$ & $3(33)$ & $3(60)$ & $1(60)$ & $1(100)$ & \\
\hline Stipa lectermanraï & $I(33)$ & & & & & \\
\hline Stipe occidentalis & $3(33)$ & & & & & \\
\hline
\end{tabular}




\section{Appendix 4 \\ Location of vegetation sample plots in the HMP Ares.}

Map 1. Plots 96MM001 - 004. Portion of Midvale Hill 7.5' U.S.G.S. topographic quadrangle.

Map 2. Plots 96MM005 - 009; 016. Portion of Mann Creek 7.5' U.S.G.S. topographic quadrangle.

Map 3. Plots 96MM010 - 012. Portion of Midvale Hill 7.5' U.S.G.S. topographic quadrangle.

Map 4. Plot 96MM014. Portion of Midvale Hill 7.5' U.S.G.S. topographic quadrangle.

Map 5. Plots 96MM013 and 015. Portion of Hopper Creek 7.5' U.S.G.S. topographic quadrangle. 
.

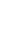

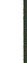




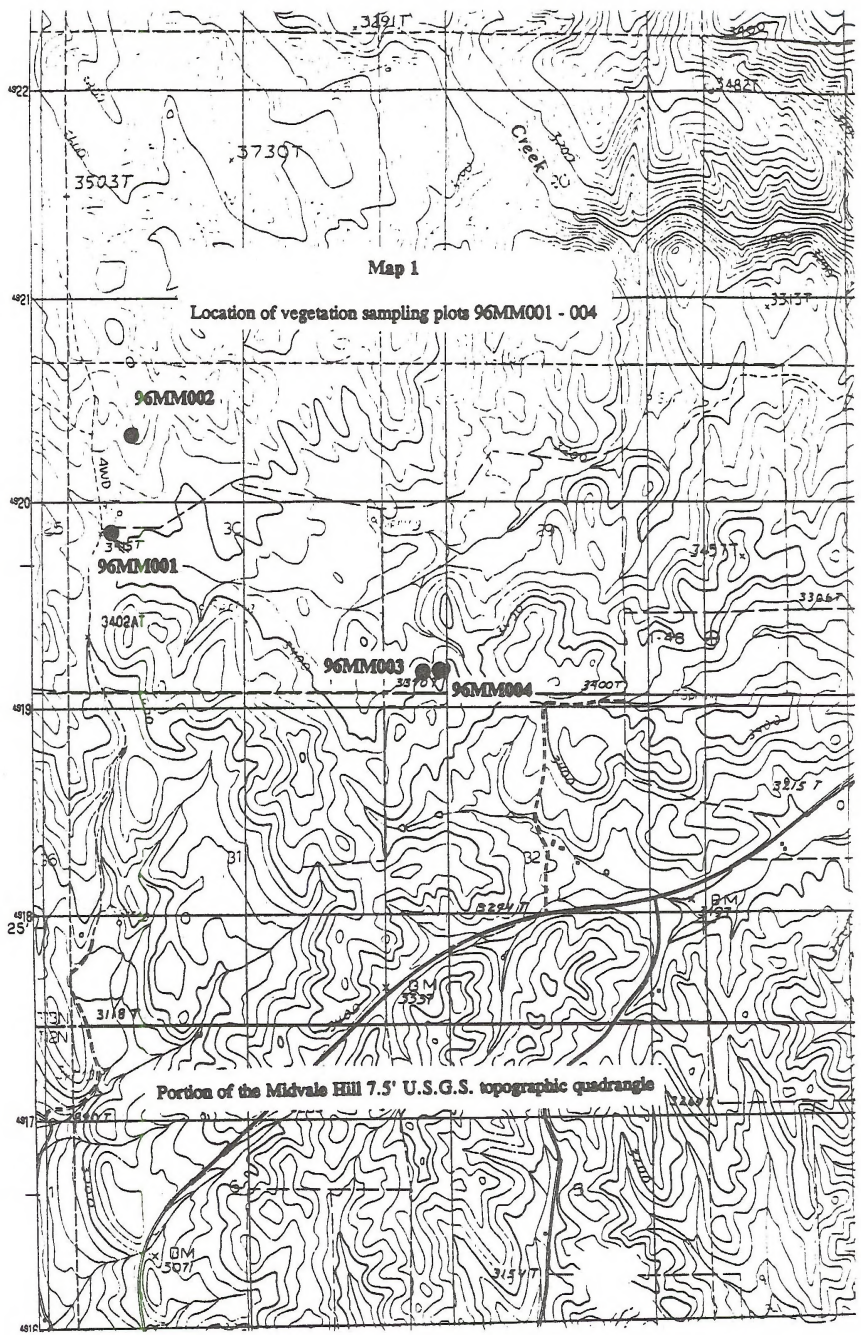




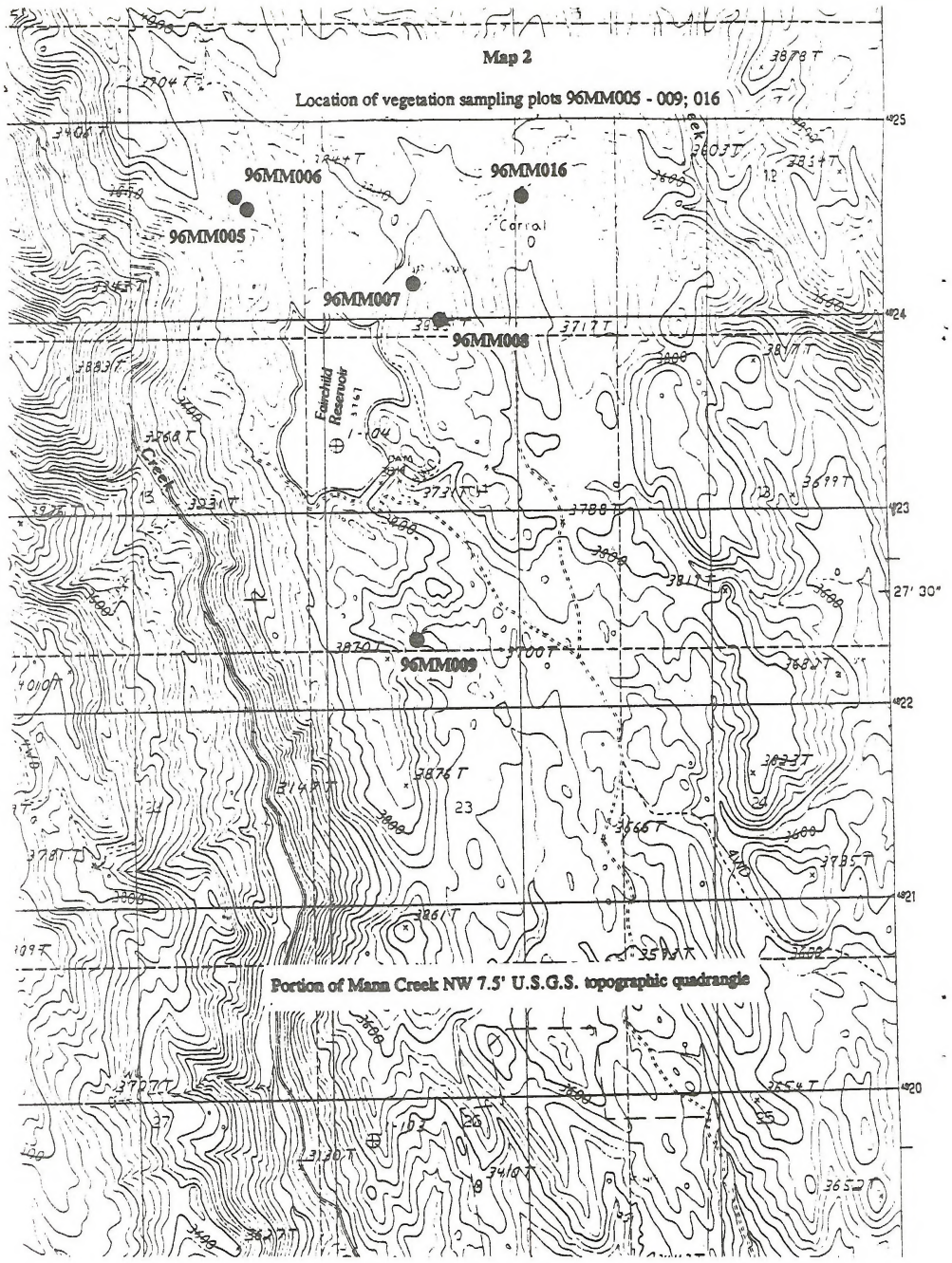




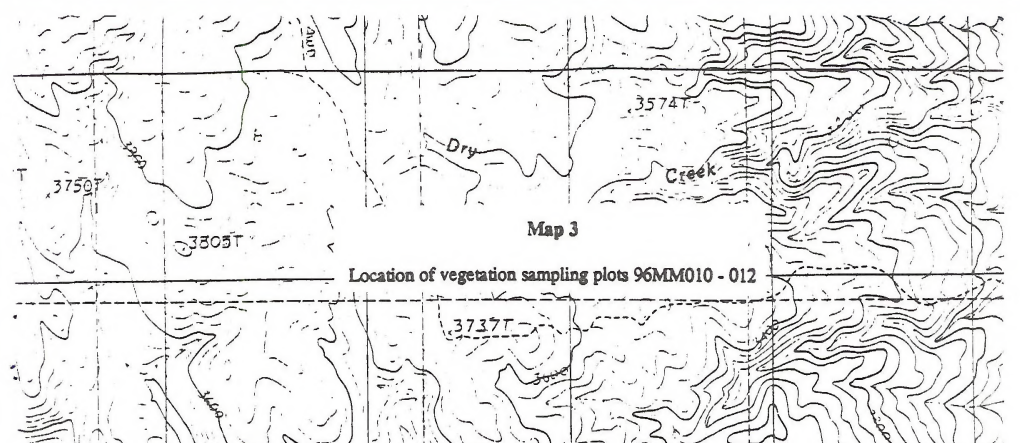

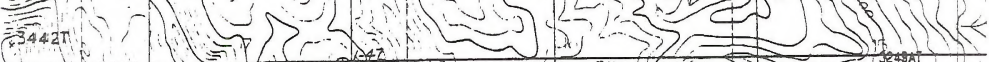
(2.

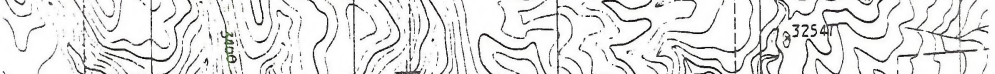
2 . - 1 ( 2. $-1 . \cdots, \ldots$ (1)

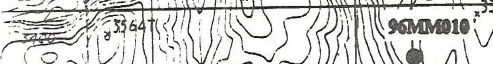
(2) $\therefore$ (1)

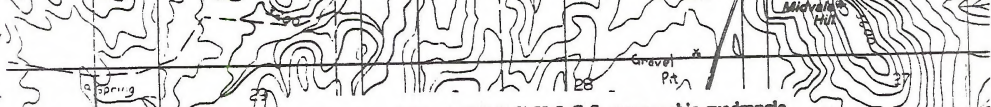

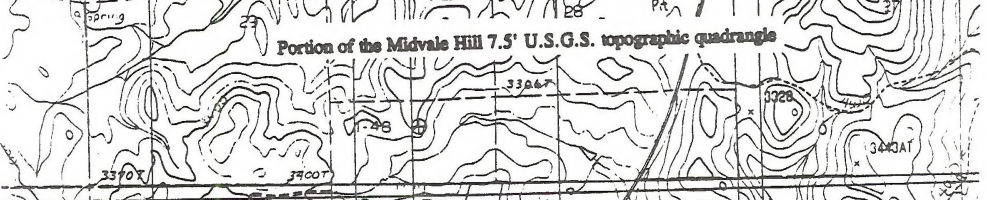

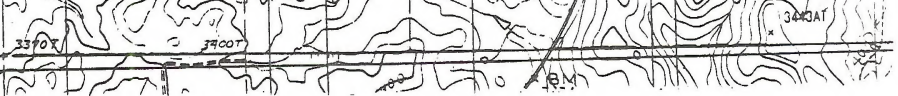




\section{DEPARTMENT OF THE INTERIOR}

\section{GEOLOGICAL SURVEY}

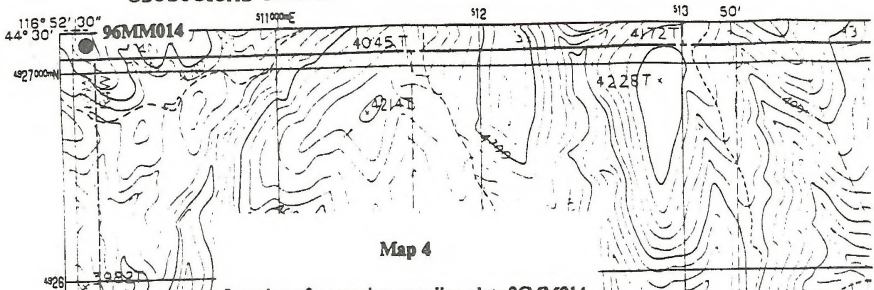

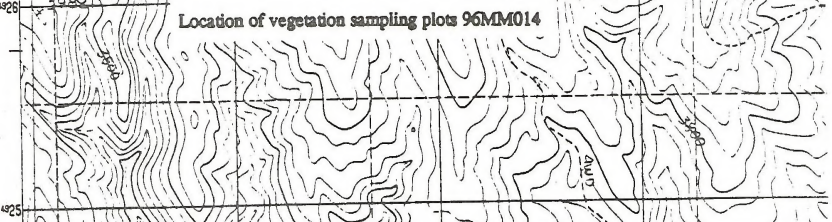

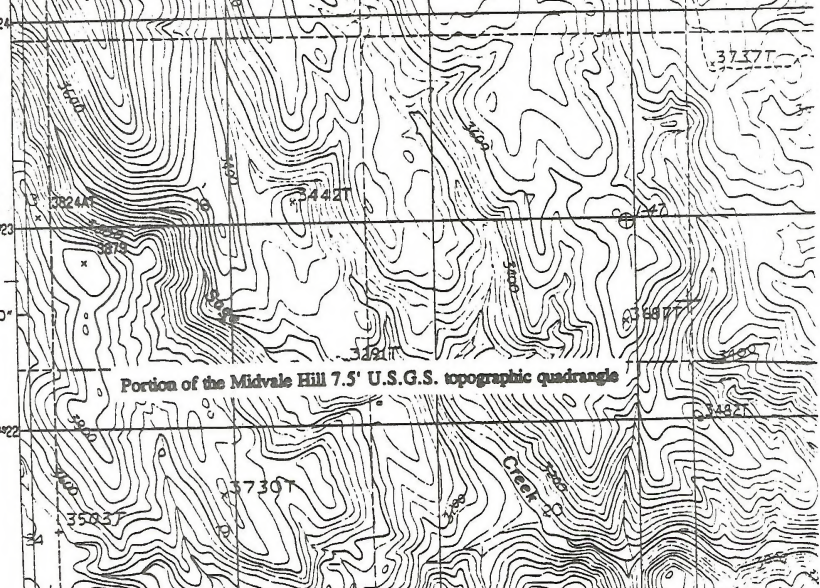




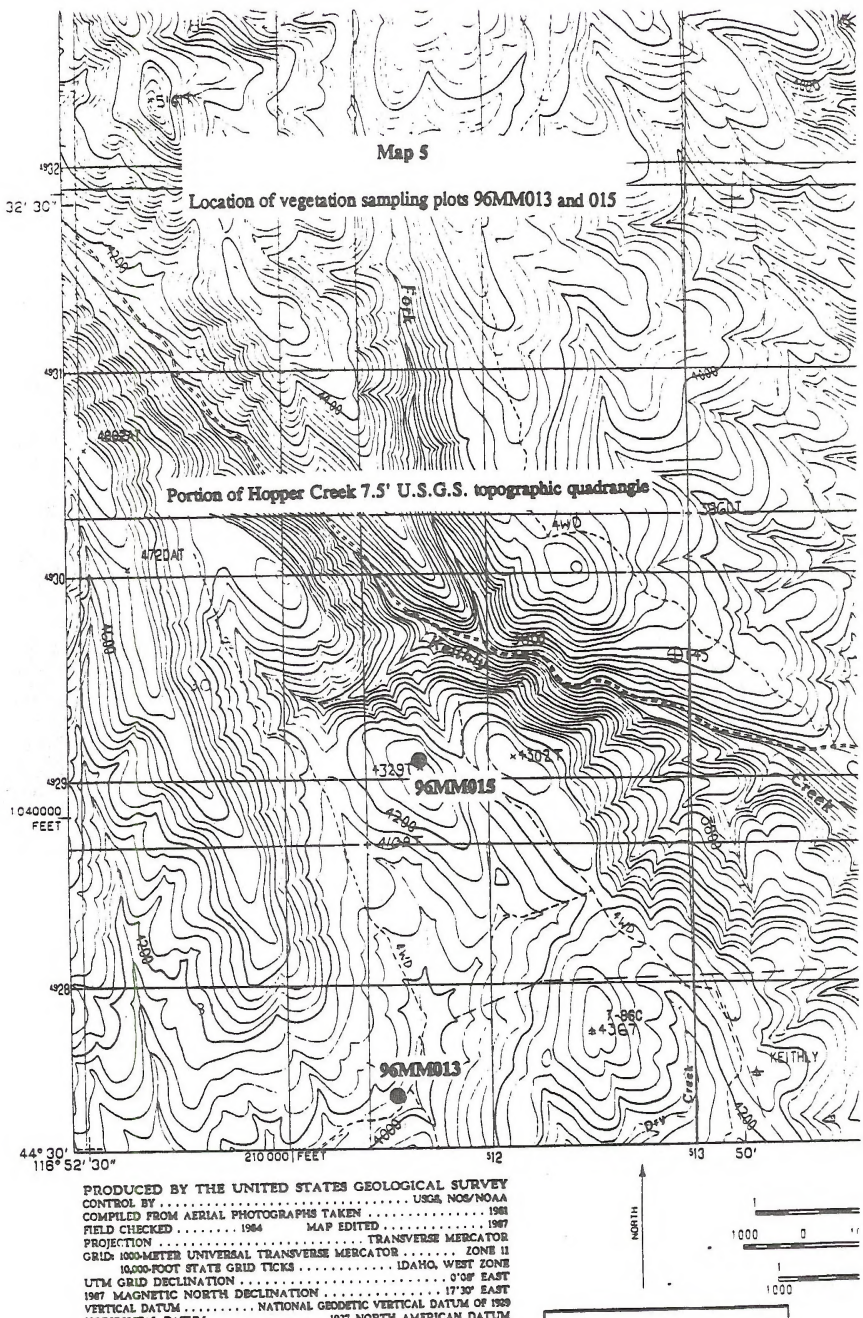


-

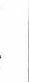


Appendix 5

Westem Heritage Task Force plot forms II and III. 



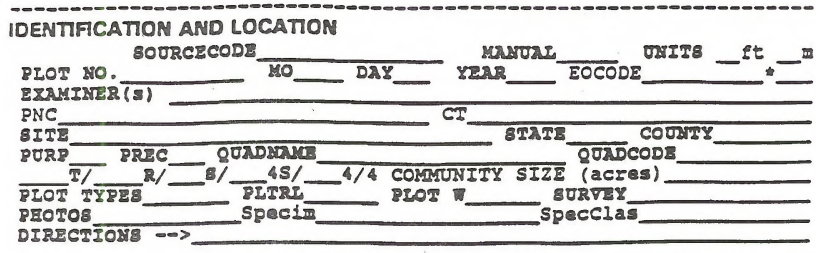

--

CONSERVATION RAMKING
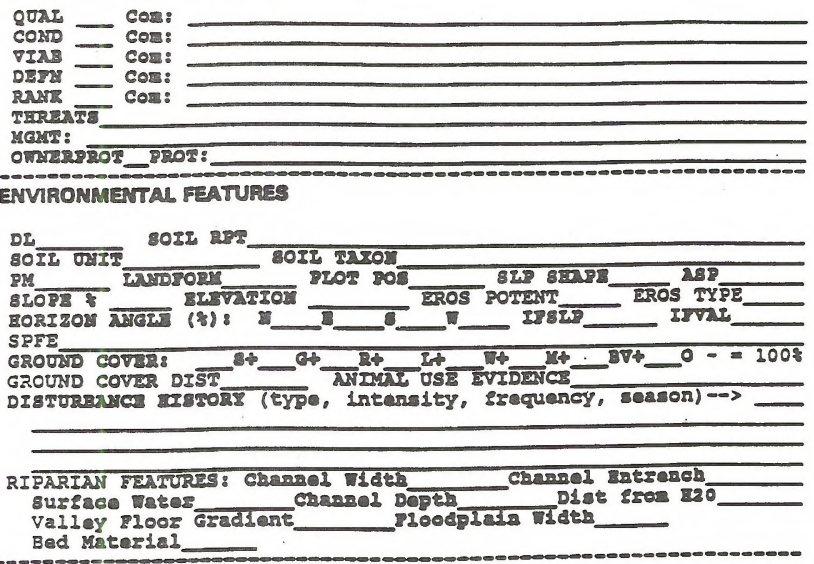
GENERAL STT DESCRPTION (Iandscape condition and adjacent ct's) 


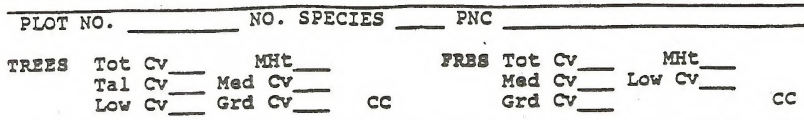
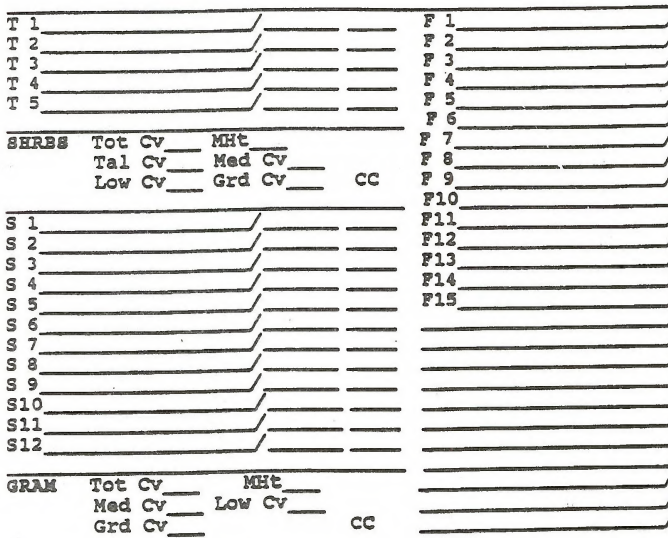

F10
F12
F12

ह13

18

?1
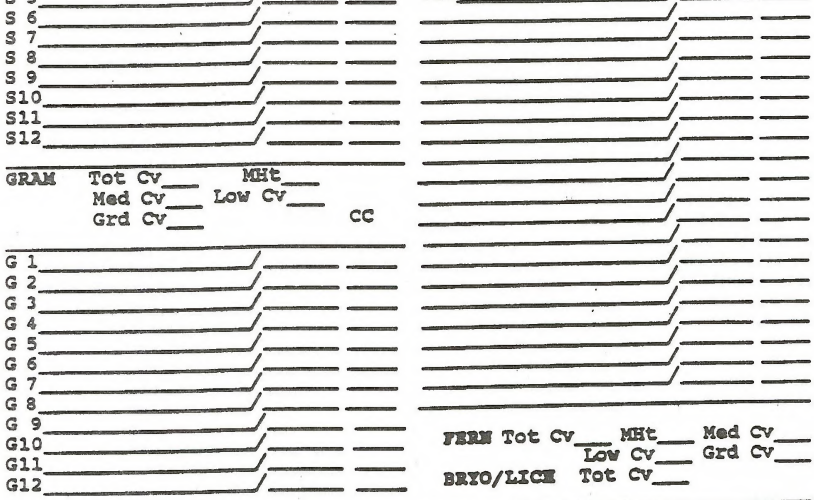

COMMENTS (EODATA) $\rightarrow$ 
Appendix 6

Element Occurrence Records for Peraphyllum ramosissimum in the HMP Area. 
: 
PERAPHYLIUM RAMOSISSIMUM

SQUAWAPPLE

Occurrence Number: 005

Survey Site Name: HIXON SHARPTAIL PRESERVE

County: Washington

USGS quadrangle: MANN CREEK NW

Latiude: $442728 \mathrm{~N}$ Longitude: $1165415 \mathrm{~W}$

TOWNRANGE: SECTION:

$013 \mathrm{NOOSW} .14$

\section{MERIDIAN: TRSNOTE:}

BO SEASW4

Location:

The occurrence is located about 0.5 mile south of Fairchild Reservoir. The reservoir is located approximately 14 miles NNE of Weiser, and is accessed via an unmarked, narrow, 4-wheel drive road that leads off the Mann Creek road about 0.5 mile south of the Adams Creek road.

Survey Date: 1996-05 First Observed: $1983 \quad$ Last Observed: 1996-05

EORANK: B

Population Data:

1983: Plants common. 1989: Ca 200-300 individuals in fruit; good overall site

quality. Observation by Roger Rosentreter, Idaho State BLM. 1996: Ca 200-300 individuals observed by Bob Moseley, Idabo CDC.

Habitat Description:

$\mathrm{OnS}$ and W-facing slopes of popcorn-textured heavy clay soils; $25 \%$ slope. Artemisia

arbuscula/Agropyron spicatum community with mixed shrubs. Associated with Amelanchier alnifolia and Agropyron spicatum.

Minimum Elevation: 3680 feet Maximum Elevation: 3800 feet Size: 5 AC

Land Owner/Manager: Bureau of Land Management; The Nature Conservancy

Ownership Comments: Lower Snake River District BLM, Cascade RA, and The Nature Conservancy's Hixon Sarptail Preserve.

Comments:

Protection Comments: Occurrence is located within the "Hixon Pasure" exclosure, a part of the Hixon Columbian sharp-tailed grouse Habitat Management Plan Area. A portion of the occurrences is contained within TNC's Hixon Sharptail Preserve.

Management Comments:

Specimens:

C. A. Wellner 2831 (DD) - collection label reads " 16 air miles NNE of Weiser, tributary of Sage Creek". 
PERAPHYLLUM RAMOSISSIMUM

SQUAWAPPLE

Occurrence Number: 006

Survey Site Name: DEER CREEK

County: Washington

USGS quadrangle: MANN CREEK NW

Latitude: $442614 \mathrm{~N}$ Longitude: $1165244 \mathrm{~W}$

TOWNRANGE: SECTION: MERIDIAN: TRSNOTE:

$\begin{array}{llll}013 N 005 W & 25 & B O & \text { NEA }\end{array}$

Location:

Approximately 15 miles NNE of Weiser. Occurrence area is accessible vis foot from the Deer Creek road. This road is a spur off of the Mann Creek road.

Survey Date: First Observed: 1980 'S Last Observed: 1980 's

EORANK:

Population Data:

1980's: No population information. Listed as a lonown site by Rosentreter (1980).

Habitat Description:

No information available.

Minimum Elevation: 3550 feet Maximum Elevation: feet Size:

Land Owner/Manager:

Lower Snale River District BLM, Cascade RA.

Ownership Comments:

May also be on nearby private land.

Comments:

Protection Coramente:

Located within the Hiron Columbian sharp-ailed grouse Habitat Management Plan Area.

Managemeat Commenta:

Specimens: 
PERAPHYLIUM RAMOSISSIMUM

SQUAWAPPLE

Occurrence Number: 007

Survey Site Name: SOUTH OF FAIRCHILD RESERVOIR

County: Washington

USGS quadrangle: MANN CREEK NW

Latiude: $442637 \mathrm{~N}$ Longitude: $1165405 \mathrm{~W}$

$\begin{array}{lccc}\text { TOWNRANGE: } & \text { SECTION: } & \text { MERIDIAN: } & \text { TRSNOTE: } \\ 013 \mathrm{~N} 005 \mathrm{~W} & 23 & \text { BO } & \text { SEA } \\ \text { 013N005W } & 26 & \text { BO } & \text { NEA }\end{array}$

Location: Approximately 14 miles NNE of Weiser, and 1.2 and 1.8 miles south of Fairchild Reservoir. Access is via foot from the end of the Deer Creek Road. This road is a spur off the Mann Creek Road.

Survey Date: $19960530 \quad$ First Observed: 1960-07-05 Last Observed: 1996-05-30

EORANK: C

Population Dat: 1960-1983: No dat from several collections. 1996: Two subpopulations. The northern subpopulation is comprised of about ten individuals. The southern subpopulation contains about 50 plants; with about 40 in a dense clump and 10 others widely scattered. All are severely hedged and less than three feet tall. Vigor is assessed as poor. All fruits aborted. Observation by Bob Moseley, Idaho CDC.

Habitat Description: Xeric sagebrush/bluebunch wheatgrass babitat type in mid-seral condition. Bulbous bluegrass and cheatgrass are common. Other associates include Sambucus cerulea. Purshla tridentata, Agropyron spicatum, Balsamorhize sagirtara, Lupinus laxiforus, Achillea millefolium, and Lomatium dissecrum. Dry, south-facing slope hillside.

Minimum Elevation: 3600 feet Maximum Elevation: 3650 feet Size: 2 ACRES

Land Owner/Manager: Bureau of Land Management; private land

Ownership Comments: Lower Smalne River District BLM, Cascade RA; private land.

Comments: Bob Mosely clarified the location of this occurrence during field work conducted for the Hixon Columbian sharp-tailed grouse Habitat Management Plan Area vegetation map project.

Protection Comments: Located within the Hixon Columbian sharp-tailed grouse Habitat Management Plan Area.

Management Couments:

Specimens:

V. Saab 194 (CIC) - collected 9/1/83; T. Stevens 126 (CIC) - collected 7/5/60; R. D. Bratz s.n. (CIC) collected $5 / 5 / 61$. 



\section{Appendix 7}

Location of sharp-tailed grouse observations in the HMP Area.

Map 1. Portion of Midvale Hill 7.5' U.S.G.S. topographic quadrangle.

Map 2. Portion of Mann Creek NW 7.5' U.S.G.S. topographic quadrangle. 

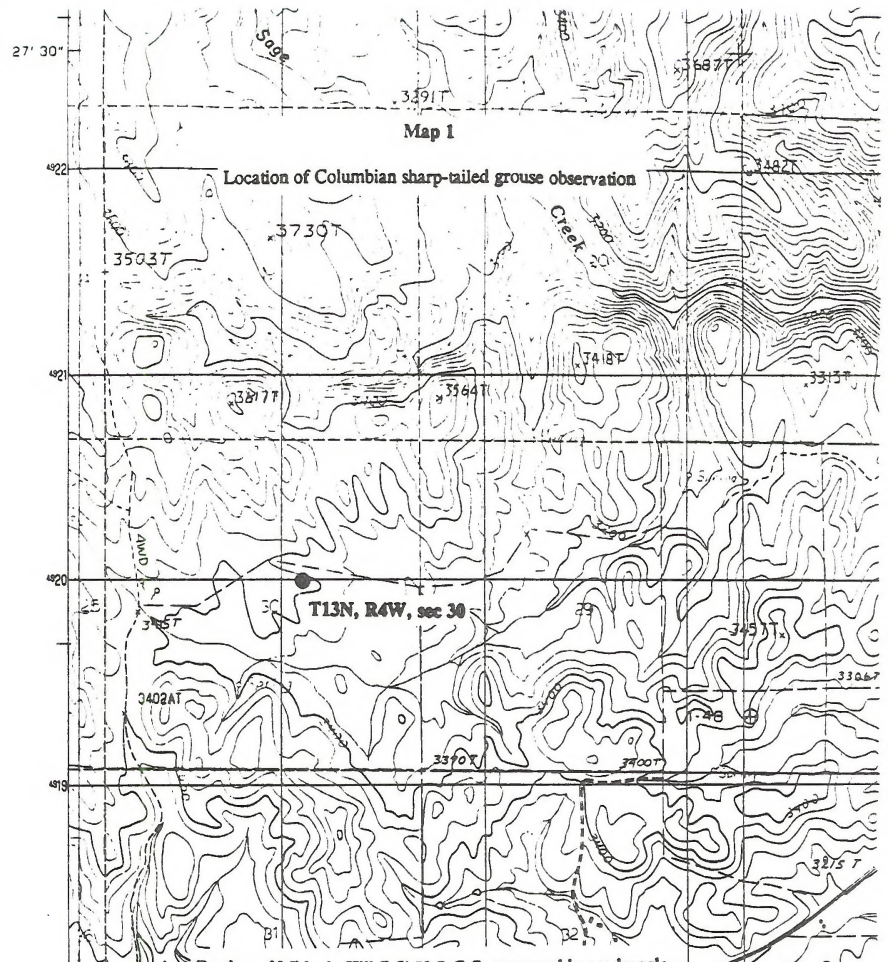
25.

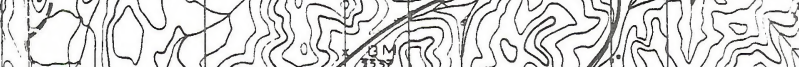

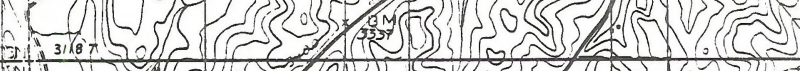
( 


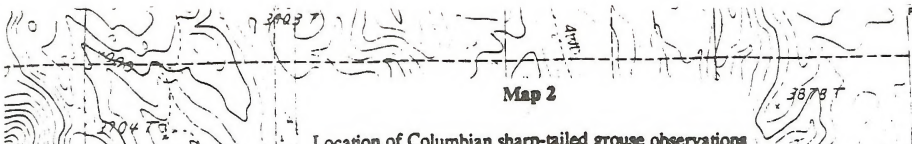

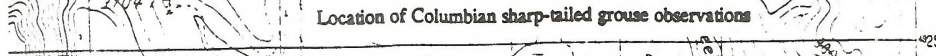

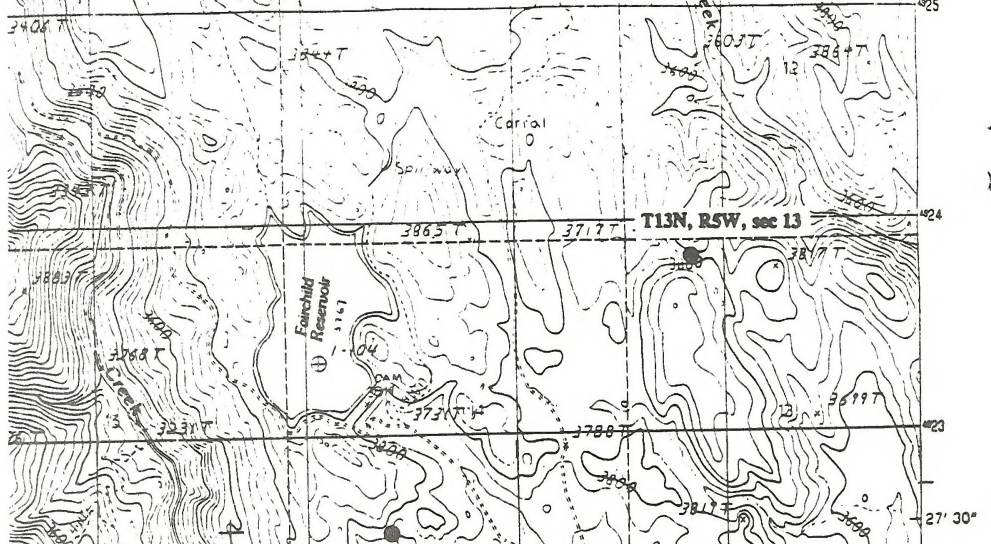

Non,

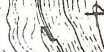

T13N, RS, sae 14

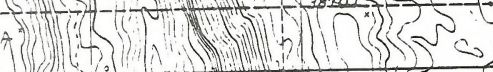

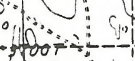

$1_{1} 2$ 1

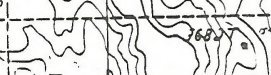

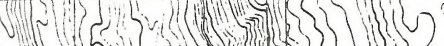

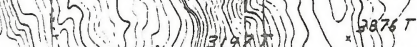

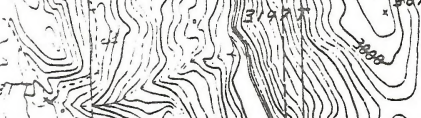

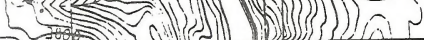

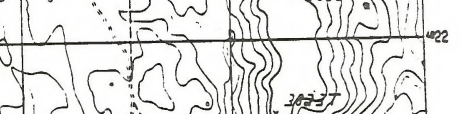

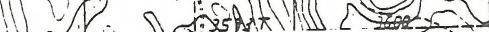

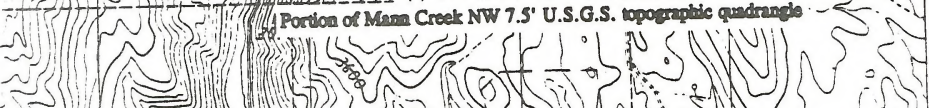

C)

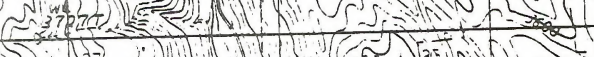

(1) 37 [5)

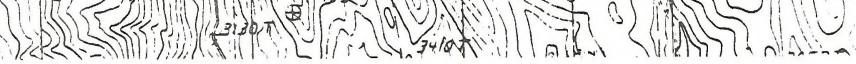


Submitted by:

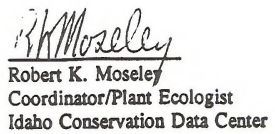

Approved by:

IDAHO DEPARTMENT OF FISH AND GAME

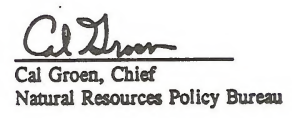





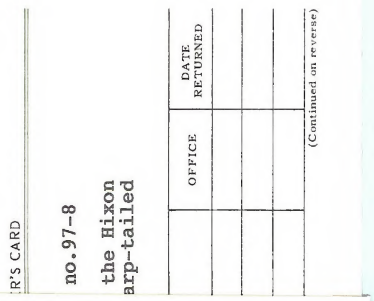

QL 84.2 .I.352 no.97-8

88055213

Vegetation of the Hixon Columbian sharp-tailed

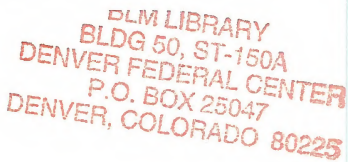




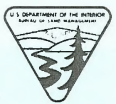

Bureau of Land Management Idaho State Office 1387 S. Vinnell Way

Boise, Idaho 83709

BLM/LD/PT.97/010+1150 